\title{
FARINHA DE OSSOS CALCINADA Alternativa tecnológica para calagem e fosfatagem em solos tropicais?
}

Elvino Ferreira

Klaus Casaro Saturnino Thais Rabelo dos Santos (Orgs.)

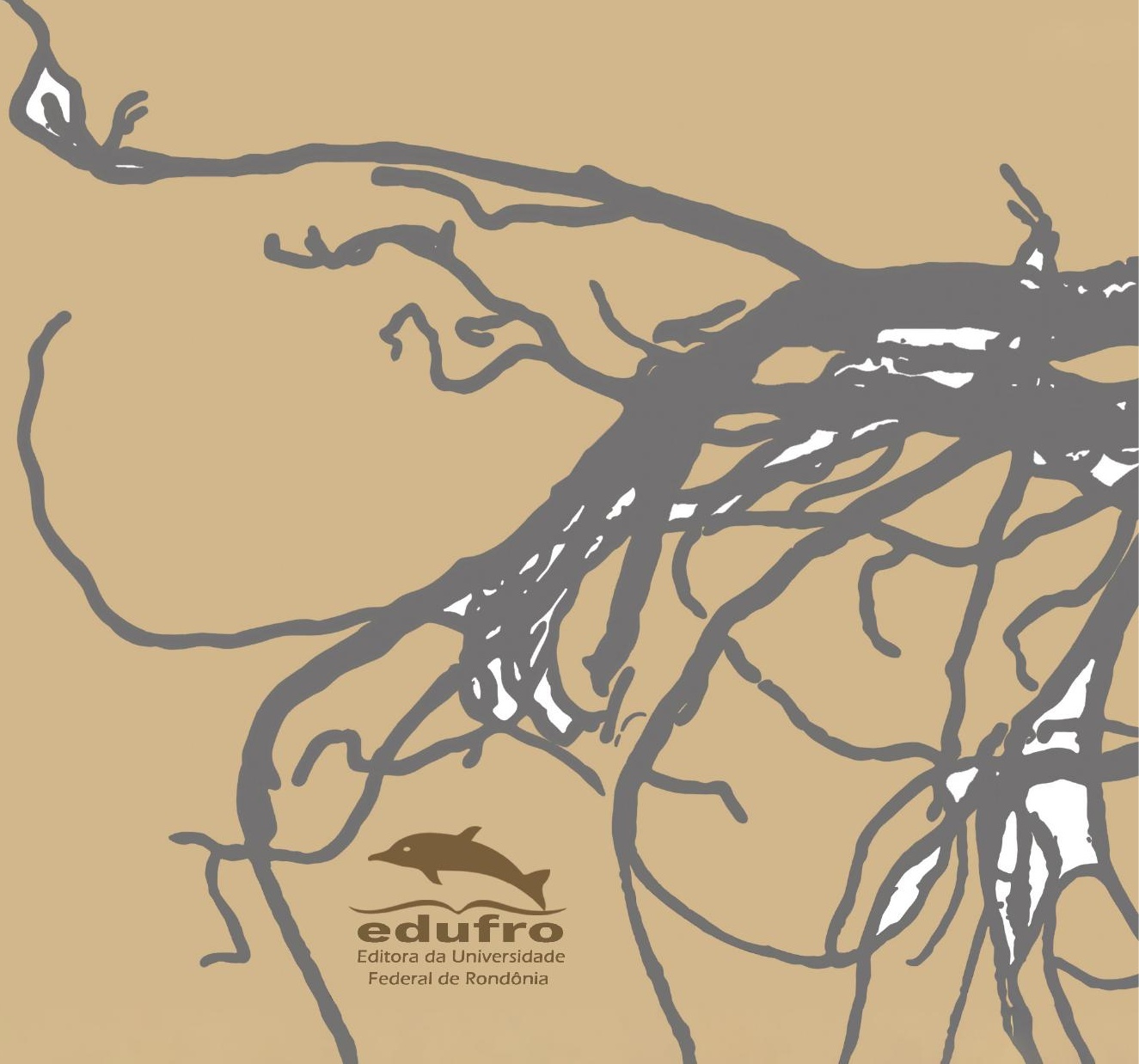




\section{Farinha de Ossos Calcinada: Alternativa tecnológica para calagem e fosfatagem em solos tropicais?}


Reitor Ari Miguel Teixeira Ott

Vice-Reitor José Juliano Cedaro

EDITORA DA UNIVERSIDADE FEDERAL DE RONDÔNIA

$\begin{array}{ll} & \text { CONSELHO EDITORIAL } \\ \text { Presidente } & \text { Lou-Ann Kleppa } \\ & \text { Ariana Boaventura Pereira } \\ \text { Carlos Alexandre Trubiliano } & \text { Eliane Gemaque Gomes Barros } \\ & \text { Gean Carla Silva Sganderla } \\ \text { Leandro Soares Moreira Dill } & \text { Márcio Secco } \\ & \text { Marli Lúcia Tonatto Zibetti } \\ & \text { Pedro Ivo Silveira Andretta } \\ & \text { Ricardo Gilson da Costa Silva } \\ & \text { Xênia de Castro Barbosa }\end{array}$

Editora Filiada
Edufro - Editora da Universidade Federal de Rondônia BR 364, Km 9,5
Campus Unir
76801-059 - Porto Velho - RO
Tel.: (69) 2182-2175
www.edufro.unir.br edufro@unir.br




\section{Farinha de Ossos Calcinada: Alternativa tecnológica para calagem e fosfatagem em solos tropicais?}

Elvino Ferreira

Klaus Casaro Saturnino

Thais Rabelo dos Santos

(Organizadores)

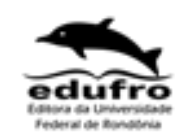

Porto Velho

2020 
(C) 2020 by Elvino Ferreira, Klaus Casaro Saturnino, Thais Rabelo dos Santos (Organizadores) Esta obra é publicada sob a Licença Creative Commons Atribuição-Não

Comercial 4.0 Internacional.

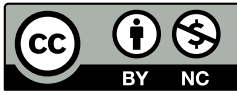

Capa:

Jôsy Monteiro Alves

Revisão:

Dra. Jeane Mari Spera

Projeto gráfico:

Edufro - Editora da Universidade Federal de Rondônia

Diagramação:

Guilherme André de Campos

Impressão e acabamento:

Seike \& Monteiro Editora

Dados Internacionais de Catalogação na Publicação

Fundação Universidade Federal de Rondônia (UNIR)

Ficha Catalográfica elaborada pela Biblioteca Central da UNIR

F981 Fundação Universidade Federal de Rondônia.

Farinha de ossos calcinada: alternativa tecnológica para calagem e fosfatagem em solos tropicais? / organização Elvino Ferreira, Klaus Casaro Saturnino, Thais Rabelo dos Santos. - Porto Velho, RO: EDUFRO, 2020.

123 p.; il.

ISBN: 978-65-87539-17-1 (físico)

ISBN: 978-65-87539-08-9 (digital)

1. Resíduos. 2. Sustentabilidade. 3. Inovação. 4. Agroecossistemas. I. Ferreira, Elvino. II. Saturnino, Klaus Casaro. III. Santos, Thais Rabelo dos. IV. Fundação Universidade Federal de Rondônia.

CDU 638.1(81) 
"Se você sempre fez algo da mesma maneira, provavelmente está errado."

Charles Kettering 

Aos eternos estudantes! 



\section{PREFÁCIO}

Uma das mais belas características que a ciência pode apresentar ao mundo é sua múltipla capacidade de cativar - e por que não? - apaixonar a humanidade. Como biólogo, admito que ao ler o livro "FOC: Farinha de Ossos Calcinada: Alternativa tecnológica para calagem e fosfatagem em solos tropicais?", em minha singela compressão do universo, fantasiei que seria incapaz de compreender esse outro panorama dos aspectos agrários, em que diversos autores que o compõem apresentavam para a academia. Os autores, sendo agrônomos, engenheiros florestais, químicos, médicos veterinários, zootecnistas, pós-graduandos e estudantes de graduação, conseguiram alcançar o que muitos intergrantes das cátedras científicas brasileiras buscam com muita luta, que é compor a mais suave poesia do conhecimento científico. Em cinco capítulos sobre a Farinha de Ossos Calcinada, desde seus aspectos relativos à pecuária na Amazônia, quanto às bases de sua composição química e sua visão de oportunidade quanto à realidade presente na Amazônia Brasileira, torna-se presente um trabalho que deve estar em diversas bibliotecas e prateleiras para consulta, não só com intuito de solucionar questões sobre seu tema, mas para adicionar o estímulo para pensar e refletir sobre o quão importante é a multidisciplinaridade de um trabalho, como verdadeiro e puro estímulo para todos. Não há dúvidas de que a sabedoria é a mãe da ciência, e deslumbro a primeira como uma prova de sua criação. Para degustação dos leitores, o livro é apresentado de forma concisa e direta, e assim de fácil assimilação, potencializando o trinômio do conhecimento: a evidência, a certeza e a verdade.

Dr. Mahmoud Nagib Mehanna

Cuiabá, 3 de novembro de 2018. 



\section{Sumário}

13

APRESENTAÇÃO

15

1. A PECUÁRIA BRASILEIRA: O CASO DA AMAZÔNIA

Fábio Régis de Souza

Isac Fogaça

Marlos Oliveira Porto

Odair Queiroz Lara

21 2. DEGRADAÇÃO E RECUPERAÇÃO DE PASTOS

Douglas Borges Pichek

Jucilene Cavali

Marlos Oliveira Porto

27 3. A QUEIMA DE OSSOS E A GERAÇÃO DE CALOR Acácio Bezerra de Mira

Adjalma Campos de França Neto

Ariane Evald

Jhonnatan Wilker de Oliveira

33 4. CARACTERÍSTICAS FÍSICAS DA FARINHA DE OSSOS CALCINADA

Efraim Borges da Silva

Thassiane Telles Conde

Rosalvo Stachiw

37

5. CARACTERÍSTICAS QUÍMICAS APÓS A CALCINAÇÃO

Thassiane Telles Conde

Rosalvo Stachiw

43 6. AVALIAÇÃO QUALITATIVA DA FARINHA DE OSSOS CALCINADA

Diego Boni

João Batista Dias Damaceno

Lindomar Alves de Souza

Tiago Gyovani de Melo Baldino 
CALCINADA

Elvino Ferreira

Emanuel Maia

Jairo Rafael Machado Dias

Jerônimo Vieiria Dantas Filho

Jucilene Cavali

Marisa Pereira Matt

Marlos Oliveira Porto

53 8. NECESSIDADES DAS FORRAGEIRAS QUANTO AO CÁLCIO Aderson Cristian Bergamin

57 9. NECESSIDADES DAS FORRAGEIRAS QUANTO AO FÓSFORO

Jairo Rafael Machado Dias

65 10.FARINHA DE OSSOS CALCINADA EM FORRAGEIRAS

Alisson Vinicius Lorencetti Ferreira

Elvino Ferreira

Jucilene Cavali

91 11. POTENCIAL DE EMPREGO DA FARINHA DE OSSOS

CALCINADA ACIDIFICADA NA HORTICULTURA: ESTUDO DE CASO - RÚCULA

Anna Frida Hatsue Modro

Emanuel Maia

Sheyla Ariene Ramos de Campos

103 12. POTENCIALIDADES DO USO DA FARINHA DE OSSOS

Adjalma Campos de França Neto

Elvino Ferreira

Jerônimo Vieiria Dantas Filho

Klaus Casari Saturnino

Thais Rabelo dos Santos

115 SOBRE OS AUTORES 


\section{APRESENTAÇÃO}

Das crianças obtemos parte da sabedoria que vamos perdendo com o caminhar da vida. Por exemplo, "por que as plantas são verdes?" Você, já preocupado com clorofila, pigmentos etc., é arrebatado com a seguinte resposta: "É porque verde não enjoa!" Assim também acontece em: "Como é possível haver uma floresta tão exuberante em solo tão pobre?” É da ciclagem eficiente de seus nutrientes que tudo aquilo é possível. É claro que as consequências desses questionamentos são dirigidas para os sistemas agropecuários de produção. Tanto a agricultura quanto a pecuária devem aprender com as florestas para que a vida humana no planeta não seja comprometida. Essa é uma lição que deveremos aprender propondo e testando tecnologias que têm a proposta de gerar um aproveitamento eficiente dos nutrientes desperdiçados como resíduos da atividade humana. Esse é o objetivo dos integrantes do Grupo de Estudos em Produção Animal e Aproveitamento de Resíduos (GEPAAR), registrado no Diretório do Grupo de Pesquisa do Brasil do Conselho Nacional de Desenvolvimento Científico e Tecnológico (CNPq), desde 30 de junho de 2010 (http://www. unir.br/menus/pesquisa/gpesquisa.pdf). As ações desse grupo objetivam responder certos questionamentos da sociedade e gerar oportunidade para que os discentes diretamente envolvidos possam desenvolver seus trabalhos de conclusão de curso (TCC). É importante ressaltar que esse tipo de iniciativa reduz custos, viabilizando a execução de projetos além de contribuir com a formação de recursos humanos. Cria a oportunidade de colaboração entre os participantes e atende de forma científica questionamentos "vindos da extensão". Este livro é o resultado dos esforços relativos a uma melhor compreensão do tema (Farinha de Ossos) e dos trabalhos desenvolvidos para esse fim. Na oportunidade, registramos nossos agradecimentos a todos que colaboram para tal feito.

Este livro trata de aspectos básicos e aplicados relacionados a farinha de ossos calcinada, no intuito de concentrar informações a respeito do assunto, como forma de disponibilizá-las aos estudantes dos cursos de 
ciências agrárias ou a qualquer pessoa interessada. O livro está organizado em capítulos, a fim de abordar, de forma focal, algumas variantes do assunto. O leitor irá notar que seu desenvolvimento inicial aborda as questões das pastagens na Amazônia, de modo a ser apresentado como ocorreu sua formação, dos erros de uso que acarretam sua degradação e de como pode se dar o aproveitamento desse resíduo, iniciando-se, como exemplo, a geração de calor. Assim, se remete à necessidade de compreender a caracterização dessa substância, sendo portanto abordado seu aspecto Físico-químico e as características dos ossos após o processo de calcinação. Apresentadas algumas reações químicas de interesse agropecuário, passa a ser abordada a avaliação qualitativa, já que, no ponto de vista dos agroecossistemas, é de interesse o conhecimento dos níveis de Cálcio e Fósforo nesse material, bem como seu comportamento em termos de solubilidade. No sentido de ser criada uma base de entendimento prático ou aplicado, os autores tiveram a preocupação de abordar as necessidades de Cálcio e Fósforo para as plantas forrageiras. Seguindo a isso, são oferecidos alguns dados gerados como trabalhos de conclusão de curso (TCC) abordando plantas forrageiras e um estudo com rúcula, em que se usou farinha de ossos calcinada e acidificada, de forma a ser alterada sua solubilidade natural. Finalmente, o livro encerra discutindo outras possibilidades e potencialidades da farinha de ossos calcinada, de forma a apresentar possibilidades para o desenvolvimento científico e tecnológico com o uso desse material. Em toda obra, são apresentados figuras, quadros e gráficos, no intuito de tornar claras as informações discutidas. Com isso, esperamos que ela seja de alguma ajuda às pessoas interessadas e com isso contribuir com o acesso a esse tipo de informação. 


\section{A PECUÁRIA BRASILEIRA: O CASO DA AMAZÔNIA}

Fábio Régis de Souza

Isac Fogaça

Marlos Oliveira Porto

Odair Queiroz Lara

$\mathrm{Na}$ Amazônia, dos quase 5 milhões de $\mathrm{km}^{2}$ de florestas, mais de 587 mil km² já foram desmatados, tendo-se como referência o território brasileiro (BRASIL, 2002 apud KRUSCHE et al., 2005), principalmente devido ao rápido desenvolvimento ocorrido a partir da década de 70 (KRUSCHE et al., 2005). A principal forma de ocupação consistiu na derrubada e queima da floresta, o que também foi observado em Rondônia, onde a ocupação se deu através de uma pecuária bovina extensiva como principal atividade econômica do Estado (MARCONATO, 2002). Entre 1970 e 1990, o estado de Rondônia teve um impulso no desenvolvimento e ocupação, aumentando a população de 111.064 pessoas residentes em 1970 para 1.379 .787 pessoas em 2000 (IBGE, 2003), desenvolvendo intensamente a atividade pecuária bovina nessa região, associada à perda de $24,4 \%$ de sua cobertura florestal nativa (BRASIL, 2002).

A ocupação 'desorganizada' e a exploração extensiva de bovinos, por meio da substituição da vegetação nativa pelas pastagens, ocorreram com a retirada da madeira de alto valor comercial, queimando-se o restante para facilitar a mecanização dos solos e permitir a introdução de espécies de gramíneas forrageiras. $O$ potencial produtivo inicial das pastagens era alto, devido à grande disponibilização momentânea de nutrientes no solo, pela queima da vegetação (BRAZ et al., 2004). As altas produtividades das forrageiras também foram verificadas com os animais nos primeiros anos de exploração do pasto (COSTA et al.,2008). A sazonalidade, proporcionando maior produtividade das gramíneas no período das chuvas em relação ao período seco, dificultando o dimensionamento do rebanho, tornou inevitável o superpastejo no período menos favorável ao crescimento 
das forrageiras (BRAZ et al., 2004). Esses fatos, associados à ocorrência de plantas invasoras (SERÃO \& HOMMA, 1991; DIAS-FILHO, 2003; BRAZ et al., 2004), à compactação do solo, à acidez, aos níveis de alumínio tóxico e à deficiência de fósforo do solo, seguidos por práticas de recuperação baseadas em fogo e mecanização (com ou sem o emprego de calcário e fosfatos), desencadeiam o processo de degradação dos pastos (FERREIRA, 1995; BODDEY et al., 2004; BRAZ et al., 2004).

A degradação das pastagens pode ser caracterizada como um processo evolutivo de perda de vigor e produtividade da forrageira, sem a possibilidade de recuperação natural, o que afeta o desempenho dos animais e compromete os recursos naturais, em seu estágio mais avançado (SPAIN \& GUALDRON, 1991; MEIRELES, 1993; MACEDO, 2002). Para a Amazônia Legal (e Rondônia inclusive), estima-se que 20 milhões de hectares estão em diferentes estágios de degradação (KITAMURA, 1994; OLIVEIRA et al., 2001).

Nesse processo evolutivo, a queda de produção, com o passar do tempo, vai se agravando, à medida que se verificam a ausência de correção e adubação e a adoção de práticas como as da queimada para a limpeza dos pastos como método mais utilizado pela maioria dos pecuaristas (FERNANDES \& GUIMARÃES, 2002). Acrescido a isso, a ausência de práticas conservacionistas de manejo do solo, o uso de germoplasmas impróprios, a má formação inicial das pastagens, as altas pressões de pastejo e a ocorrência de pragas e doenças tendem a agravar o problema (FERNANDES \& GUIMARÃES, 2002; MACEDO, 2002). A perda do potencial produtivo da forrageira faz com que os pecuaristas derrubem novas áreas para a formação de pastagem. É importante ressaltar que, além de o solo ficar comprometido com a alteração em sua estrutura, redução das taxas de infiltração e da capacidade de retenção de água, observam-se ainda o assoreamento dos mananciais de água e a perda da biodiversidade (MACEDO, 2002).

Nesse contexto, o aumento das necessidades humanas por alimentos levou ao cenário internacional a surpreendente reportagem de que a "Coréia do Norte irá suspender seu programa de enriquecimento de Urânio em troca de toneladas de alimentos dos Estados Unidos" (O GLOBO, 2012). 
No Brasil, verifica-se a expansão de áreas de cultivos agrícolas para a produção de grãos e por gramíneas, para a formação de pastos em detrimento de ambientes naturais.

$\mathrm{Na}$ Amazônia, a ocupação da floresta por pastagens cultivadas constitui importante problema ambiental (DIAS-FILHO, 2003). O manejo incorreto dos pastos leva à degradação do solo e à infestação por plantas daninhas (SERRÃO \& ROMA, 1991, DIAS-FILHO, 2003), comprometendo a recuperação natural, acarretando na redução do rendimento e do desempenho animal e, mesmo, a perda da biodiversidade (MACEDO, 2002). O emprego do modelo de desmatamento com o uso do fogo tem foco nas preocupações mundiais quanto às questões relativas às mudanças climáticas pela emissão de gás carbônico e o consequente agravamento do efeito estufa (CERRI et al, 2009; MACHADO, 2009), o que torna prioritário o desenvolvimento de tecnologias para a sustentabilidade e a preservação ambiental.

\section{Referências}

BRASIL. INPE. Monitoring of the Brazilian Amazon forest by satellite 1999-2000. National Institute for Space Research. 2002. São José dos Campos, SP, Brazil.

BRAZ, S. P.; URQUIAGA, S.; ALVES, B. J. R.; BODDEY, R. M. Degradação do solo e a recuperação do potencial produtivo em sistemas de baixo "input" tecnológico na Região do Cerrado. Circular Técnica, 9. Embrapa, Seropédica, 2004, 1-8.

BODDEY, R. M.; MACEDO, R.; TARRÉ, R. M.; FERREIRA, E.; OLIVEIRA, O. C. de; REZENDE, C. D. P.; CANTARUTTI, R. B.; PEREIRA, J. M.; ALVES, B. J. R.; URQUIAGA, S. Nitrogen cycling in Brachiaria pastures: the key to understanding the process of pasture decline. Agriculture Ecosystems \& Environment, Amsterdam, v. 103, p. 389403, 2004.

CERRI, C. C.; MAIA, S. M. F.; GALDOS, M. V.; CERRI, C. E. P.; FEILG, B. J.; BERNOUX, M. Brazilian greenhouse gas emissions: the importance of agriculture and livestock. Scientia Agricola (Piracicaba, Braz.), Piracicaba, v. 66, n. 6, p. 831-843, Dec. 2009.

COSTA, N. L.; TOWNSED, C. R.; MAGALHÃES, J. A.; PEREIRA, R. G. A. Nitrogênio e Fósforo na recuperação de pastagens de Brachiaria brizantha cv. Marandú. PUBVET, v.2, n. 24 , p. $5-11,2008$.

DIAS-FILHO, M. B. Degradação de pastagens: processos, causas e estratégias de recuperação. Belém. PA, Embrapa Amazônia Oriental, 2003. 152 p. 
FERNANDES, L. C.; GUIMARÃES, S. C. P. Atlas geoambiental de Rondônia. Porto Velho, 2002. 138 p.

FERREIRA, E. A excreção de bovinos e as perdas de nitrogênio nas pastagens tropicais. 1995. 143 f. Dissertação (Mestrado) - Universidade Federal Rural do Rio de Janeiro, Seropédica, RJ, 1995.

INSTITUTO BRASILEIRO DE GEOGRAFIA E ESTATÍSTICA. SIDRA - Banco de dados agregados, 2008. Disponível em http://www.sidra.ibge.gov.br Acesso em maio de 2009 .

INSTITUTO BRASILEIRO DE GEOGRAFIA E ESTATÍSTICA. Diretoria de pesquisas. Área do Estado 2009. Disponível em: http://www.ibge.gov.br/estado sat/perfil. php? sigla=ro. Acesso em: 6 jun. 2010.

KITAMURA, P. C. Amazônia e o desenvolvimento sustentável. Brasília. Embrapa, 1994. $182 \mathrm{p}$.

KRUSCHE, A. V.; BALLESTER, M. V. R.; VICTORIA, R. L.; BERNARDES, M. C.; LEITE, N. K.; HANADA, L.; VICTORIA, D. C.; TOLEDO, A. M.; OMETTO, J. P.; MOREIRA, M.Z.; GOMES, B. M.; BOLSON, M. A.; GOUVEIA NETO, S.; BONELLI, N.; DEEGAN, L.; NEILL, C.; THOMAS, S.; AUFDENKAMPE, A. K.;RICHEY, J. E. Efeitos das mudanças do uso da terra na biogeoquímica dos corpos d'água da bacia do rio Ji-Paraná, Rondônia. Acta Amazonica, Manaus, v. 35, n. 2, p. 197-205, 2005.

MACEDO, M. C. M.; KICHEL, A. N.; ZIMMER, A. H. Degradação e alternativas de recuperação e renovação de pastagens. Embrapa Gado de Corte. Comunicado Técnico no 62, Campo Grande, MS, p. 4, 2000.

MACHADO, L. de O. R. Desflorestamento na amazônia brasileira: ação coletiva, governança e governabilidade em área de fronteira. Sociedade e Estado, Brasília , v. 24, n. 1, p. 115-147, Abr. 2009.

MARCONATO, R. Análise da ocupação econômica do estado de Rondônia nos anos 90 segundo o modelo de Krugman. 2002. FE/ESALQ/USP, CENA/USP. Monografia. 108p. il.

MEIRELLES, N. M. F. Degradação de pastagens: critérios de avaliação. In: ENCONTRO SOBRE RECUPERAÇÃO DE PASTAGENS, 1. Nova Odessa, 1993. Anais... Nova Odessa, Instituto de Zootecnia, 1993, p. 27-43.

O GLOBO. Por comida, Coréia do Norte anuncia suspensão do programa nuclear. Edição do dia $1^{\circ}$ de março de 2012. Disponível em: http://g1.globo.com/bom-dia-brasil/noticia/2012/03/por-comida-coreia-do-norte-anuncia-suspensao-do-programa-nuclear.html. Acesso em 3 de março de 2014.

OLIVEIRA, O. C.; OLIVIERA, I. P.; FERREIRA, E. Response of degraded pastures in the Brazilian Cerrado to chemical fertilization. Pasturas Tropicales, v. 13, p. 14-18, 2001. 
SERRÃO, E.A.S.; HOMMA, A.K.O. Agriculture in the Amazon: the question of sustainability. Washington: Committee for Agriculture Sustainability and Environment in the Humid Tropics, $1991.100 \mathrm{p}$.

SPAIN, J. M.; GUALDRON, R. Degradación e rehabilitación de pasturas. In: LASCANO, C.; SPAIN, J.M. (Eds.). Estabelecimiento y renovación de pasturas. Cali; CIAT, 1991. $426 \mathrm{p}$. 



\title{
2. DEGRADAÇÃO E RECUPERAÇÃO DE PASTOS
}

\author{
Douglas Borges Pichek \\ Jucilene Cavali \\ Marlos Oliveira Porto
}

Na região Amazônica, a substituição da floresta primária para ocupação da agricultura e pecuária em solos altamente intemperizados dos trópicos resultou em rápida perda de matéria orgânica, problemas como erosão, perda de nutrientes e a compactação (PICOLLO et al., 2008), constituindo uma das alterações mais importantes e problemáticas desse ecossistema (FERNANDO \& GUIMARÃES, 2002; DIAS-FILHO, 2003), o que, associado ao manejo inadequado das pastagens, compromete não só o desempenho animal como também os recursos naturais.

Ambientes degradados são ambientes complexos. Alguns fatores são prévios e outros se estabelecem com os erros de manejo das pastagens. Por exemplo, tem-se que a deficiência de fósforo é ampla e de maior importância econômica, envolvendo bovinos em condições de pastagens (TOKARNIA et al., 1988). No cerrado, mesmo no período das águas, as concentrações de fósforo nas forrageiras não são suficientes para suprir as necessidades das diferentes categorias animais e manter bom nível de produção (ROSA 1994). Nessa situação, a adubação fosfatada é considerada de vital importância, principalmente na fase de estabelecimento das pastagens (DIAS-FILHO, 2006). Contudo, a presença de óxidos de ferro e alumínio, entre outros, promove a forte adsorção de fosfato, reduzindo sua disponibilidade quando se aplica adubação fosfatada (ALMEIDA NETO, 1992). $\mathrm{Na}$ forrageira, o desbalanço nutricional reflete negativamente na produtividade da planta, uma vez que o fósforo está envolvido na transferência de energia da célula, compõe ácidos nucléicos, na respiração e na fotossíntese (GRANT; FLATEN, 2001; RAVEN; EVERT; EICHHORN, 2001).

Uma das formas de se elevar a disponibilidade de fósforo está na correção dos baixos níveis de acidez do solo com a aplicação de calcário. 
Além de elevar o $\mathrm{pH}$ e a disponibilidade de fosfato, há o fornecimento de cálcio e magnésio, a redução dos efeitos tóxicos do alumínio, do manganês, entre outros (SIQUEIRA, 1986; WERNER, 1994). Na planta, o cálcio compõe a parede celular, é cofator de enzimas, está envolvido na permeabilidade da membrana, entre outras funções (RAVEN; EVERT; EICHHORN, 2001).

Como fatores estabelecidos com os erros de manejo, são relatados que, tanto o superpastejo quanto o cultivo intensivo do solo com o uso da aração e gradagens podem comprometer características de solo como porosidade total, aeração, armazenamento de disponibilidade de água para as plantas e resistência mecânica à penetração de raízes (KLEIN, 1998). Por exemplo, relata-se a maior resistência à penetração (Penetrographer ${ }^{\circledR}$ SC-60) em área degradada $(5,92 ; 4,96 ; 4,61$ e 6,92 Mpa) em relação à cultivada com adubos verdes e pasto $(2,72 ; 3,70 ; 5,04$ e $6,24 \mathrm{Mpa})$ em diferentes profundidades $(0-0,05 ; 0,05-0,10 ; 0,-10 ; 0,20$ e 0,20-0,40 m; respectivamente) (CAMPOS; ALVES, 2006). Com elevada resistência à penetração, há o comprometimento do sistema radicular, e conseqüentemente ausência de plantas, de cobertura morta, menor conteúdo de água transferência de calor e aeração no perfil (SILVA et al. 2003).

Considerando densidade de solo, valores de 1,70 ou $1,80 \mathrm{~g} \mathrm{~cm}^{-3}$ já geram dificuldades de penetração de raízes, sendo que $1,90 \mathrm{~g} \mathrm{~cm}^{-3}$ já inibem seu crescimento e sua presença no perfil (KIEHL, 1979; CAMARGO; ALLEONI, 1997; LIMA, 2007). Considerando as relações intrínsecas entre as características, tem-se que a taxa de infiltração de água é a mais sensível para detecção de alterações nos solos. Comparativamente, pode ser citado que em solos sob florestas se observam taxa de infiltração de $314 \mathrm{~mm}$ $\mathrm{h}^{-1}$, enquanto, para a mesma classe de solo, mas cultivado de forma convencional, essa taxa não ultrapassou $63 \mathrm{~mm} \mathrm{~h}^{-1}$, potencializando o escorrimento superficial, causando erosão (FIORIN, 2008).

Para a recuperação das pastagens práticas, a aração e a gradagem podem ser utilizadas. Seu emprego inadequado reduz, contudo, a matéria orgânica do solo, aumentando os riscos de erosão, além de poder gerar dependência quanto a insumos industrializados e produtos fitossanitários 
(LIMA, 2007). A integração de métodos químicos, físicos e a integração de culturas geram, no entanto, resultados satisfatórios. Respostas de superioridade produtiva em Brachiaria brizantha são demonstradas quando da aplicação de gradagem + NPK + micronutrientes $\left(30.025 \mathrm{~kg} \mathrm{ha}^{-1}\right)$ ou plantio direto de arroz $+\mathrm{NPK}+$ micronutrientes $\left(28.267 \mathrm{~kg} \mathrm{ha}^{-1}\right)$ ou plantio direto de soja + PK + micronutrientes $\left(27.735 \mathrm{~kg} \mathrm{ha}^{-1}\right)$, em comparação à aplicação de herbicidas + NK + micronutrientes $\left(17.057 \mathrm{~kg} \mathrm{ha}^{-1}\right)$, gerando resultados próximos aos do tratamento testemunha $\left(17.040 \mathrm{~kg} \mathrm{ha}^{-1}\right)$. Esse experimento se desenvolveu em Rondônia em área degradada, brangendo as épocas das águas e seca. Os autores comentam que a adubação fosfatada foi efetiva no incremento de produção da matéria seca de Brachiaria brizantha (NORONHA et al. 2010).

Para o Agreste de Pernambuco, em área degradada de um Regossolo com fertilidade originalmente baixa, a associação de deferimento + plantio direto de milho promoveu resultados melhores quando comparados aos tratamentos de diferimento + gradagem e diferimento + gradagem + milho, para a produção de matéria seca em Brachiaria decumbens Stapf. Relatam os autores que ocorreu interação entre as adubações estudadas (0 e $100 \mathrm{~kg} \mathrm{ha} \mathrm{ha}^{-1}$ de $\mathrm{N}$ e $0100 \mathrm{~kg} \mathrm{ha}^{-1}$ de $\mathrm{P}_{2} \mathrm{O}_{5}$ ) (YDOYAGA et al. 2006).

Com os exemplos citados, procura-se demonstrar a importância do emprego correto das técnicas de recuperação de áreas degradadas. Ainda pode ser considerado que a otimização para o uso de adubos está no emprego de sistemas de integração lavoura pecuária (ILP) ou mesmo em sistemas agroflorestais ( $\mathrm{SAF}$ ), no sentido de capitalizar o produtor e gerar condições iniciais positivas para o estabelecimento de cultivos (NORONHA et al. 2010).

\section{Referências}

CAMARGO, O. A.; ALLEONI, L. R. F. Compactação do solo e desenvolvimento das plantas. Piracicaba, Escola Superior de Agricultura Luiz de Queiroz, 1997, 123 p.

CAMPOS, F. S. de; ALVES, M. C. Resistência à penetração de um solo em recuperação sob sistemas agrosilvopastoris. Revista Brasileira de Engenharia Agrícola e Ambiental, Campina Grande, v. 10, n. 3, p. 759-764, set. 2006. 
DIAS-FILHO, M. B. Degradação de pastagens: processos, causas e estratégias de recuperação. Belém - PA, Embrapa Amazônia Oriental, 2003.152 p.

DIAS-FILHO, M. B. Degradação e recuperação de pastagens. In: PEDREIRA, C.G.S.; MOURA, J. C. de; DA SILVA, S.C; FARIA, V. P. de (Eds.). As pastagens e o meio ambiente. Piracicaba: FEALQ 2006, p.185-220.

FERNANDES, L. C.; GUIMARÃES, S. C. P. Atlas geoambiental de Rondônia. Porto Velho, 2002. 138 p.

FIORIN, T. T. Estimativa da infiltração de água no solo a partir de pedofunções. 2008. Tese (Doutorado) - Programa de Pós-graduação em Ciência do Solo. UFSM, Santa Maria. 2008. 116 p.

GRANT, C.A; FLATEN, D.N. Importância do fósforo no desenvolvimento inicial da planta. Piracicaba: Potafós, 2001. p.1-5. (Informações Agronômicas, 95)

KIEHL, E. J. Manual de Edafologia: relações solo-planta. Piracicaba, Agronômica Ceres, 1979. $264 \mathrm{p}$.

KLEIN, V. A. Propriedades físico-hídrico-mecânicas de um Latossolo Roxo, sob diferentes sistemas de uso e manejo. 1998. 150 f. Tese (Doutorado) - Escola Superior de Agricultura Luiz de Queiroz, Piracicaba, 1998.

LIMA, D. Indicadores de qualidade do solo sob sistema de produção agrícola convencional em conversão para agronegócio. 2006/7. Dissertação de Mestrado - UEL, Londrina, 2007.63 p.

NORONHA, N. C.; ANDRADE, C. A.; LIMONGE, F. C.; CERRI, C. C.; CERRI, C. E. P.; PICCOLO, M. C.; FEIGL, B. J. Recovery of degraded pasture in Rondônia: macronutrients and productivity of Brachiaria brizantha. Revista Brasileira de Ciência do Solo, Viçosa, v. 34, n. 5, p. 1711-1720, out. 2010.

PICOLLO, G. A.; ANDRIULO, A. E.; MARY, B. Changes in soil organic matter under different land management in Misiones province (Argentina). Scientia Agricola (Piracicaba, Braz.), v. 65, n. 3, p. 290-297, Piracicaba, 2008.

RAVEN, P. H.; EVERT, R. F.; EICHHORN, S. E. Biologia Vegetal. 7ª ed. Rio de Janeiro: Guanabara Koogan, 2007. 830 p.

ROSA, I. V. Suplementação mineral de bovinos sob pastejo. In: SIMPÓSIO BRASILEIRO DE FORRAGEIRAS E PASTAGENS, 1994, Campinas. Anais... [S.1.]: Colégio Brasileiro de Nutrição Animal, [1994]. p. 213-243.

SIQUEIRA, C. Calagem para plantas forrageiras. In: MATTOS et al. (eds.). Calagem e adubação de pastagens. Piracicaba: Associação Brasileira para Pesquisa da Potassa e do Fosfato, 1986. 476p.: Il. 
SILVA, R. B.; JÚNIOR, M. S.; SILVA, F. A. M.; FOLE, S. M. O tráfego de máquinas agrícolas e as propriedades físicas, hídricas e mecânicas de um Latossolo dos Cerrados. Revista Brasileira de Ciência do Solo, v. 27, n. 6, p. 973-983, 2003.

TOKARNIA, C. H.; DÖBEREINER, J. \& MORAES, S. S. Situação atual e perspectiva da investigação sobre nutrição mineral em bovinos de corte no Brasil. Pesquisa Veterinária Brasileira, Rio de Janeiro, v.8, n.1-2, p. 1-16, jan./ jun. 1988.

WERNER, J. C. Calagem para plantas forrageiras. In: PEIXOTO et al. Pastagens: Fundamentos da exploração tracional. 2a ed. Piracicaba: FEALQ 1994. p. 111-119; (FEALQ: Série atualização em zootecnia, 10). 908p. ;Il.

YDOYAGA, D. F.; LIRA, M. A.; SANTOS, M. V. F.; DUBEUX JÚNIOR, J. C. B.; SILVA, M. C.; SANTOS, V. F.; FERNANDES, A. P. M. Métodos de recuperação de pastagens de Brachiaria decumbens Stapf. no Agreste Pernambucano. Revista Brasileira de Zootecnia, Viçosa, v. 35, n. 3, p. 699-705, jun. 2006. 



\title{
3. A QUEIMA DE OSSOS E A GERAÇÃO DE CALOR
}

\author{
Acácio Bezerra de Mira \\ Adjalma Campos de França Neto \\ Ariane Evald \\ Jhonnatan Wilker de Oliveira
}

Em termo de aproveitamento de resíduos, deve-se ter atenção na importante quantidade de ossos oriundos de abates em frigoríficos. Considerando que o abate de bovinos no $2^{\circ}$ semestre de 2013 foi de 8,5 milhões de cabeças (LISBOA, 2013), e que seu peso médio pode ser representado por $250 \mathrm{~kg}$ (HESS, 2003; NOGUEIRA, 2014), tem-se que 16\% desse peso se referem aos ossos (PASCOAL, 2009; CLIMACO et al., 2006), o que representa a produção de 340 milhões de $\mathrm{kg}$ de ossos gerados com a atividade frigorífica de bovinos.

De forma geral, os resíduos orgânicos não são de fácil processamento, mas o seu não aproveitamento representa um desperdício energético e desconsidera os processos de ciclagem de nutrientes. Cidades com açougues, abatedouros ou frigoríficos de pequeno porte, que não possuem infraestrutura para graxaria, há o descarte de resíduos, sem qualquer controle, em lixões. O descarte de resíduos de forma incorreta agrava problemas ambientais, sanitários e econômicos (MACHADO, 1998; YAMAMOTO et al., 2007; MATTAR; FRADE JÚNIRO; OLIVEIRA, 2013).

Muitos materiais podem ser usados para a geração de energia térmica. $\mathrm{Na}$ indústria, diversos produtos combustíveis são usados para tal finalidade. Para a agricultura familiar ou lugares com pequenos comércios, geralmente a lenha é utilizada. Geralmente, seu preço inferior ao dos demais combustíveis a torna a principal fonte de energia para alguns setores. Se, por um lado, a lenha proporciona ao produto final valor mais competitivo, por outro lado o desmatamento sistemático já se constitui em ameaça aos recursos naturais, além de provocar a desertificação para ecossistemas cujas condições 
edafoclimáticas são caracterizadas por baixa intensidade de chuvas, concentradas em poucos meses do ano e solos rasos (CARNEIRO et al., 2013).

Para a madeira, a obtenção de energia com o fornecimento de altas temperaturas promove a decomposição térmica dos seus componentes químicos, passando por um processo de carbonização. Cada um desses componentes apresenta decomposição mais pronunciada em faixas de temperaturas distintas. Por exemplo, as hemiceluloses sofrem maiores picos de degradação entre 200 e $300{ }^{\circ} \mathrm{C}$, já celulose entre 240 e $350{ }^{\circ} \mathrm{C}$, enquanto a lignina, entre 350 e $500{ }^{\circ} \mathrm{C}$. Devido à complexidade do processo de conversão da madeira em energia, faz-se necessário avaliar o perfil de sua decomposição térmica, principalmente considerando que a madeira é material heterogêneo por apresentar, entre outras características, diferenças significativas em suas propriedades (CARNEIRO et al. 2013). Já os ossos apresentam grande homogeneidade, apesar de sua origem natural, e as partículas se arranjam em estruturas equiaxiais (GOUVÊA et al. 2008). A presença de gordura nesse material facilita o processo de queima e, com isso, a economia de lenha (MATTAR; FRADE JÚNIOR; OLIVEIRA, 2013).

Para avaliação calorimétrica dos materiais, pode-se destacar a análise termogravimétrica (TGA), que acompanha a variação da propriedade física da massa da amostra em função do tempo (com a temperatura constante) ou da temperatura (CAVALHEIRO, 1995), permitindo acompanhar possíveis processos de degradação do material na temperatura estudada, sendo uma ferramenta importante quando se deseja selecionar espécies para fins energéticos (OLIVEIRA, 2009). Já com uso da técnica da calorimetria diferencial exploratória (DSC), pode-se determinar a temperatura de fusão e de decomposição, além de fornecer dados sobre a estabilidade térmica de compostos (SILVA et al. 2004).

Para ossos, o comportamento térmico se inicia a partir de $100{ }^{\circ} \mathrm{C}$, com a diminuição da quantidade de massa do material devido à perda de água na forma de vapor. A evaporação da água é uma reação endotérmica. Em aproximadamente $300{ }^{\circ} \mathrm{C}$, inicia-se uma segunda reação exotérmica que se prolonga até aproximadamente $700{ }^{\circ} \mathrm{C}$, quando é 
observada uma queda acentuada da massa, que deve estar provavelmente relacionada à reação de combustão da matéria orgânica contida nos ossos bovinos. Quando o material é calcinado a $450{ }^{\circ} \mathrm{C}$, temperatura em que a matéria orgânica é pirolisada, ocorre a formação de uma camada de carvão nos ossos que é eliminada a temperaturas superiores (MIYAHARA; GOUVEA; TOFFOLI, 2007). O rendimento médio desse processo é estimado em 24,44 \% (MATTAR; FRADE JÚNIOR; OLIVEIRA, 2013), podendo variar entre 10 a 31\% de cinzas produzidas (COUTAND et al. 2008). Destaque-se que, tanto para pequenas quanto para grandes quantidades produzidas, deve-se ter em mente o melhor destino para sua utilização.

$\mathrm{Na}$ Tabela 1, são apresentados alguns materiais comburentes, sua densidade e seu poder calorífico superior.

Tabela 1 - Poder calorífico e densidade de alguns materiais usados como combustíveis.

\begin{tabular}{lcc}
\hline Material & Densidade $\left.\mathbf{( g ~ c m}{ }^{-3}\right)$ & Poder calorífico superior* \\
\hline Gasolina & 0,742 & $8325 \mathrm{kcal} \mathrm{L}^{-1}$ \\
\hline Diesel & 0,852 & $9160 \mathrm{kcal} \mathrm{L}^{-1}$ \\
\hline Álcool Hidratado & 0,809 & $5380 \mathrm{kcal} \mathrm{L}^{-1}$ \\
\hline QAV & 0,788 & $11000 \mathrm{kcal} \mathrm{kg}^{-1}$ \\
\hline GLP & 0,556 & $11750 \mathrm{kcal} \mathrm{kg}^{-1}$ \\
\hline Óleo Combustível 1A & 1,000 & $10130 \mathrm{kcal} \mathrm{kg}^{-1}$ \\
\hline Nafta & 0,691 & $11360 \mathrm{kcal} \mathrm{kg}^{-1}$ \\
\hline Gás Natural & - & $9400 \mathrm{kcal} \mathrm{m}^{-3}$ \\
\hline Coque Verde & 1,040 & $8500 \mathrm{kcal} \mathrm{kg}^{-1}$ \\
\hline Carvão Mineral & - & $6000 \mathrm{kcal} \mathrm{kg}^{-1}$ \\
\hline Carvão Vegetal & - & $1680 \mathrm{kcal} \mathrm{dm}^{-3}$ \\
\hline Lenha & - & $990 \mathrm{kcal} \mathrm{dm}^{-3}$ \\
\hline Farinha de Carne e ossos & - & $4036 \mathrm{kcal} \mathrm{kg}^{-1}$ \\
\hline Mimosa tenuiflora & 0,90 & $4823 \mathrm{kcal} \mathrm{kg}^{-1}$ \\
\hline Aspidosperma pyrifolium & 0,62 & $4720 \mathrm{kcal} \mathrm{kg}^{-1}$ \\
\hline Croton sondedrianus & 0,66 & $4646 \mathrm{kcal} \mathrm{kg}^{-1}$ \\
\hline Caesalplinia pyramidalis & 0,79 & $4442 \mathrm{kcal} \mathrm{kg}^{-1}$ \\
\hline
\end{tabular}




\begin{tabular}{lcc}
\hline Material & Densidade $\left(\mathbf{g ~ c m}^{-3}\right)$ & Poder calorifico superior* \\
\hline Baubinia cheilantha & 0,97 & $4616 \mathrm{kcal} \mathrm{kg}^{-1}$ \\
\hline Commiphora leptophloeos & 0,29 & $4479 \mathrm{kcal} \mathrm{kg}^{-1}$ \\
\hline Piptadenia stipulacea & 0,76 & $4557 \mathrm{kcal} \mathrm{kg}^{-1}$ \\
\hline Combretum leprosum & 0,68 & $4602 \mathrm{kcal} \mathrm{kg}^{-1}$ \\
\hline
\end{tabular}

*Poder calorífico: capacidade potencial de um material desprender determinada quantidade de calor, quanto submetido a queima. O poder calorífico superior é a soma da energia liberada como calor e da energia gasta na vaporização da água presente ou formada na massa da amostra. Já no poder calorífico inferior, desconta-se a energia de condensação da água que estava contida na amostra.

Fonte: CONESA et al. (2005); CARNEIRO et al. (2013); PETROBRÁS (2014).

Em pequenas localidades, a integração para fins coletivos com outros segmentos pode representar o aproveitamento desse recurso energético que varia entre 13 a $30 \mathrm{MJ} \mathrm{kg}^{-1}$, que geralmente é desperdiçado com o descarte dos ossos de pequenos frigoríficos e açougues. Na França, por exemplo, foram incineradas 400.000 toneladas de farinha de carne e ossos, no ano de 2003, como alternativa de combustível para mais de 20 fábricas de cimento (COUTAND et al. 2008).

\section{Referências}

AYLLON, M.; AZNAR, M.; SÁNCHES, J. L.; GEA, G.; ARAUJO, J. Influence of temperature and heating rate on the fixed bed pyrolysis of meat and bone meal. Chemical Engineering Journal, v. 121, n. 1-2, p. 85-96, 2006.

CARNEIRO, A. C. O.; SANTOS, R. C.; CASTRO, R. V. O.; CASTRO, A. F. N. M.; PIMENTA, A. S.; PINTO, E. M.; ALVES, I. C. N. Estudo da decomposição térmica da madeira de oito espécies da região do Seridó, Rio Grande do Norte. Revista Árvore, Viçosa, v. 37, n. 6, p. 1153-1163, dez. 2013.

CAVALHEIRO, E. T. G.; IONASHIRO, M.; BREVIGLIERI, S. T.; MARINO, G.; CHIERICE, G. O. A influência de fatores experimentais nos resultados de análises termogravimétricas. Química Nova, v.18, n.3, p.305-308, 1995.

CLIMACO, S. M.; RIBEIRO, E. L. A.; ROCHA, M. A.; MIZUBUTI, I. Y.; SILVA, L. D. F.; NORO, L.Y.; TURINI, T. Características de carcaça e qualidade de carne de bovinos inteiros ou castrados da raça Nelore, suplementados ou não durante o primeiro inverno. Ciência Rural, Santa Maria, v. 36, n. 6, p. 1867-1872, dez. 2006.

CONESA, J. A.; FULLANA, A.; FONT, R. Dioxin production during the termal treatment of meat and bone meal residues. Chemosphere, v. 59, p. 85-90. 2005. 
COUTAND, M.; CYR, M.; DEYDIER, E.; GUILET, R.; CLASTER, P. Characteristics of industrial and laboratory meat and bone meal ashes and their potential applications. Journal of Hazardous Materials, v. 150, p. 522-532, 2008.

GOUVEA, D.; BERNARD, S.; ALATRISTA, G. A. V.; TOFOLLI, S. M. Efeito da temperatura de calcinação nas propriedades de ossos bovinos para a fabricação de porcelana de ossos. Cerâmica, São Paulo, v. 54, n. 329, p. 423-428, mar. 2008.

HESS, M. Procedência, peso médio de carcaças quentes e rendimento médio de cortes dos bovinos abatidos no matadouro frigorífico Friboi Ltda. Andradina - SP no ano de 2002 e destino das carnes exportadas. 2003. Dissertação (Mestrado em Higiene Veterinária e Processamento Tecnológico de Produtos de Origem Animal) - Universidade Federal Fluminense. 2003. 108p. Niterói, RJ. Disponível em: http://www.uff.br/higiene_veterinaria/ teses/matias_hees_completa_mestrado.pdf Acesso em 30 de janeiro de 2014.

LISBOA, V. Abate de bovinos quebra recorde no segundo trimestre. Agência BrasilEconomia. Disponível em: http://memoria.ebc.com.br/agenciabrasil/noticia/2013-09-19/ abate-de-bovinos-quebra-recorde-no-segundo-trimestre. Acesso em $1^{\mathrm{o}}$ de fevereiro de 2014.

MACHADO, T. M. Silagem biológica de pescado. In: CARVALHO FILHO, J. (Ed.) Panorama da aqüicultura. Rio de Janeiro: 1998. p.30-32.

MATTAR, E. P. L.; FRADE JÚNIOR, E. F.; OLIVEIRA, E. (Eds.) Cinza de ossos fósforo e cálcio para a agricultura.. Cruzeiro do Sul, AC: UFAC, 2013. 25 p.

MIYAHARA, R. Y.; GOUVEA, D.; TOFFOLI, S. M. Obtenção e caracterização de cinza de ossos bovinos visando à fabricação de porcelana de ossos - bone china. Cerâmica, São Paulo, v. 53, n. 327, p. 234-239, set. 2007.

NOGUEIRA, M. P. Sua propriedade: Peso ao abate, resultados e relação de troca. Bigma Consultoria. Disponível em: http://www.diadecampo.com.br/zpublisher/materias/Materia. asp?id=22689\&secao=Sua\%20Propriedade Acesso em 21.02.2014.

OLIVEIRA, R. M. Utilização de características de superfícies em madeiras tratadas termicamente. 2009. 127f. Tese (Doutorado em Física Aplicada) - Universidade de São Paulo, São Carlos, 2009.

PASCOAL, L. L. Rendimento de cortes preparados de carcaças de bovinos e formação de preço de venda. Porto Alegre, 2008. Tese (Doutorado em Produção Animal), UFRGS, 158p. Disponível em http://www.lume.ufrgs.br/bitstream/handle/10183/14339/000658451.pdf. Acesso em 01 de fevereiro de 2014.

PEREIRA, B. L. C.; CARNEIRO, A. C. O.; CARVALHO, A. M. M. L.; TRUGILHO, P. F.; MELO, I. C. N. A.; OLIVEIRA, A. C. Estudo da degradação térmica da madeira de Eucalyptus através de termogravimetria e calorimetria. Revista Árvore, Viçosa, v. 37, n. 3, p. 567-576, jun. 2013. 
PETROBRAS. Serviços: Densidade e poder calorífico superiores. Disponível em: http:// www.investidorpetrobras.com.br/pt/servicos/formulas-de-conversao/detalhe-formulas-de-conversao/densidade-e-poderes-calorificos-superiores.htm. Acesso em: 07.05.2014.

SILVA, R. B.; JÚNIOR, M. S.; SILVA, F. A. M.; FOLE, S. M. O tráfego de máquinas agrícolas e as propriedades físicas, hídricas e mecânicas de um Latossolo dos Cerrados. Revista Brasileira de Ciência do Solo, v. 27, p. 973-983, 2003.

YAMAMOTO, S. M.; SILVA SOBRINHO, A. G.; VIDOTTI, R. M.; HOMEM JUNIOR, A. C.; PINHEIRO, R. S. B.; BUZZULINI, C. Desempenho e digestibilidade dos nutrientes em cordeiros alimentados com dietas contendo silagem de resíduos de xe. Revista Brasileira de Zootecnia, Viçosa, v. 36, n. 4, p. 1131-1139, ago. 2007. 


\section{CARACTERÍSTICAS FÍSICAS DA FARINHA DE OSSOS CALCINADA}

Efraim Borges da Silva

Thassiane Telles Conde

Rosalvo Stachiw

No processo de calcinação, o tratamento térmico realizado pode promover a remoção de constituintes da matriz óssea. Assim, tem-se que temperaturas de $1000{ }^{\circ} \mathrm{C}$ garantem a total remoção do colágeno, dos proteoglicanos e de outras proteínas que fornecem flexibilidade a essas estruturas. Contudo, temperaturas menores podem ser utilizadas, economizando energia. É verificada acentuada perda de massa até 600 ${ }^{\circ} \mathrm{C}$, em função a perda de água e combustão da matéria orgânica contida nos ossos. Os picos de perda de massa e liberação de calor se situam entre 300-550 ${ }^{\circ} \mathrm{C}$ (CARUS; BENTO; BRAGANÇA, 2013), não se verificando perda significativa de massa acima de $800{ }^{\circ} \mathrm{C}$, o que indica a remoção completa da matéria orgânica $(\sim 34,8 \%)$. A perda de massa total de $35,1 \%$ se verifica quando temperaturas de $1000^{\circ} \mathrm{C}$ são utilizadas (CARUS; BENTO; BRAGANÇA, 2013).

Para essas condições $\left(800\right.$ e $\left.1000{ }^{\circ} \mathrm{C}\right)$, para temperatura de calcinação não resultam em diferenças granulométricas significativas do pó de osso (diâmetro médio em $\mu \mathrm{m}$ de 3,90 e 3,81 para 800 e $1000^{\circ} \mathrm{C}$, respectivamente) (CARUS; BENTO; BRAGANÇA, 2013) ou mesmo 2,7; 2,6; 2,6 e 3,3 $\mu$ m, respectivamente, para as temperaturas de $700,800,900$ e $1000{ }^{\circ} \mathrm{C}$ (GOUVÊA et al.,2007,2008) ou 4,16 «m (BÁLLVE;BRAGANÇA,2010).

Para o fabrico da farinha de ossos calcinada (FOC), tem-se que temperatura mais elevadas propiciam melhor eficiência na moagem de ossos bovinos, sendo reportados resultados semelhantes para calcinações a 700, 800, 900 e $1000{ }^{\circ} \mathrm{C}$ (CARUS; BENTO; BRAGANÇA, 2013). Esse material apresenta grande homogeneidade, apesar de sua origem natural, e as partículas apresentam estruturas equiaxiais (GOUVÊA et al., 2008). 
Não só a temperatura, mas também o ambiente oxidante é importante, uma vez que há dúvidas quanto à possibilidade da ocorrência de grupos cianeto adsorvidos na superfície das partículas (comprimentos de onda 2015 e $2204 \mathrm{~cm}^{-1}$ ), quando a calcinação ocorre em ambientes pouco oxidantes (GOUVÊA et al., 2008; CARUS; BENTO; BRAGANÇA, 2013). Contudo, há dúvida se tal registro se relaciona aos grupos carbonatos $\left(\mathrm{CO}\right.$ e $\left.\mathrm{CO}_{2}\right)$, uma vez que esses grupos apresentam maior estabilidade química com o fosfato de cálcio e se encontram nos mesmos comprimentos de onda que os cianetos, quando da análise cromatográfica (CARUS; BENTO; BRAGANÇA, 2013).

Em termos de composição com os resultados da difração de raios $\mathrm{X}$, esses grupos demonstram uma única fase cristalina, identificada como hidroxiapatita, $\mathrm{Ca}_{10}\left(\mathrm{PO}_{4}\right)_{6}(\mathrm{OH})$, para as amostras calcinadas a 800 e 1000 ${ }^{\circ} \mathrm{C}$, ou mesmo a $1200{ }^{\circ} \mathrm{C}$. Mas a maior influência da temperatura de calcinação é detectada em relação à área superficial, ou seja, quanto maior a temperatura menor a área superficial produzida (CARUS; BENTO; BRAGANÇA, 2013), o que pode representar uma facilidade para a obtenção de produto com elevada qualidade granulométrica.

Para área superficial específica, também podem ser relatados os valores de 5,09; 4,57; 4,41 e 2,56 $\mathrm{m}^{2} \mathrm{~g}^{-1}$, e densidade de 2,$91 ; 2,51 ; 2,52$ e 2,52 $\mathrm{g} \mathrm{cm}^{-3}$, respectivamente, para as temperaturas de 700, 800, $900 \mathrm{e}$ $1000{ }^{\circ} \mathrm{C}$ (GOUVÊA et al., 2008). Também com relação às propriedades físicas, encontra-se, em outras referências, relato de densidade de 0,89 $\mathrm{g}$ $\mathrm{cm}^{-3}$ e capacidade de retenção de água de 73,33\% (MATTAR; FRADE JÚNIOR; OLIVEIRA, 2013).

\section{Referências}

BALLVE, M. P; BRAGANCA, S. R. Novos fundentes para produção da porcelana de ossos. Cerâmica, São Paulo, v. 56, n. 337, p. 57-65, mar. 2010.

CARUS, L.A.; BENTO, L.; BRAGANCA, S. R..Avaliação do comportamento reológico de suspensões de ossos bovinos calcinados. Cerâmica,São Paulo,v.59,n.352,p.539-544, dez.2013.

GOUVEA, D.; BERNARD, S.; ALATRISTA, G. A. V.; TOFOLLI, S. M. Efeito da temperatura de calcinação nas propriedades de ossos bovinos para a fabricação de porcelana de ossos. Cerâmica, São Paulo, v. 54, n. 329, p. 423-428, mar. 2008. 
MATTAR, E.P. L.; FRADE JÚNIOR, E. F.; OLIVEIRA, E. (Eds.). Cinza de ossos-fósforo e cálcio para a agricultura. Cruzeiro do Sul, AC: UFAC, 2013. 25 p.

MIYAHARA, R. Y.; GOUVEA, D.; TOFFOLI, S. M. Obtenção e caracterização de cinza de ossos bovinos visando à fabricação de porcelana de ossos - bone china. Cerâmica, São Paulo, v. 53, n. 327, p. 234-239, set. 2007. 



\section{CARACTERÍSTICAS QUÍMICAS APÓS A CALCINAÇÃO}

Thassiane Telles Conde

Rosalvo Stachiw

A utilização de subprodutos industriais vindos do sistema agropecuário em propriedades rurais, tais como os ossos de animais mortos, pode proporcionar sustentabilidade em sistemas produtivos, pois contribui para a redução de recursos naturais esgotáveis, além de reduzir a dependência de insumos externos para a propriedade (GLIESSMAN, 2001).

Os ossos contêm compostos propícios para a produção de fertilizantes, como o cálcio, magnésio e fósforo, cujos valores estão apresentados na Tabela 1, podendo suprir a demanda do solo por esses minerais. Dentre eles, o fósforo merece destaque por ser um elemento cujas reservas conhecidas - que atendem a agricultura - podem se esgotar dentro de 100 anos (OSAVA, 2007) e sua presença no osso é de 12\% (OLIVEIRA e LEITE, 2005).

Tabela 1 - Composição química do osso

\begin{tabular}{lclc}
\hline Elemento & $\%$ & Elemento & $\%$ \\
\hline $\mathrm{Ca}$ & 83,84 & $\mathrm{CaO}$ & 73,48 \\
\hline $\mathrm{P}$ & 12,18 & $\mathrm{P}_{2} \mathrm{O}_{5}$ & 21,50 \\
\hline $\mathrm{Mg}$ & 0,88 & $\mathrm{MgO}$ & 1,17 \\
\hline $\mathrm{Si}$ & 0,67 & $\mathrm{SiO}_{2}$ & 1,29 \\
\hline Outros & 2,43 & Outros & 2,56 \\
\hline
\end{tabular}

Fonte: Adaptado de Oliveira e Leite (2005)

A maior presença de $\mathrm{CaO}$ no osso é deve-se à decomposição sofrida pela hidroxiapatita sob ação do calor. Outros produtos também são formados: o $\beta$-fosfato de tricálcio (TCP) e água. A reação de decomposição inicia-se a temperaturas superiores a $775{ }^{\circ} \mathrm{C}$ (KURITA et al., 1999), conforme a reação: 


$$
\mathrm{Ca}_{10}\left(\mathrm{PO}_{4}\right)_{6}(\mathrm{OH})_{2} \rightarrow 3 \mathrm{Ca}_{3}\left(\mathrm{PO}_{4}\right)_{2}+\mathrm{CaO}+\mathrm{H}_{2} \mathrm{O}
$$

Os ossos calcinados são importantes fontes de cálcio e fósforo. Entretanto, apresentam pequenas quantidades de outros íons em sua composição, como sódio, potássio e magnésio e, dependendo da lavagem, ferro $(\mathrm{Fe})$ proveniente do sangue (MIYAHARA; GOUVEA; TOFFOLI, 2007). Na Tabela 2, com base em GOUVEA et al. (2008), são apresentados esses valores químicos:

Tabela 2 - Análise química obtida através de fluorescência de raios $\mathrm{X}$ das amostras de ossos calcinados

\begin{tabular}{l|c|c|c|c}
\hline $\begin{array}{c}\text { Amostra } \\
\text { Óxidos (\%) }\end{array}$ & $700^{\circ} \mathrm{C}$ & $800^{\circ} \mathrm{C}$ & $900^{\circ} \mathrm{C}$ & $1000^{\circ} \mathrm{C}$ \\
\hline $\mathrm{CaO}$ & 55,3 & 55,3 & 55,3 & 55,6 \\
\hline $\mathrm{P}_{2} \mathrm{O}_{5}$ & 41,9 & 42,0 & 42,1 & 41,7 \\
\hline $\mathrm{Na}_{2} \mathrm{O}$ & 1,33 & 1,25 & 1,10 & 1,11 \\
\hline $\mathrm{MgO}$ & 1,11 & 1,11 & 1,12 & 1,13 \\
\hline $\mathrm{Al}_{2} \mathrm{O}_{3}$ & 0,01 & $<<$ & n.i. & n.i. \\
\hline $\mathrm{SiO}_{2}$ & 0,02 & 0,01 & n.i. & n.i. \\
\hline $\mathrm{SO}_{3}$ & 0,13 & 0,16 & 0,18 & 0,18 \\
\hline $\mathrm{Cl}$ & 0,10 & 0,13 & 0,07 & 0,06 \\
\hline $\mathrm{K}_{2} \mathrm{O}$ & 0,40 & 0,03 & 0,02 & 0,02 \\
\hline $\mathrm{ZnO}$ & 0,02 & 0,02 & 0,02 & 0,02 \\
\hline $\mathrm{SrO}$ & 0,06 & 0,06 & 0,06 & 0,07 \\
\hline $\mathrm{BaO}$ & 0,02 & $<$ & n.i. & 0,10 \\
\hline$<<-$
\end{tabular}

$<<=$ traços e n.i. = não identificado. Fonte: Adaptado de Gouveia et al. (2008).

Já a farinha de osso calcinada é o resultado da pirólise de ossos a altas temperaturas, sendo rica em fósforo. Seu potencial é expressivamente maior que as rochas fosfáticas nacionais e seus concentrados, contendo cerca de $40 \%$ de $\mathrm{P}_{2} \mathrm{O}_{5}$ (OOI, 2007).

Avelar et al. (2009) apresentam dados que ressaltam que a farinha de ossos possui predominância de Apatita $\left(\left(\mathrm{Ca}_{5}\left(\mathrm{PO}_{4}\right)_{3}(\mathrm{Cl}, \mathrm{F}, \mathrm{OH})\right)\right.$, quando analisadas suas características minerais, e demonstram ainda, por meio da Tabela 3, a concentração de alguns elementos que fazem parte de sua constituição. 
Tabela 3 - Dados diversos Farinha de Ossos

\begin{tabular}{|c|c|c|c|c|c|}
\hline \multirow{4}{*}{$\begin{array}{c}\text { Características } \\
\text { Minerais } \\
\text { Concentrações } \\
\text { de } \mathrm{P}, \mathrm{Ca}, \text { e } \mathrm{SiO}_{2} \mathrm{e} \\
\text { solubilidade dos } \\
\text { produtos em ácido } \\
\text { cítrico a } 2 \% \text { e a } 10 \%\end{array}$} & \multicolumn{5}{|c|}{$\begin{array}{c}\text { Apatita }\left(\mathrm{Ca}_{5}\left(\mathrm{PO}_{4}\right)_{3}(\mathrm{Cl}, \mathrm{F}, \mathrm{OH})\right)= \\
\text { Predominante }(\mathrm{c}>30 \%)\end{array}$} \\
\hline & $\mathrm{P}=14,4$ & \multirow{2}{*}{\multicolumn{2}{|c|}{$\begin{array}{c}\mathrm{Ca}=36,7 \\
\pm 0,4\end{array}$}} & \multirow{2}{*}{\multicolumn{2}{|c|}{$\begin{array}{c}\mathrm{SiO}_{2}=9,92 \\
\pm 1,00\end{array}$}} \\
\hline & $\pm 0,3$ & & & & \\
\hline & $\begin{array}{l}\text { Solubili- } \\
\text { dade áci- } \\
\text { do cítrico }\end{array}$ & \multicolumn{2}{|c|}{$2 \%=23 \pm 4$} & \multicolumn{2}{|c|}{$10 \%=32 \pm 3$} \\
\hline $\begin{array}{l}\text { Concentrações de } \mathrm{Na} \text {, } \\
\text { Zn, Fe, Co. } \\
\text { (dados em mg.g } \text { - }^{-1} \text { ) } \\
\text { e S em (\%) }\end{array}$ & $\begin{array}{c}\mathrm{Na}= \\
8650 \pm \\
198\end{array}$ & $\begin{array}{c}\mathrm{Zn}= \\
239,0 \pm \\
8,5\end{array}$ & $\begin{array}{c}\mathrm{Fe}= \\
12450 \pm \\
523\end{array}$ & $\mathrm{Co}=0,7$ & $S=0,30$ \\
\hline
\end{tabular}

Fonte: Adaptado de Avelar et al. (2009)

Durante a análise semi-quantitativa do calcinado de osso bovino por fluorescência de raios $\mathrm{X}$, obteve-se resultado de alto teor de fósforo e oxigênio e médio teor de cálcio, o que pode ser justificado pelo fato de o calcinado consistir em hidroxiapatita, material com $40 \%$ de $\mathrm{P}_{2} \mathrm{O}_{5}$, conforme verificado pela difração de raios-Xe espectroscopia de infravermelho.Já na espectrometria de absorção atômica, os valores obtidos para a concentração de nutrientes e metais no calcinado de osso bovino, mostram percentuais de: $27,73 \%$ para $\mathrm{Ca}, 0,60 \%$ para $\mathrm{Mg}, 1,84 \%$ para $\mathrm{Fe}$ e $1,47 \%$ para $\mathrm{Al}$, comprovando mais uma vez o alto teor de cálcio. Todavia, o mínimo exigido pelo Ministério da Agricultura, Pecuária e Abastecimento é de 16\% p/p (SANTOS, 2012).

A farinha de osso calcinada, quando lavada adequadamente para a retirada de sangue, é isenta de metais que interferem negativamente na adsorção de fósforo pela planta, como o ferro e o alumínio. Além disso, as rochas fosfáticas possuem alta concentração de materiais de ganga, ou seja, materiais extraídos juntamente com o mineral desejado, podendo ser considerados como material de rejeito, resultando em maior volume resíduos, o que demonstra mais uma vez o aspecto positivo em relação ao uso do material alternativo (SANTOS, 2012).

A farinha de ossos também foi estudada para suplementação alimentar de equinos, visto que os valores de biodisponibilidade (absorção real 
do fósforo) indicaram que essa fonte é adequada para o consumo desses animais (FURTADO et al., 2000).

Esse produto demonstra ter, ainda, excelente potencial como adubo, apesar de sua reação ser um pouco lenta em temperaturas frias e temperadas, mas em temperaturas elevadas a reação ocorre logo após alguns dias depois do plantio (MALAVOLTA et al., 2000).

Diante do exposto, torna-se claro que o calcinado de osso bovino possui constituintes químicos que propiciam a sua utilização como fertilizante alternativo para o desenvolvimento de culturas agrícolas.

\section{Referências}

AVELAR, A.C.; FERREIRA, W.M.; BRITO, W.; MENEZES, M.A.B.C. Composição mineral de fosfatos, calcário e farinha de ossos usados na agropecuária brasileira. Archivos de Zootecnia, v. 58, n. 224, p.737-740, 2009.

FURTADO, C. E.; TOSI, H.; VITTI, D. M. S. S. Disponibilidade Biológica do Fósforo de Diferentes Fontes para Equinos em Crescimento. Pesquisa Agropecuária Brasileira. Brasília, v.35, n.5, p. 1011-1016, 2000.

GLIESSMAN, S. R. Agroecologia: processos ecológicos em agricultura sustentável. Porto Alegre: EdUFRGS, 2001.

GOUVEA, D.; BERNARD, S.; ALATRISTA, G.A.V.; TOFOLLI, S. M. Efeito da temperatura de calcinação nas propriedades de ossos bovinos para a fabricação de porcelana de ossos. Cerâmica, São Paulo, v. 54, n. 329, p. 423-428. 2008.

KURITA, T.; OTSUKA, N.; ASAGA, K.; FUGIMOTO, H. Measurement of Pore Structure of Bone China Body during a Heating Process by Mercury Intrusion Porosimeter. Journal of the Ceramic Society of Japan. v. 107, n. 1245, p. 476-481. 1999.

MALAVOLTA, E.; PIMENTEL-GOMES, F.; ALCARDE, J. C. Adubos \& adubações. São Paulo: AMPUB, 2000.

MATTAR, E. P. L.; FRADE JÚNIOR, E. F.; OLIVEIRA, E. (Eds.). Cinza de ossos-fósforo e cálcio para a agricultura. Cruzeiro do Sul, AC: UFAC, 2013.25 p.

MIYAHARA, R. Y.; GOUVEA, D.; TOFFOLI, S. M. Obtenção e caracterização de cinza de ossos bovinos visando à fabricação de porcelana de ossos - bone china. Cerâmica, São Paulo, v. 53, n. 327, p. 234-239. 2007.

OLIVEIRA, F. M. da S.; LEITE, J.Y.P. Caracterização de Matérias-Primas e Resíduos de Osso Visando um Produto Cerâmico. 23 CONGRESSO BRASILEIRO DE ENGENHARIA SANITÁRIA E AMBIENTAL, 2005. 
OOI, C. Y.; HAMDI, M.; RAMESH, S. Properties of hydroxyapatite produced by annealing of bovine bone. Ceramics International, v. 33, p. 1171-1177, 2007.

OSAVA, M. Agricultura diante da grave escassez de fosfato. Revista Fórum, [S. 1.] 2007.

SANTOS, C.M.F. Obtenção de fertilizante fosfatado de alta solubilidade a partir de calcinado de osso bovino. 2012. Dissertação (Mestrado) - Universidade Federal de Minas Gerais. Programa de Pós-graduação em Engenharia Metalúrgica e de Minas. Belo Horizonte. 2012. 



\title{
6. AVALIAÇÃO QUALITATIVA DA FARINHA DE OSSOS CALCINADA
}

\author{
Diego Boni \\ João Batista Dias Damaceno \\ Lindomar Alves de Souza \\ Tiago Gyovani de Melo Baldino
}

A farinha de ossos está sendo usada como fonte de nutrientes para plantas forrageiras. Além de ser uma alternativa para a nutrição fosfatada das plantas, a farinha de ossos pode representar um bom negócio tanto para quem a produz como para quem a comercializa; contudo, ainda não há muitos trabalhos sobre o assunto, em decorrência de sua produção em pequena escala, como acontece no contexto da agricultura familiar. Em Rolim de Moura-RO, com a aquisição de ossos, alguns empreendedores queimam esse substrato a fim de produzir farinha de ossos. Nesse processo, podem ser observadas diferentes tonalidades de cinza nos produtos comercializados (FERREIRA; BALBINO, 2014). A variação de cor é, no entanto, um indicativo relacionado à qualidade química do produto.

Uma pilha de ossos incinerados, sem controle local, pode se queimar de diferentes maneiras, e as variações geradas também podem se relacionar com sua anatomia. De maneira geral, os ossos posicionados mais perifericamente queimam de formas irregulares em relação àqueles posicionados no centro da fogueira. Observa-se a presença de cores escuras, ou mesmo preto, em contraste com variações de cinza e até branco, mais facilmente observadas na parte central do volume queimado (Figura 1).

As diferenças de cor estão relacionadas à oxidação da matéria orgânica, uma vez que sua queima ocorre na temperatura de $500^{\circ} \mathrm{C}$. Nessa condição, parte de seus produtos de decomposição deve permanecer aderida à superfície do material, na forma de material carbonizado, gerando uma cor negra, a qual vai ser gradativamente eliminada, à medida que a temperatura se eleva (MYIAHARA; GOUVEA; TOFFOLI, 2007). 
Figura 1 - Ossos de bovinos após a queima não controlada (A); aspecto dos diferentes níveis de calcinação (B); amostras separadas e moídas por diferença de cor $(C)$ e protótipo de carta de valor para avaliação qualitativa da farinha de ossos calcinada em condições de queima não controlada (D)

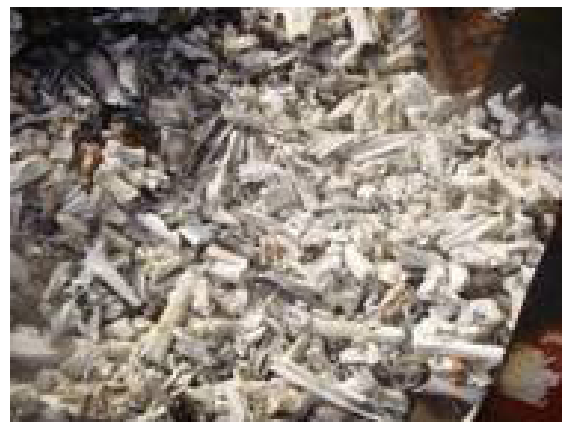

A

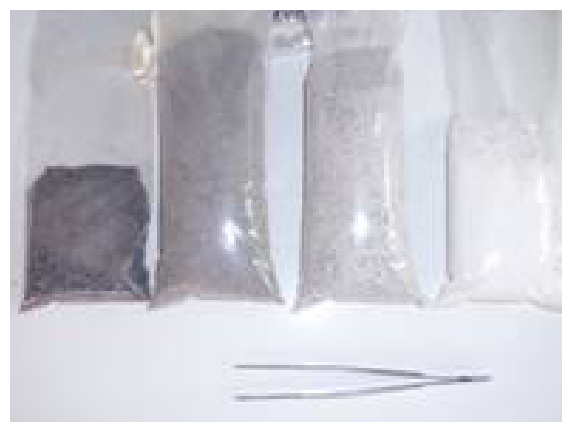

C

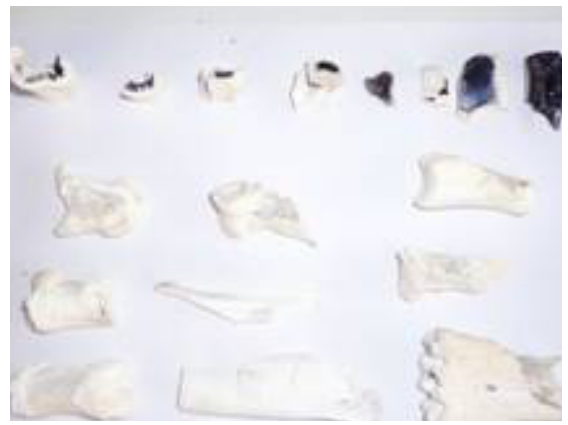

B

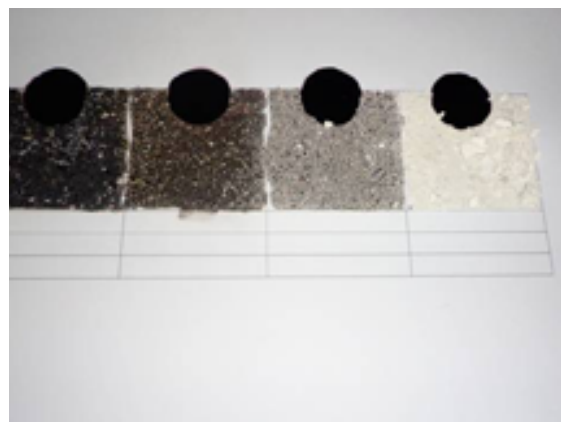

$\mathrm{D}$

Fonte: FERREIRA; BALBINO, 2014

Observa-se que quanto mais brancos mais facilmente quebradiços os ossos se tornam. Quimicamente, a farinha de ossos calcinada é rica em fósforo e cálcio, mas seus teores variam em função do grau de calcinação. $\mathrm{Na}$ literatura, cita-se que a farinha de ossos calcinada possui em torno de 15\% de P total (MATTAR; FRADE JÚNIOR; OLIVEIRA, 2013), sendo 0,26\% solúvel em água (FERRO; CUNHA; FERREIRA, 2013) e 10\% solúvel em ácido cítrico; para o cálcio, relata-se 33\% em sua composição. O pH do material em água é de 9,94 (MATTAR; FRADE JÚNIOR; OLIVEIRA, 2013). 
Em relação à variabilidade observada nesse material, como proposta desenvolveu-se um protótipo (carta de cor) para avaliação da qualidade química da farinha de ossos calcinada obtida por queima não controlada. Quatro diferentes tonalidades de branco-preto foram observadas. Às cores escuras e ao preto foram atribuídos os valores de zero e 1 , em relação à carta de Munsell, o mesmo procedimento feito para o cinza escuro (1 a 2), cinza claro (4 a 5) e o branco ( 9 a 10). Nas variáveis analíticas, a maior amplitude de variação obtida se deu com o poder de neutralização $(10,6$ = 27,4 -16,8), sendo a média aritmética e desvio médio de 21,85 e 4,20, respectivamente. A menor amplitude ocorreu com o óxido de Magnésio $(0,15=0,97-0,82)$, sendo sua média de 0,89 e seu desvio médio de 0,052. Amplitudes importantes foram observadas em relação ao \%Fósforo - $\mathrm{P}_{2} \mathrm{O}_{5}$ total $(8,2=38,8=30,6)$ e ao óxido de Cálcio\% ( $9=48$ - 39), ficando suas médias em 35,8 e 44,55, respectivamente. Os teores de $\mathrm{P}_{2} \mathrm{O}_{5}$ total e de $\mathrm{CaO}$ são correlacionados positivamente (FERREIRA; BALBINO, 2014).

Para o teor de PRNT, obteve-se média de 14,80 com desvio de 2,45. Contudo, esse comportamento é dependente do grau de moagem do material, o qual, para este estudo, não recebeu tratamento padronizado (FERREIRA; BALBINO, 2014).

\section{Referências}

FERREIRA, E; BALBINO, T. Carta de cores para a avaliação qualitativa da farinha de ossos calcinada. Instituto Nacional de Propriedade Industrial, Diretoria de Patentes. Submetido em 07.04.2014. Protocolo: BR2020140083923.

MATTAR, E. P. L.; FRADE JÚNIOR, E. F.; OLIVEIRA, E. (Eds.). Cinza de ossos fósforo e cálcio para a agricultura. Cruzeiro do Sul, AC: UFAC, 2013. 25 p.

MIYAHARA, R. Y.; GOUVEA, D.; TOFFOLI, S. M.. Obtenção e caracterização de cinza de ossos bovinos visando à fabricação de porcelana de ossos - bone china. Cerâmica, São Paulo, v. 53, n. 327, p. 234-239, set. 2007. 



\section{SOLUBILIZAÇÃO DE FOSFATO DA FARINHA DE OSSOS CALCINADA}

Elvino Ferreira

Emanuel Maia

Jairo Rafael Machado Dias

Jerônimo Vieiria Dantas Filho

Jucilene Cavali

Marisa Pereira Matt

Marlos Oliveira Porto

A farinha de ossos calcinada (34\% $\mathrm{P}_{2} \mathrm{O}_{5}$ total, $10 \%$ de $\mathrm{P}$ solúvel em ácido cítrico e $33 \%$ de Cálcio) pode ser comparada ao termofosfato magnesiano (18\% $\mathrm{P}_{2} \mathrm{O}_{5}$ total, $7 \%$ de $\mathrm{P}$ solúvel em ácido cítrico e 20\% de Cálcio) como fonte de fósforo de uso comum na agricultura orgânica (MATTAR; FRADE JÚNIOR; OLIVEIRA, 2013). No sentido de promover uma ciclagem mais eficiente de fósforo nos sistemas agropecuários, deve ser pesquisada uma maneira de atender as diferentes necessidades das plantas em relação às suas exigências de fósforo. Em termos de manejo de fosfatos de baixa reatividade, tem-se que seus efeitos podem não ser apresentados em um primeiro ano, sendo manifesto residualmente a partir do segundo ou terceiro ano após sua aplicação. Esse efeito está relacionado ao tempo de exposição das partículas ao ambiente ácido do solo. A falta ou o excesso de solubilidade podem ser igualmente indesejáveis, particularmente em solos tropicais (NOVAIS; SMYTH; NONES, 2007).

Em trabalho objetivando comparar diferentes extratores comumente usados em testes de solubilidade de fósforo, foram utilizadas seis fontes de fosfato: fosfato bicálcico, fosfato monoamônico, fosfato supertriplo, farinha de ossos calcinada (FOC), farinha de ossos autoclavada e fosfato de rocha de Araxá, em relação aos extratores: água, ácido cítrico nas concentrações de $2 \%, 10 \%, 20 \%$ e $30 \%$; ácido clorídrico na concentração de $0,5 \%(\mathrm{HCl})$ e citrato neutro de amônio (CNA). Os resultados estão apresentados na 
Tabela 1 a seguir e os procedimentos metodológicos podem ser obtidos em Duarte et al., (2003).

Tabela 1 - Solubilidade de fósforo de fontes de variadas origens em diversos extratores

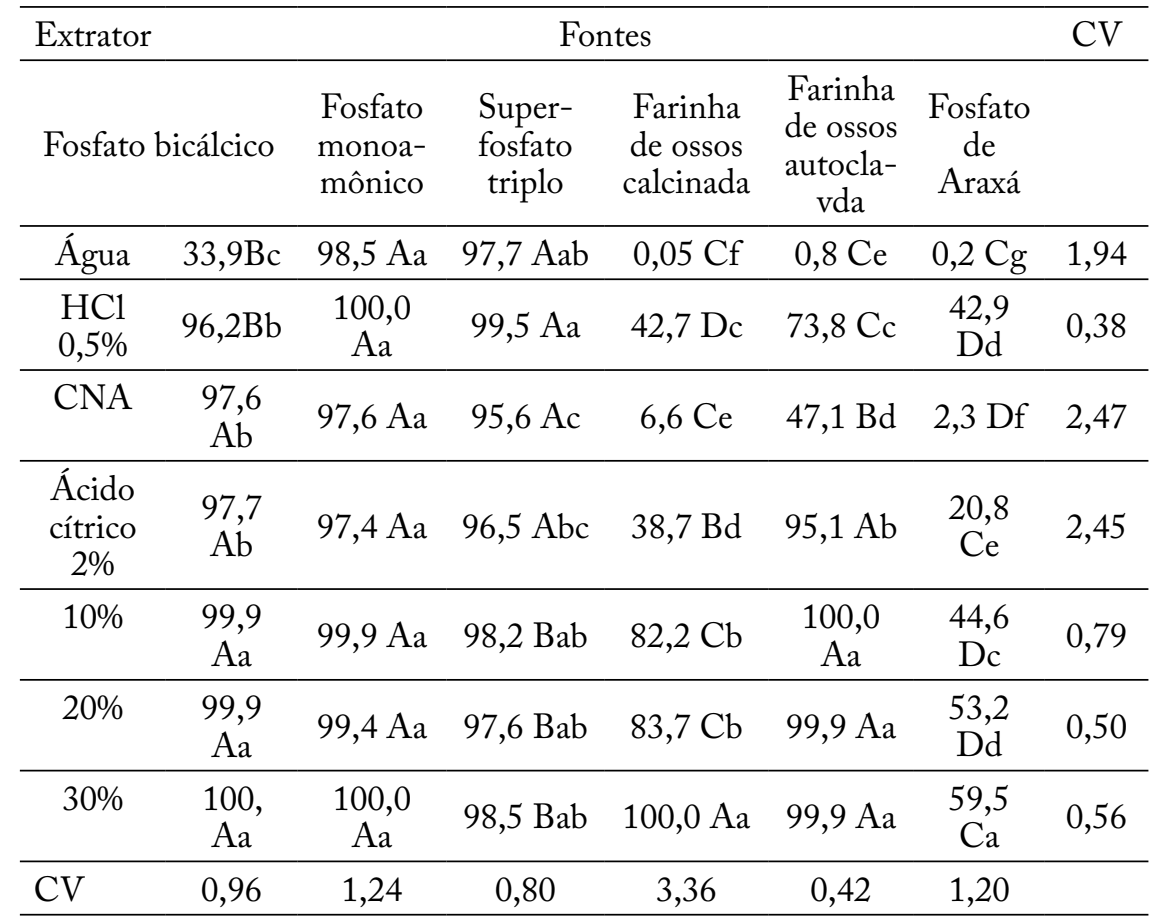

CNA: citrato neutro de amônio. Valores seguidos por letras maiúsculas distinta na mesma linha ou minúsculas distintas na mesma coluna diferem entre si pelo teste $\mathrm{SNK}(\mathrm{P}<0,05)$.

Fonte: DUARTE et al., (2003)

De uma maneira geral, os tratamentos ácidos potencializaram a solubilização do fósforo atingindo níveis máximos ou próximos a esse. Para as fontes de menor solubilidade (Farinha de ossos calcinada, farinha de ossos autoclavada e fosfato de Araxá), os resultados de solubilidade se apresentaram com maior variabilidade, o que pode representar indicativo de estudo quando a ajustes tecnológicos, a fim de esse elemento estar disponível para forrageiras de diferentes exigências nutricionais quanto ao elemento.

Apesar de a FOC ter potencial emprego na adubação de pastagens, por possibilitar o fornecimento de $\mathrm{P}$ para as forrageiras em um período mais longo, seu tratamento em ambiente ácido pode disponibilizar o $\mathrm{P}$, 
mudando sua dinâmica no sistema solo-planta. Em avaliação de solubilidade, quando foram testadas diversas fontes de $\mathrm{P}$, os resultados com fontes de baixa solubilidade, como o fosfato de Araxá, a farinha de ossos calcinada e a farinha de ossos autoclavada resultaram em solubilização de 42,9\%; $42,7 \%$ e 73,8\% quando da utilização do ácido clorídrico (0,5\%), respectivamente. Com o emprego do ácido acético (30\%), obteve-se maiores níveis de solubilidade (59,5\%; 100\% e 99,9\%) (DUARTE et al., 2003). Portanto, os desenvolvimentos de tecnologias que aproveitem de forma racional o uso da farinha de ossos calcinada representam uma importante via de reciclagem de nutrientes para o sistema de pastagem, ainda mais considerando que as reservas comerciais de fosfato se esgotem entre 60 e 100 anos (OSAVA, 2007).

Outro questionamento em relação ao emprego do tratamento ácido para solubilização de fósforo para forrageiras estaria relacionado a qual ácido seria o mais apropriado e qual o seu efeito para a acidez residual desse material, objetivando sua aplicação ao solo. Assim, tomaram-se iguais quantidades de farinha de ossos, em três repetições, nas quais foram adicionadas as concentrações de 10\%, 25\%, 50\% e 100\% de vinagre comercial e $\mathrm{HCl} \mathrm{PA}$. Os reagentes foram misturados $(\mathrm{p} / \mathrm{v})$, deixados em repouso por duas horas, sendo levados para estufa de ventilação forçada para desidratação. Após cinco dias, verificou-se que Rendimento Relativo\% ([massa final/ massa inicial $]$ x 100) para os tratamentos feitos com vinagre comercial ficaram em média de $98,9 \%$, enquanto aqueles que foram submetidos ao $\mathrm{HCl}$ tiveram sua massa aumentada (Tabela 2). Para o tratamento com $10 \% \mathrm{HCl}$, obteve-se $111,6 \%$ de rendimento relativo; já para o com 100\% HCl, obteve-se 159,7\% (MATT, TCC em andamento). 
Tabela 2 - Avaliação da acidez residual em farinha de ossos calcinada submetida a tratamento ácido

\begin{tabular}{lccccc}
\hline Reagente & $\begin{array}{c}\text { Concentração } \\
(\%)\end{array}$ & $\begin{array}{c}\text { Massa final } \\
(\mathrm{g})\end{array}$ & $\begin{array}{c}\text { Rendimento } \\
\text { Relativo (\%) }\end{array}$ & $\mathrm{pH}$ final & $\begin{array}{c}\text { Redução } \\
\text { de pH }\end{array}$ \\
\hline Vinagre & 10 & 49,00 & 98,0 & 6,97 & 3,78 \\
\cline { 2 - 6 } comercial & 25 & 49,47 & 98,9 & 7,66 & 3,09 \\
\cline { 2 - 6 } & 50 & 49,46 & 98,9 & 7,55 & 3,20 \\
\hline \multirow{nyyyyy}{*}{ HCl PA } & 100 & 49,75 & 99,5 & 7,57 & 3,18 \\
\cline { 2 - 6 } & 10 & 55,83 & 111,6 & 4,71 & 6,04 \\
\cline { 2 - 6 } & 25 & 63,96 & 127,9 & 2,57 & 8,18 \\
\cline { 2 - 6 } & 50 & 73,01 & 146,0 & 2,05 & 8,70 \\
\hline
\end{tabular}

Rendimento Relativo\% $=($ massa final $/$ massa inicial $) \times 100 ;$ Massa inicial 50g; $\mathrm{pH}$ inicial $=$ 10,75; Redução de $\mathrm{pH}=\mathrm{pH}$ inicial $-\mathrm{pH}$ final.

$\mathrm{O} \mathrm{pH}$ inicial da farinha de ossos calcinada era de 10,6, o qual foi reduzido com os tratamentos ácidos. Para as concentrações de 10, 25, 50 e $100 \%(\mathrm{p} / \mathrm{v})$ de vinagre comercial, obteve-se 6,97; 7,66; 7,55 e 7,57 como $\mathrm{pH}$ final, respectivamente. Com o uso de $\mathrm{HCl}$, nas mesmas concentrações, os níveis finais de $\mathrm{pH}$ foram menores: 4,71; 2,57; 2,05 e 2,13, respectivamente. É interessante ressaltar que, na dinâmica de adsorção do fósforo no solo, observa-se uma ordem preferencial partindo do fosfato $>$ arseniato $>$ selenito $=$ molibdato $>$ sulfato $=$ fluoreto $>$ cloreto $>$ nitrato (NOVAIS, SMYTH, NUNES, 2007). Já considerando ácidos orgânicos, o solo pode adsorvê-los com grande energia, proporcionando competição com os sítios de adsorção de fósforo e aumentando, com isso, sua disponibilidade para as plantas. Moléculas com maior quantidade de grupos funcionais $\mathrm{OH}$ e $\mathrm{COOH}$ são mais efetivas na competição com os sítios de adsorção que aquelas com menor número. Assim, por exemplo, o ácido málico $(1 \mathrm{OH}$ e $2 \mathrm{COOH})$ foi mais efetivo que o ácido acético $(1 \mathrm{COOH})$ em reduzir a adsorção de fósforo no solo (NOVAES, SMYTH, NUNES, 2007). Certamente, nessa dinâmica, a atuação da microbiologia do solo quanto à mineralização desses elementos deve ser considerada.

Por esse ensaio preliminar, pode-se perceber o potencial de uso do tratamento ácido - para gerar produtos com $\mathrm{pH}$ adequado para seu emprego em forrageiras - que pode representar, também, uma reserva de 
fósforo a ser solubilizada residualmente. No tocante a possíveis ajustes, o maior rendimento relativo observado com o tratamento da farinha de ossos calcinada com $\mathrm{HCl}$ PA está relacionado a sua maior força iônica, liberando mais cálcio da hidroxiapatita e, com isso, possibilitando sua reação com o oxigênio do ar. Essa massa final se apresentou com consistência umidecida, enquanto aquela tratada com vinagre comercial, não.

\section{Referências}

DUARTE, H. C.; GRAÇA, D. S.; BORGES, F. M. O.; DI PAULA, O. J. Comparação de métodos "in vitro" para determinação da biodisponibilidade de fósforo. Arquivos Brasileiros de Medicina Veterinária e Zootecnia, Belo Horizonte, v. 55, n. 1, p. 80-84, fev. 2003.

MATTAR, E.P. L.; FRADE JÚNIOR, E. F.; OLIVEIRA, E. (Eds.). Cinza de ossos-fósforo e cálcio para a agricultura. Cruzeiro do Sul, AC: UFAC, 2013. 25 p.

NOVAES, R. F.; SMYTH, T. J.; NUNES, F. N. VIII - Fósforo (p. 471-550) In: NOVAIS et al. (Eds.). Fertilidade do Solo. Viçosa, MG. Sociedade Brasileira de Ciência do Solo. 2007. 1017 p.: Il.

OSAVA, M. Agricultura diante da grave escassez de fosfato. Revista Forum, [S.1.] 2007. Disponível em: http://www.revistaforum.com.br/sitefinal/EdicaoNoticiaIntegra.asp?id_artigo=1402. Acesso em: 23 nov. 2013. 



\section{NECESSIDADES DAS FORRAGEIRAS QUANTO AO CÁLCIO}

Aderson Cristian Bergamin

O cálcio tem grande importância no desenvolvimento das raízes, na formação da estrutura da planta e também no metabolismo de outros compostos, como o nitrogênio, por exemplo (WERNER, 1994). Seu fornecimento ao solo se dá através da calagem (aplicação de calcário) e gera a elevação do $\mathrm{pH}$, consequentemente aumentando a disponibilidade de fósforo e molibdênio que, em $\mathrm{pH}$ muito baixo, ficam em formas não assimiláveis pelas plantas. Também neutraliza alumínio, manganês e ferro que, em $\mathrm{pH}$ baixo, podem estar em formas e quantidades tóxicas (WERNER, 1994).

Em relação à acidez do solo, as plantas forrageiras se comportam de forma variada, já que algumas conseguem se estabelecer e produzir em solos ácidos, e outras, não. Os diferentes solos necessitam de diferentes quantidades de calcário para sua correção, em função de seu nível de argila e/ou matéria orgânica, comparativamente a solos arenosos.

Em relação às forrageiras, elas podem ser divididas em grupos, conforme as exigência por saturação de bases, apresentados na Tabela 1, coligidos por Werner (1994) e Cantarutti et al., (1999). 
Tabela 1 - Agrupamento das forrageiras em função do manejo de produção e nível de saturação de bases

\begin{tabular}{|c|c|}
\hline \multirow[t]{3}{*}{$\begin{array}{l}\text { Grupo } 1(\mathrm{~V}=60 \%) \text { ou } \\
\text { nível tecnológico alto } \\
\text { ou intensivo }\end{array}$} & $\begin{array}{l}\text { Gramíneas: (Pennisetum): capim elefante, Came- } \\
\text { ron, Napier, Pennisetum híbrido; Tiftons (Cynod- } \\
\text { don): coast-cross, estrela; (Panicum): Colonião, Ven- } \\
\text { cedor, Centenário, Tobiatã, Tanzânia, Green-panic, } \\
\text { etc; (Brachiaria brizantha): braquiarão ou Marandú; } \\
\text { (Chloris gayana): Rhodes; (Hyparrhenia rufa): Jaraguá; } \\
\text { (Digitaria decumbens): pangola, }\end{array}$ \\
\hline & $\begin{array}{l}\text { (Também quando usados para fenação e capineira de- } \\
\text { vido à grande remoção de nutrientes) }\end{array}$ \\
\hline & $\begin{array}{l}\text { Leguminosas: (Medicago sativa): alfafa; (Leucena leu- } \\
\text { cocephala): leucena; (Neonotonia wightii): soja perene. }\end{array}$ \\
\hline \multirow{3}{*}{$\begin{array}{l}\text { Grupo } 2(\mathrm{~V}=40 \%) \text { ou } \\
\text { nível tecnológico médio }\end{array}$} & $\begin{array}{l}\text { Gramíneas: Napier, pangola, coast-cross, estrela, } \\
\text { Green panic (para pastejo), braquiárias, Jaraguá, Tan- } \\
\text { zânia, Mombaça, Marandú, (Melinis minutiflora): gor- } \\
\text { dura; (Brachiaria decumbens): braquiaria decumbens; } \\
\text { (Setaria sphacelata): setária; (Andropogon gayanus): an- } \\
\text { dropogon; }\end{array}$ \\
\hline & $\begin{array}{l}\text { Para braquiárias, setária e gordura, quando V\% >30 } \\
\text { não seria necessário elevá-la a } 40 \text {, a não ser que se des- } \\
\text { tinem para fenação. Para os demais, quando se planeja } \\
\text { um sistema de manejo intensivo com elevadas ferti- } \\
\text { lizações com adubos nitrogenados acidificantes (ex., } \\
\left(\mathrm{NH}_{4}\right)_{2} \mathrm{SO}_{4} \text {; ureia...), deve-se prevenir a acidificação, } \\
\text { adotando-se V\% } 60 \text {. }\end{array}$ \\
\hline & $\begin{array}{l}\text { Legunimosas: Leucena, soja perene, (Centrosema pu- } \\
\text { bescens): centrosema; (Macroptilium atropurpureum): } \\
\text { siratro; (Arachis pintoi): amendoim forrageiro; (Ca- } \\
\text { lopogonio mucunoides): calopogônio; (Cajanus cajan): } \\
\text { guandu; (Desmodium): desmodium; (Galactia striata): } \\
\text { galáctia; (Pueraria phaseoloides): Kudzú, e os (Stylosan- } \\
\text { thes): estilosantes. }\end{array}$ \\
\hline \multirow{2}{*}{$\begin{array}{l}\text { Grupor } 3 \text { ou nível } \\
\text { tecnológico baixo ou } \\
\text { extensivo }\end{array}$} & $\begin{array}{l}\text { Gramíneas: braquiaria IPEAN, braquiarinha autra- } \\
\text { liana, (Brachiaria humidicola): humidicola; (Brachiaria } \\
\text { dictyoneura): dictioneura; Andropogon, Jaraguá, Gor- } \\
\text { dura, (Paspalum notatum): pensacola, batatais }\end{array}$ \\
\hline & $\begin{array}{l}\text { Leguminosas: estilosantes Mineirão, estilosantes ban- } \\
\text { deirantes, amendoim forrageiro, Kudzú, galactia, ca- } \\
\text { lopogônio. }\end{array}$ \\
\hline
\end{tabular}

Fonte: Coligido de Werner (1994, p. 115); Cantarutti et al., (1999, p.333) 
É interessante que o calcário seja incorporado a fim de melhorar sua reação com o solo.Para formação, recomenda-se que metade da dose seja aplicada antes da aração, e a outra metade, antes da gradagem. Em função de seu poder relativo de neutralização total (PRNT), faz-se necessária a espera de 60 dias ou mais, antes de se promover as adubações fosfatadas e nitrogenadas para o plantio do pasto. Para pastagem já formada, recomenda-se seu rebaixamento à aplicação superficial do calcário (se possível com alguma escarificação), no início do período das águas (GOMIDE,1994; WERNER,1994).

Em relação às dosagens, não se deve aplicar doses maiores que 3 toneladas por hectare. Se necessário, parcelá-las em dois anos consecutivos (GOMIDE, 1994). Em relação à dinâmica de nutrientes para as plantas, registra-se na literatura que a calagem prévia dos solos não alterou, de maneira consistente, a velocidade e a magnitude de adsorção de fósforo pelo solo (NOVAIS, SMYTH, NUNES, 2007, p. 496); assim, a construção de um novo compartimento de $\mathrm{P}$, com acesso direto das raízes, representaria uma alternativa tecnológica para a reciclagem e uso racional desse nutriente.

Em virtude da adaptação de algumas forrageiras a solos ácidos, o uso de calcário deve ser considerado não como corretivo do solo, mas como fonte de cálcio e magnésio, para o que é suficiente pequena quantidade de aproximadamente 250 a $500 \mathrm{~kg} \mathrm{ha}{ }^{-1}$ (GOMIDE, 1994). Alguns níveis de cálcio no solo e seu teor na forragem são apresentados na Tabela 2.

Tabela 2 - Saturação crítica de cálcio e alumínio de um Latossolo para o cultivo de gramíneas forrageiras e respectivas concentrações críticas internas de cálcio

\begin{tabular}{lccc}
\hline \multirow{2}{*}{ Espécie } & \multicolumn{2}{c}{ Saturação crítica } & Concentração crítica $\mathbf{C a} \%$ \\
\cline { 2 - 3 } & $\mathbf{C a} \%$ & $\mathbf{A l} \%$ & \\
\hline Pennisetum purpureum & 29 & 60 & 0,40 \\
\hline Panicum maximum & 24 & 72 & 0,60 \\
\hline Digitaria decumbens & 20 & 74 & 0,42 \\
\hline Brachiaria decumbens & 17 & 77 & 0,34 \\
\hline Melinis minutiflora & 12 & 86 & 0,32 \\
\hline Andropogon gayanus & 13 & 85 & 0,30 \\
\hline Brachiaria humidicola & 9 & 89 & 0,20 \\
\hline
\end{tabular}

Fonte: Gomide (1994, p. 460). 
A complexa relação dos nutrientes com o sistema solo-planta pode ser representada pelo estudo que avaliou a resposta da Brachiaria decumbens às doses e fontes de fósforo, na presença de três doses de calcário, em Latossolo vermelho escuro. Com ele, obtiveram-se aumentos na produção em MS até o nível mais elevado de $\mathrm{P}$, sendo que os maiores acréscimos foram obtidos entre os dois níveis mais baixos, 38 e $150 \mathrm{~kg} \mathrm{ha}^{-1} \mathrm{P}$. Ainda relatam os autores que a calagem prejudicou a produção de MS, no primeiro ano, nas parcelas que receberam fosfato de Araxá, desaparecendo esse efeito com o tempo. Em termos de produção total de MS, o superfosfato simples e o termofosfato magnesiano (Yoorin) mostraram melhor desempenho do que o hiperfosfato (fosfato natural de Gafsa, Marrocos) e o fosfato natural de Carolina no Norte (EUA), sendo as quatro fontes superiores ao fosfato de Araxá (LOBATO; KORNELIUS; SANZONOWICZ, 1994).

\section{Referências}

CANTARUTTI, R. B.; MARTINS, C. E.; CARVALHO, M. M.; FONSECA, D. M.; ARRUDA, M. L.; VILELA, H.; OLIVEIRA, F.T.T. Pastagens. In: RIBEIRO et al. (Eds.). Recomendações para o uso de corretivos e fertilizantes em Minas Gerais. 5a Aproximação Comissão de fertilidade do solo do Estado de Minas Gerais. Viçosa, MG, 1999. 359p.: Il.

GOMIDE, J. A. Exploração de pastagens em solos de baixa fertilidade (455-473). In: PEIXOTO, A .M. (Ed.). Pastagens: fundamentos da exploração racional. 2.ed. Piracicaba: FEALQ, 1994. 908 p.: Il. (FEALQ. Série atualizada em Zootecnia, 10).

LOBATO, E.; KORNELIUS, E.; SANZONOWICZ, C. Adubação Fosfatada em Pastagens (155-188). In: PEIXOTO, A. M. (Ed.). Pastagens: fundamentos da exploração racional. 2. ed. Piracicaba: FEALQ 1994. 908 p.: Il (FEALQ. Série atualizada em Zootecnia, $10)$.

NOVAES, R. F.; SMYTH, T. J.; NUNES, F. N. VIII - Fósforo (p. 471-550) In: NOVAIS et al., (Eds.). Fertilidade do Solo. Viçosa, MG. Sociedade Brasileira de Ciência do Solo. 2007. 1017 p.: Il.

WERNER, J. C. Calagem para plantas forrageiras. In: PEIXOTO et al. (Eds.). Pastagens: Fundamentos da exploração racional. 2. ed., Piracicaba: FEALQ 1994. p. 111-119; (FEALQ: Série atualização em zootecnia, 10). 908p. ;11. 


\section{NECESSIDADES DAS FORRAGEIRAS QUANTO AO FÓSFORO}

Jairo Rafael Machado Dias

A adubação fosfatada desempenha papel fundamental nos solos pobres, e as diferentes espécies de forrageiras se comportam de forma bastante variada em sua capacidade de aproveitamento de fósforo nas pastagens. Forrageiras consideradas como menos tolerantes ao alumínio e mais exigentes de fósforo são as pertencentes ao gênero botânico dos Pennisetum (capim elefante Cameron, paraíso, Taiwan etc.), dos Panicum (Mombaça, Tanzânia, Guiné, Áries, Colonião, Makuene etc.) e do gênero Hyparrhenia (capim provisório). As espécies Brachiaria bumidicola e Hyparrbenia rufa são capazes de utilizar baixas quantidades de fósforo, sendo mais eficientes do que outras plantas. Em ordem decrescente para tal situação, podem ser citadas: Pennisetum purpureum, Panicum maximum, Digitaria decumbens, Brachiaria decumbens e Melinis minutiflora (LOBATO, KORNELIUS, SANZONOWICZ, 1994). Cabe ressaltar que Andropogon gayanus comportou-se melhor em baixos níveis de fósforo, tanto na presença como na ausência de calcário, evidenciando sua maior capacidade de extrair fósforo, quando comparado com Setaria e Panicum. Para Panicum maximum cv Makueni foi verificada maior eficiência na utilização de fósforo na presença de calcário, dobrando a produção em relação ao tratamento sem calcário. As espécies de Panicum necessitam de solos férteis, com bons níveis de fósforo nativo ou mesmo aporte de fosfato via adubação (LOBATO, KORNELIUS, SANZONOWICZ, 1994).

As espécies de leguminosas nativas como Stylosanthes capitata, $S$. guianensis e Zornia são capazes de utilizar baixas quantidades de fósforo mais eficientemente do que outras plantas (LOBATO, KORNELIUS, SANZONOWICZ, 1994) como Glycini wightii (soja perene) (Portal Agronomia, 2009). Atualmente, o estilosantes Campo Grande, híbrido de 
Stylosanthes capitata e $S$ macrocephala têm grande destaque quanto à fixação biológica de nitrogênio e boa capacidade de consorciação com Brachiaria decumbens (EMBRAPA/Gado de Corte, 2002). Em geral, o teor de proteína bruta da forragem do consórcio é maior que o da gramínea em monocultura adubada com nitrogênio (VITOR et al., 2008).

Cabe ressaltar que, para o estabelecimento de Stylosanthes guianensis cv. Graham, S. scraba (Vog.) cv. Seca e Stylosanthes hamata (L.) Taub. Cv. Verano, o preparo mínimo de solo, juntamente com a aplicação de fósforo (64 kg ha ${ }^{-1}$ de $\mathrm{P}_{2} \mathrm{O}_{5}$ ), proporciona adequado estabelecimento das leguminosas no pasto (MESQUITA et al., 2002).

Frequentemente, a concentração de $\mathrm{P}$ disponível na solução do solo $\left(\sim 0,062 \mathrm{mg} . \mathrm{L}^{-1}\right)$ é várias ordens de magnitude menor do que aquela presente nos tecidos de plantas (155-620 $\left.\mathrm{mg} \mathrm{L}^{-1}\right)$. Seguem, na Tabela 1, os valores apresentados em forrageiras tropicais (MATTAR; FRADE JÚNIOR; OLIVEIRA 2013).

Tabela 1 - Concentrações de fósforo na matéria seca e seu nível crítico em algumas forrageiras tropicais

\begin{tabular}{|l|c|c|}
\hline \multirow{2}{*}{ Espécie } & \multicolumn{2}{|c|}{ \%P } \\
\cline { 2 - 3 } & Matéria Seca & Nível crítico \\
\hline Agropyron sp & 0,20 & \\
\hline Andropogon gayanus & 0,10 & \\
\hline Arachissp & 0,31 & $0,32^{2}$ \\
\hline Brachiaira decumbens & 0,08 & \\
\hline Brachiaria brizantha & 0,09 & $0,29^{2}$ \\
\hline Bracbiaria dictyoneura & 0,13 & \\
\hline Brachiaria humidicola & 0,08 & \\
\hline Bracbiaria mutica & 0,33 & \\
\hline Bromus inermis & 0,28 & $0,26-0,25^{1}$ \\
\hline Calopogonio sp & 0,12 & 0,16 \\
\hline Cenchrus ciliaris & & \\
\hline Centrosema macrocarpum & 0,16 & \\
\hline Centrosema pubescens & $0,18-0,23$ & \\
\hline Clitoria ternatea & 0,39 & \\
\hline Cratylia sp & 0,23 & \\
\hline Cynodon sp & $0,17-0,47$ & \\
\hline Cynodon dactylon & 0,20 & \\
\hline
\end{tabular}




\begin{tabular}{|l|c|c|}
\hline \multirow{2}{*}{\multicolumn{1}{|c|}{ Espécie }} & \multicolumn{2}{|c|}{ \%P } \\
\cline { 2 - 3 } & Matéria Seca & Nível crítico \\
\hline Dactylis glomerata & 0,37 & 0,22 \\
\hline Desmodium intortum & & 0,23 \\
\hline Desmodium ovalifolium & 0,10 & $0,16\left(0,29^{2}\right)$ \\
\hline Desmodium uncinatum & & \\
\hline Digitaria decumbens & $0,17-0,22$ & $0,16-0,53^{2}$ \\
\hline Dolichos lab-lab & 0,44 & \\
\hline Hyparrhenia rufa & $0,16-0,24$ & 0,17 \\
\hline Indigofera spp & 0,28 & 0,24 \\
\hline Lolium perene & 0,32 & 0,20 \\
\hline Lotononis bainesii & 0,22 & 0,24 \\
\hline Macroptilium atropurpureum & $0,16-0,24$ & $0,18-0,25^{1}$ \\
\hline Macroptilium lathyroides & & $0,23{ }^{2}$ \\
\hline Medicago sativa & 0,39 & \\
\hline Melinis minutiflora & $0,23-0,29$ & \\
\hline Panicum maximum cv coloniäo & $0,17-0,20$ & \\
\hline Panicum maximum cv Tanzânia & $0,10-0,30$ & \\
\hline Pennisetum purpureum cv Napier & $0,18-0,24$ & \\
\hline Poa pratenses & 0,26 & \\
\hline Pueraria phaseoloides & $0,22-0,29$ & \\
\hline Setaria sphacelata & $0,25-0,27$ & $0,22-0,20{ }^{1}$ \\
\hline Stylosanthes capitata & 0,12 & \\
\hline Stylosanthes guianansis & 0,16 & \\
\hline Stylosanthes humilis & 0,27 & \\
\hline Stylosanthes macrocephala & 0,10 & \\
\hline Teramnus uncinatus & 0,20 & \\
\hline Vigna luteola & & \\
\hline Zornia latifolia & 0,12 & \\
\hline Zornia sp & 0,25 & \\
\hline
\end{tabular}

1: crescimento inicial e rebrota, respectivamente; 2: ensaio feito em solução nutritiva; Fonte: Coligido de MALAVOLTA; LIEM; PRIMAVESI (1986, p. 43, 44, 48, 63); VEIGA; FALESI (1986, p. 267); FONTANELI et al., (2004); SOUSA et al., (2010); CORSI, (1994, p. 54); CORSI; SILVA (1994, p. 67); GOMIDE (1994, p. 467); PEIXOTO (1994, p. 625)

A variável “teores de nutrientes” em relação à matéria seca das plantas varia conforme a idade. Seu crescimento promove o fator de diluição dos nutrientes, demandando assim o seu nível crítico de fósforo (HAAG; DECHEN, 1994). Esses valores são compilados na Tabela 2, conforme as características do solo. 
Tabela 2 - Nível crítico de fósforo no solo para algumas forrageiras tropicais

\begin{tabular}{|c|c|c|c|}
\hline \multirow[t]{2}{*}{ Espécie } & \multicolumn{2}{|c|}{$\begin{array}{l}\text { Nível crítico no solo } \\
\left(\mathrm{mg} \mathrm{dm}{ }^{-3} \mathrm{de} \mathrm{P}\right)\end{array}$} & \multirow[t]{2}{*}{ Solo/característica } \\
\hline & Mehlich & Resima & \\
\hline Brachiaria decumbens $^{1}$ & 3,85 & 8,25 & \multirow{3}{*}{$\begin{array}{l}\text { Latossolo Vermelho } \\
\text { Amarelo, álico }\end{array}$} \\
\hline $\begin{array}{l}\text { Brachiaria brizantha } \\
\text { cv Marandu }{ }^{2}\end{array}$ & 10,8 & 21,8 & \\
\hline Panicum maximum ${ }^{1}$ & 5,75 & 11,25 & \\
\hline $\begin{array}{l}\text { Panicum maximum cv } \\
\text { Tanzânia }\end{array}$ & - & 38 & Argiloso, textura média \\
\hline $\begin{array}{l}\text { Brachiaria brizantha } \\
\text { cv Marandu }\end{array}$ & - & 9,0 & Latossolo Vermelho \\
\hline
\end{tabular}

1: Média de duas avaliações; 2: avaliação única;

Fonte: Coligido de GHERI et al., (2000); CORREA; HAAG (1993); CORAZZA et al., (2003)

Os níveis críticos para as espécies forrageiras tropicais são, provavelmente, mais baixos do que para as culturas anuais, variando para leguminosas tropicais de 3 a 7 ppm de P (LOBATO, KORNELIUS, SANZONOWICZ, 1994). Para as condições de solos tropicais e de baixa fertilidade natural, a estratégia de sobrevivência de planta está relacionada à eficiência na ciclagem de nutrientes. Essa ideia deve ser modelada tecnologicamente para os sistemas produtivos, a fim de torná-los sustentáveis (Tabela 3).

Tabela 3 - Quantidade de fósforo em componentes de um sistema ecológico de pastagens, suportando uma vaca com bezerro ao pé.

\begin{tabular}{lccc}
\hline & $\mathbf{K g ~ h a}^{-1}$ & \% (b) & \% (c) \\
\hline Total de P no ecossistema & 4162 & 100,0 & - \\
\hline Total de P no solo & 4106 & 98,7 & - \\
\hline Total de P em reciclagem & 261 & 6,3 & 100,0 \\
\hline Total de P nos componentes do ecossistema & & \\
\hline Animais & 7,3 & - & 2,8 \\
\hline Planta & 48,4 & - & 18,6 \\
\hline Resíduos & 39,3 & - & 15,1 \\
\hline Disponível no solo & 165,7 & - & 64,6 \\
\hline Indisponível no solo & 3901,0 & - & - \\
\hline
\end{tabular}




\begin{tabular}{lcccc}
\hline & & $\mathrm{Kg} \mathrm{ha}^{-1}$ & \% (b) & \% (c) \\
\hline Perdas & & & & \\
\hline & Lixiviação & 0,3 & - & 0,10 \\
\hline Erosão & 0,2 & - & 0,18 \\
\hline Animal & 3,8 & - & 1,30 \\
\hline Total de perdas & 4,3 & - & 1,58 \\
\hline
\end{tabular}

(b): \% de P em relação ao total no ecossistema; (c): \% de P em relação ao total passível de ser reciclado.

Fonte: Wilkinson, S. R. apud CORSI (1994, p. 58)

Apesar da complexidade relativa à espécie ou mistura a ser semeada, condições de solo, exigência das plantas, fertilizantes necessários, quantidade e formas de aplicação mais indicadas, frequência de adubações e produtividade esperada, observa-se que a tendência "normal" é a de se estabelecer as pastagens nos solos mais pobres, usando pequenas quantidades de insumos, criando-se uma expectativa em termos de boa produtividade e longevidade dessas pastagens (LOBATO; KORNELIUS; SANZONOWICZ, 1994). Em relação à Tabela 3, tem-se a impressão de que o ciclo do fósforo em pastagem é quase fechado, já que se perdem somente 4,3\% ao ano do elemento presente na reciclagem. Entretanto, a dinâmica envolve outra interpretação. As perdas são bem maiores quando se considera a sua fixação, imobilização por microrganismos e a distribuição ineficiente das excretas dos animais na área de pasto. Ou seja, quando a imobilização por microrganismos em resíduos de planta contenham menos do que $0,2 \%$ de $\mathrm{P}$ na matéria seca, ou quando a relação C:P é maior do que 200:1 (CORSI, 1994). Na literatura também consta que a relação $\mathrm{C}: \mathrm{P}$ menor que 100 leva à mineralização de P-orgânico; e C:P maior que 300, à imobilização de formas minerais de fósforo pelos microrganismos (NOVAIS, SMYTH, NUNES, 2007).

$\mathrm{A}$ imobilização de $\mathrm{P}$ pelos microrganismos em uma pastagem que suporta uma vaca com bezerro ao pé está ao redor de $16 \mathrm{~kg} \mathrm{ha}^{-1} \mathrm{ano}^{-1}$ de $\mathrm{P}(2 \mathrm{~kg}$ nas raízes mortas, $9 \mathrm{~kg}$ nas fezes e $5 \mathrm{~kg}$ na forragem perdida durante o pastejo). Se a pastagem for roçada sem ter sido usada pelo animal, a imobilização de $\mathrm{P}$ se eleva para cerca de $27 \mathrm{~kg} \mathrm{ha}^{-1} \mathrm{ano}^{-1} . \mathrm{Em}$ áreas destinadas à fenação ou ensilagem, a retirada de $\mathrm{P}$ é da ordem de 
$47 \mathrm{~kg} \mathrm{ha}^{-1}$ ano $^{-1}$ (CORSI, 1994). O retorno das excretas pode corresponder a 12\% (CORSI, 1994) ou mesmo variar de 10 a 47\% (FERREIRA et al., 2004), o que significa dizer que nesses locais pode ser considerado que a ciclagem de fósforo está em regime fechado, e o restante da área está submetido ao mesmo sistema, em que a forragem é cortada e transportada para outro local para ser utilizada pelo animal (CORSI, 1994). Em relação à eficiência desse ciclo fechado, deve ser considerado que os ácidos orgânicos das fezes competem com os sítios de adsorção de fósforo. Apesar de poderem ser rapidamente mineralizados pela microbiota do solo, a aplicação contínua de esterco mantém esse processo de bloqueio dos sítios de adsorção. A exsudação de ácidos orgânicos pelas raízes e o metabolismo de certos microrganismos também são importantes no processo (NOVAIS, SMYTH, NUNES, 2007).

Em termos de manejo para a aplicação de fósforo, deve ser considerado que sua aplicação localizada pode apresentar desvantagem por limitar o desenvolvimento radicular, tornando as plantas mais susceptíveis à seca. Isso tem interesse particular em regiões onde são frequentes as estiagens e é baixa a capacidade de retenção de água nos solos (LOBATO; KORNELIUS; SANZONOWICZ, 1994). Incorporações em diferentes profundidades, usando-se mangueira adaptada a subsolador, devem se estudadas. É importante ressaltar que, se o fósforo for reciclado eficientemente, as necessidades de adubação e manutenção seriam mínimas e poderiam ser feitas como menor frequência, diminuindo ainda mais o custo de produção (CORSI, 1994).

\section{Referências}

CORAZZA, E. J., BROSSARD, M., MURAOKAI, T., COELHO FILHO, M. A. Spatial variability of soil phosphorus of a low productivity Brachiaria brizantha pasture. Scientia Agricola, Piracicaba, v. 60, n. 3, p. 559-564, 2003.

CORSI, M. Exigências nutricionais de plantas forrageiras em pastagens (49-64). In: PEIXOTO, A. M. (Ed.). Pastagens: fundamentos da exploração racional. 2.ed. Piracicaba: FEALQ 1994. 908 p.: Il (FEALQ. Série atualizada em Zootecnia, 10).

CORSI, M.; SILVA, R. T. L. Fatores que afetam a composição mineral de plantas forrageiras (65-83). In: PEIXOTO, A. M. (Ed.). Pastagens: fundamentos da exploração racional. 2.ed. Piracicaba: FEALQ 1994. 908 p.: Il (FEALQ. Série atualizada em Zootecnia, 10). 
CORREA, L. A.; HAAG, H. P. Níveis críticos de fósforo para o estabelecimento de gramíneas forrageiras em Latossolo Vermelho Amarelo, álico: II. Experimento de campo. Scientia Agricola, Piracicaba, v. 50, n. 1, p. 109-116, maio 1993.

EMBRAPA/Gado de Corte. Estilosantes Campo Grande. Embrapa Gado de Corte divulga. n.38, out. 2000. Disponível em: http://www.cnpgc.embrapa.br/publicacoes/divulga/ GCD38.html. Acesso em 15 mar. 2011.

FERREIRA, E; ROCHA, G. C.; BRAZ, S. P.; SOARES, J. C.; ANDRADE, F. A. A. Modelos estatísticos para o estudo de distribuição de excretas de bovinos em pastagens tropicais e sua importância na sustentabilidade desse sistema. Livestock Research for Rural Development. v. 16, n. 9, 2004. Disponível em: http://www.lrrd.org/lrrd16/9/ferr16066. htm. Acesso em 16 de maio de 2014.

FONTANELI, R. S., SCHEFFER-BASSO, S. M., DÜRR, J. W., APPELT, J. V., BORTOLINI, F., HAUBERT, F. A. Predição da composição química de bermudas (Cynodon $s p p$.) pela espectroscopia de reflectância no infravermelho proximal. Revista Brasileira de Zootecnia, Viçosa, v. 33, n. 4, p. 838-842, ago. 2004.

GHERI, E. O., CRUZ, M. C. P., FERREIRA, M. E., PALMA, L. A. S. Nível crítico de fósforo no solo para Panicum maximum Jacq. cv. Tanzânia. Pesquisa Agropecuária Brasileira, Brasília, v. 35, n. 9, p. 1809-1816, set. 2000.

GOMIDE, J. A. Exploração de pastagens em solos de baixa fertilidade (455-473). In: PEIXOTO, A. M. (Ed.). Pastagens: fundamentos da exploração racional. 2.ed. Piracicaba: FEALQ 1994. 908 p.: Il (FEALQ. Série atualizada em Zootecnia, 10).

HAAG, H. P.; DECHEN, A. R. Deficiências minerais em plantas forrageiras (85-110). In: PEIXOTO, A. M.(Ed.). Pastagens: fundamentos da exploração racional. 2.ed. Piracicaba: FEALQ 1994. 908 p.: Il (FEALQ. Série atualizada em Zootecnia, 10).

LOBATO, E.; KORNELIUS, E.; SANZONOWICZ, C. Adubação Fosfatada em Pastagens (155-188). In: PEIXOTO, A. M. (Ed.). Pastagens: fundamentos da exploração racional. 2.ed. Piracicaba: FEALQ 1994. 908 p.: Il (FEALQ. Série atualizada em Zootecnia, 10).

MALAVOLTA, E.; LIEM, T H.; PRIMAVESI, A. C. P. A. Exigências nutricionais das plantas forrageiras. P. 31-76, In: MATTOS et al., (Eds.). Calagem e Adubação de Pastagens, POTAFOS, Piracicaba, São Paulo. 1986. p.31-76, 476p.: Il.

MATTAR, E. P. L.; FRADE JÚNIOR, E. F.; OLIVEIRA, E. (Eds). Cinza de ossos - fósforo e cálcio para a agricultura. Cruzeiro do Sul, AC: UFAC, 2013. 25 p.

MESQUITA, E. E. Efeitos de métodos de estabelecimento de braquiária e estilosantes e de doses de calcário, fósforo e gesso sobre alguns componentes nutricionais da forragem. Revista Brasileira de Zootecnia. Viçosa, v. 31, n. 6, p. 2186-2196, nov. 2002.

NOVAES, R. F.; SMYTH, T. J.; NUNES, F. N. VIII - Fósforo (p. 471-550) In: NOVAIS et al. (Eds.). Fertilidade do Solo. Viçosa, MG. Sociedade Brasileira de Ciência do Solo. 2007. 1017 p.: Il. 
PEIXOTO, A. M. A cana-de-açucar como recurso forrageiro (597-633). In: PEIXOTO, A.M. (Ed.). Pastagens: fundamentos da exploração racional. 2. ed. Piracicaba: FEALQ, 1994. 908 p.: Il (FEALQ. Série atualizada em Zootecnia, 10).

SOUSA, R. S., PIRES, A. J. V., CARVALHO, G. G. P., SILVA, F. F., MAGALHÃES, A. F., VELOSO, C. M. Composição química de capim-tanzânia adubado com nitrogênio e fósforo. Revista Brasileira de Zootecnia, Viçosa, v. 39, n. 6, p. 1200-1205, jun. 2010.

VEIGA, J. B.; FALESI, I. C. Recomendação e prática da adubação de pastagens cultivadas na Amazônia Brasileira, p. 257-282. In: MATTOS et al. (Eds.). Calagem e Adubação de Pastagens, POTAFOS, Piracicaba, São Paulo. 1986. 476p.: Il.

VITOR, C. M. T., FONSECA, D. M., MOREIRA, L. M., FAGUNDES, J. L., NASCIMENTO JÚNIOR, D., RIBEIRO JÚNIOR, J. I., PEREIRA, A. L. Rendimento e composição química do capim-braquiária introduzido em pastagem degradada de capim-gordura. Revista Brasileira de Zootecnia, Viçosa, v. 37, n. 12, p. 2107-2114, 2008. 


\section{FARINHA DE OSSOS CALCINADA EM FORRAGEIRAS}

Alisson Vinicius Lorencetti Ferreira

Elvino Ferreira

Jucilene Cavali

Fosfatos de baixa reatividade podem ser empregados em sistemas perenes - ou pelo menos de longa duração - em que os requerimentos externos de fósforo pela forrageira após seu estabelecimento são relativamente baixos. Os níveis de acidez do solo favorecem a solubilização desses fosfatos e, em especial, aquelas espécies com maior potencial de acidificação da rizosfera favorecem ainda mais seu aproveitamento. Pode ser considerado que, em pastagens de baixo e médio nível tecnológico, recomenda-se a aplicação de 250 a $500 \mathrm{~kg} \mathrm{ha}^{-1}$ de fosfato de baixa reatividade incorporado aos primeiros $15 \mathrm{~cm}$ (CANTARUTTI et al., 1999). Em relação à baixa e lenta liberação de fósforo, a utilização de fosfatos naturais tem ocorrido mais como fosfatagem corretiva, com a aplicação de 1 ou mais toneladas por hectare, sobre toda a área com incorporação com arado ou grade (NOVAIS, SMYTH, NUNES, 2007). Em relação à calagem, as dosagem não devem ser maiores que 3 toneladas por hectare (WERNER, 1994). Isso posto, o emprego da farinha de ossos calcinada poderia suprir ambos os requisitos tecnológicos em relação ao emprego do calcário e da adubação fosfatada, no tocante ao fornecimento desses nutrientes, para condições de nível tecnológico médio, ou mesmo quando forrageiras mais adaptadas a níveis de solo com $\mathrm{pH}$ mais ácidos estivessem em uso. Na Tabela 1, comparando-se o calcário calcítico com a farinha de ossos calcinada, tem-se quantidades próximas de óxido de cálcio e de magnésio aportadas ao solo, mas com a vantagem da presença de fosfato, quando se considera a farinha de ossos. A questão de solubilidade deve ser estudada em relação ao tratamento ácido desse material. 
Tabela 1 - Quantidades em kg por hectares de óxidos de cálcio, de magnésio e de fosfato, quanto a diferentes quantidades de calcário e de farinha de ossos calcinada aportadas ao solo.

\begin{tabular}{|c|c|c|c|c|c|c|}
\hline \multirow[t]{2}{*}{ Fonte } & \multicolumn{6}{|c|}{$\begin{array}{l}\text { Quantidade aportada ao solo }(\mathrm{kg}) \text { com aplicação de diferentes } \\
\text { fontes (toneladas por hectare) }\end{array}$} \\
\hline & Concentração & 0,25 & 0,5 & 1,0 & 2,0 & 3,0 \\
\hline \multirow{2}{*}{$\begin{array}{l}\text { Calcário } \\
\text { calcítico }\end{array}$} & $\begin{array}{c}\mathrm{CaO} \\
(40-45 \%)\end{array}$ & 106,2 & 212,5 & 425 & 850 & 1275 \\
\hline & $\begin{array}{c}\mathrm{MgO} \\
(1-5 \%)\end{array}$ & 7,5 & 15 & 30 & 60 & 90 \\
\hline \multirow{2}{*}{$\begin{array}{l}\text { Calcário } \\
\text { magnesiano }\end{array}$} & $\begin{array}{c}\mathrm{CaO} \\
(31-40 \%)\end{array}$ & 88,7 & 177,5 & 355 & 710 & 1065 \\
\hline & $\begin{array}{c}\mathrm{MgO} \\
(6-12 \%) \\
\end{array}$ & 22,5 & 45 & 90 & 180 & 270 \\
\hline \multirow{2}{*}{$\begin{array}{l}\text { Calcário } \\
\text { dolomítico }\end{array}$} & $\begin{array}{c}\mathrm{CaO} \\
(25-30 \%)\end{array}$ & 68,7 & 137,5 & 270 & 550 & 810 \\
\hline & $\begin{array}{c}\mathrm{MgO} \\
(13-20 \%)\end{array}$ & 41,2 & 82,5 & 165 & 330 & 495 \\
\hline \multirow{3}{*}{$\begin{array}{l}\text { Farinha } \\
\text { de ossos } \\
\text { calcinada }\end{array}$} & $\begin{array}{c}\mathrm{CaO} \\
(39-48 \%)\end{array}$ & 108,7 & 217,5 & 435 & 870 & 1305 \\
\hline & $\begin{array}{c}\mathrm{MgO} \\
(0,82-0,97 \%) \\
\end{array}$ & 2,2 & 4,4 & 8,95 & 17,9 & 26,8 \\
\hline & $\begin{array}{l}\mathrm{P}_{2} \mathrm{O}_{5} \text { total } \\
(30,6-38,8)\end{array}$ & 86,7 & 173,5 & 347 & 694 & 1041 \\
\hline
\end{tabular}

Fonte: SIQUEIRA (1986), p. 85; FERREIRA; BALBINO (2014)

Se consideradas pastagens de baixo e médio nível tecnológico, recomenda-se a aplicação de 250 a $500 \mathrm{~kg} \mathrm{ha}^{-1}$ de fosfato de baixa reatividade, incorporados aos primeiros $15 \mathrm{~cm}$ (CANTARUTTI et al., 1999), com o emprego da farinha de ossos calcinada, o que promoveria certa correção do solo juntamente com aporte de fosfato, sendo portanto empregado apenas um manejo da aplicação de produto para a construção de sua fertilidade. $\mathrm{O}$ uso da farinha de ossos calcinada $(39-48 \% \mathrm{CaO} ; 0,82-0,97 \% \mathrm{MgO}$ e 30,6-38,8\% $\mathrm{P}_{2} \mathrm{O}_{5}$ total; FERREIRA; BALBINO, 2014) representaria uma vantagem adicional em relação à adição de fosfato, se fosse comparado ao emprego do calcário calcítico (40-45\% $\mathrm{CaO}$ e 1-5\% MgO; SIQUEIRA, 
1986, p.85). Ambientes ácidos para promoção da solubilização de fosfato bem como o tempo necessário para que os efeitos corretivos, quanto ao $\mathrm{pH}$ do solo, deveriam ser estudados para o desenvolvimento de tal tecnologia. Pelets com camadas de solubilidade diferenciada poderiam ser testados, uma vez que, com o passar do tempo, os níveis de acidez do solo favorecem a solubilização desses fosfatos e, em especial, aquelas espécies com maior potencial de acidificação da rizosfera favorecem ainda mais seu aproveitamento (CANTARUTTI et al., 1999). Tais condições podem aperfeiçoar o aproveitamento de nutrientes para as plantas e, com isso, a produção de forragens (Tabela 2).

Tabela 2 - Idade (dias), produção de matéria seca (MS) e extração de cálcio, magnésio e fósforo em algumas forrageiras tropicais

\begin{tabular}{lccccccccc}
\hline \multirow{2}{*}{ Espécie } & \multirow{2}{*}{$\begin{array}{c}\text { Corte } \\
\text { (dias) }\end{array}$} & \multirow{2}{*}{$\begin{array}{c}\text { MS } \\
\left(\mathrm{t} \mathrm{ha}^{-1}\right)\end{array}$} & \multicolumn{5}{c}{ Quantidade de nutrientes extraídos por: } \\
\cline { 4 - 9 } & & $\mathrm{Ca}$ & $\mathrm{Mg}$ & $\mathrm{P}$ & $\mathrm{Ca}$ & $\mathrm{Mg}$ & $\mathrm{P}$ \\
\hline $\begin{array}{l}\text { Andropogon } \\
\text { gayanus }\end{array}$ & 80 & 50,0 & 139,2 & 83,0 & 55,8 & 2,6 & 1,6 & 1,1 \\
\hline $\begin{array}{l}\text { Centrosema } \\
\text { pubescens }\end{array}$ & 130 & 5,8 & 5,4 & 1,2 & 1,6 & 0,9 & 0,2 & 0,2 \\
\hline $\begin{array}{l}\text { Cynodon } \\
\text { Coastal } \\
\text { bermuda }\end{array}$ & - & 25 & & & & & & 0,063 \\
\hline $\begin{array}{l}\text { Dactylis } \\
\text { glomerata }\end{array}$ & - & 10 & & & & & & 0,028 \\
\hline $\begin{array}{l}\text { Digitaria } \\
\text { decumbens } \mathrm{cv} \\
\text { Pangola }\end{array}$ & - & 24 & & & & 0,109 & 0,067 & 0,047 \\
\hline $\begin{array}{l}\text { Glycine } \\
\text { wightii }\end{array}$ & 140 & 4,8 & 48,5 & 11,6 & 10,2 & 10,1 & 2,4 & 2,1 \\
\hline $\begin{array}{l}\text { Leucaena } \\
\text { leucocephala } \\
\text { cv. Peru }\end{array}$ & 360 & 46,0 & 302,0 & 36,0 & 28,0 & 6,5 & 0,7 & 0,6 \\
\hline $\begin{array}{l}\text { Macroptilium } \\
\text { atropurpu- } \\
\text { reum }\end{array}$ & 140 & 1,4 & 25,3 & 4,9 & 3,1 & 18,0 & 3,5 & 2,1 \\
\hline $\begin{array}{l}\text { Melinis } \\
\text { minutiflora } \\
\text { (Gordura) }\end{array}$ & - & 13 & & & & 0,056 & 0,044 & 0,032 \\
\hline
\end{tabular}




\begin{tabular}{|c|c|c|c|c|c|c|c|c|}
\hline \multirow{3}{*}{ Espécie } & \multirow{3}{*}{$\begin{array}{l}\text { Corte } \\
\text { (dias) }\end{array}$} & \multirow{3}{*}{$\begin{array}{c}\text { MS } \\
\left(\mathrm{tha}^{-1}\right)\end{array}$} & \multicolumn{6}{|c|}{ Quantidade de nutrientes extraídos por: } \\
\hline & & & \multicolumn{3}{|c|}{ hectare } & \multicolumn{3}{|c|}{ Em toneladas de MS } \\
\hline & & & $\mathrm{Ca}$ & $\mathrm{Mg}$ & $\mathbf{P}$ & $\mathrm{Ca}$ & $\mathrm{Mg}$ & $\mathbf{P}$ \\
\hline $\begin{array}{l}\text { Panicum } \\
\text { maximum cv } \\
\text { Makueni }\end{array}$ & 130 & 1,3 & 7,0 & 6,4 & 1,3 & 5,3 & 4,9 & 1,0 \\
\hline $\begin{array}{l}\text { Panicum } \\
\text { maximum cv. } \\
\text { Colonião }\end{array}$ & - & 23 & & & & 0,149 & 0,099 & 0,044 \\
\hline $\begin{array}{l}\text { Pennisetum } \\
\text { purpureum } \\
\text { cv. Napier }\end{array}$ & - & 25 & & & & 0,096 & 0,063 & 0,064 \\
\hline
\end{tabular}

Fonte: Modificado de LOBATO, KORNELIUS, SANZONOWICZ (1994), p. 175, citando outros autores; MALAVOLTA, LIEM, PRIMAVESI (1986), p. 46.

Solos do Cerrado, por exemplo, caracterizados pela deficiência de fósforo, cálcio, magnésio e elevados teores de alumínio e manganês, apresentam baixa atividade de bactérias nitrificantes, sendo o amônio a forma de nitrogênio predominante nesse sistema. Contudo, a nitrificação pode aumentar com a correção da acidez, e os microrganismos heterotróficos envolvidos na mineralização da matéria orgânica também podem apresentar ação nitrificante. Admite-se que o maior influxo de nitrato resulta em aumento do $\mathrm{pH}$ na rizosfera (SOUZA, 2003). Plantas que absorvem amônio ou utilizam $\mathrm{N}_{2}$ simbiótico reduzem o $\mathrm{pH}$ rizosférico, acarretanto diferenças de 1-2 unidades de $\mathrm{pH}$ entre a rizosfera e o solo (ARAUJO; MACHADO, 2006; NOVAIS, SMYTH, NUNES, 2007), e podem se estender a uma distância de 1 a $4 \mathrm{~mm}$ da superfície radicular (GAHOONIA et al., 1992 apud ARAUJO; MACHADO, 2006). Por meio da variação de $\mathrm{pH}$ na rizosfera de gramíneas, observou-se o efeito do alumínio no aumento do influxo de amônio e exsudação de $\mathrm{H}^{+}$ pelo sistema radicular, como forma de manutenção do potencial elétrico da membrana plasmática (SOUZA, 2003). O autor ainda considera que plantas com mecanismos fisiológicos de tolerância ao alumínio apresentem maior capacidade de absorção de amônio.

E interessante considerar que o fósforo é um elemento pouco móvel no solo. Isso equivale a dizer que ele permanece no local de aplicação. 
Russel (1973 apud CORSI, 1994) cita que o fósforo no solo foi deslocado somente $6,5 \mathrm{~cm}$ do local de aplicação, após 5 anos. Estima-se que sua difusão no solo seja de $10^{-11} \mathrm{~cm}^{2} \mathrm{~s}^{-1}$ (NOVAIS, SMYTH, NUNES, 2007). Perdas mínimas ocorrem por lixiviação, quando em formas orgânicas, e por erosão das camadas superficiais do solo (NOVAIS, SMYTH, NUNES, 2007; SANTOS et al., 2010). Seu manejo em cápsulas (pelets) representaria um compartimento "protetor" aos efeitos de adsorção do solo, e possivelmente a presença de cálcio promoveria em seu entorno um $\mathrm{pH}$ favorável ao estabelecimento inicial de raízes. Como o passar do tempo e com a colonização radicular, o aproveitamento do fósforo de menor solubilidade poderia se dar pela secreção de fosfatases ácidas na rizosfera, sendo tal mecanismo desencadeado pelo requerimento de fósforo na planta (ARAUJO; MACHADO, 2006).

Para as fertilizações com adubos fosfatados, normalmente conta-se tanto com fontes de elevada solubilidade (Superfosfato triplo, superfosfato simples, fosfato monoamônico, entre outros) quanto de solubilidade reduzida (Fosfatos naturais, fosfatos de Araxá, escoria de Thomas, farinha de ossos calcinada, dentre outros), mas as interações entre os diferentes tipos de solo e as diversas cultivares de plantas carecem de estudos pontuais. Tem-se que quanto mais reativo for o fosfato, mais prejudicial será o efeito do tempo de contato com o solo sobre sua disponibilidade de fósforo para as plantas (NOVAIS, SMYTH, NUNES, 2007).

Em relação às fontes de baixa solubilidade, a farinha de ossos calcinada como também a farinha de carne e ossos vêm sendo estudadas pelo Grupo de Estudos em Produção Animal e Aproveitamento de Resíduos (GEPAAR). Como resultados gerados nas ações de pesquisa do referido grupo, pode-se citar que: Para o capim Tifton foi observado que a farinha de carne e ossos gerou respostas com eficiência variando entre 65 a 93\%, em relação à produção de matéria seca da parte aérea de capim Tifton (Cynodon dactilon L.), quando comparada à adubação com superfosfato simples (SIMÕES, 2011).

A condição dose resposta pode não ser evidenciada de forma imediata em decorrência da solubilidade das fontes testadas. As condições climáticas 
também são fatores decisivos, como se pode observar com o primeiro corte no capim Tifton, que não houve resposta significativa para nenhum dos tratamentos, farinha de carne e ossos e super simples (Figura 1). A variabilidade na resposta de fontes de baixa solubilidade pode não permitir ajuste por regressão (Figura 1); e associações microbiológicas, com micorrizas, podem representar uma maior habilidade das raízes das plantas em aproveitar as formas de fosfato, quando na exploração do volume de solo.

Lana et al., (2004 apud SIMÕES et al. 2012), trabalhando com essas mesmas fontes de $\mathrm{P}$ (farinha do carne e osso e super simples) para a alface, relataram maior produtividade para as fontes de maior solubilidade e ainda comentaram que o uso da farinha de carne e ossos necessita de tempo maior que 25 dias de antecedência ao plantio, a fim de promover uma maior mineralização dos nutrientes dessa fonte. Tal relado corrobora com este estudo, uma vez que a aplicação da farinha de carne e ossos foi adicionada ao solo como tratamento apenas 10 dias antes do plantio das mudas.

Figura 1 - Ajuste de regressões para os tratamentos de doses de Fósforo (100, 200 e $300 \mathrm{~kg} \mathrm{ha}^{-1} \mathrm{de}_{2} \mathrm{O}_{5}$ ) na forma de superfosfato simples e farinha de carne e ossos para o capim Tifton (Cynodon dactilon): (a) Primeiro corte - 30 DAP, (b) Segundo corte - 60 DAP, (c) Terceiro corte - 90 DAP e (d) Quarto corte - 120 DAP

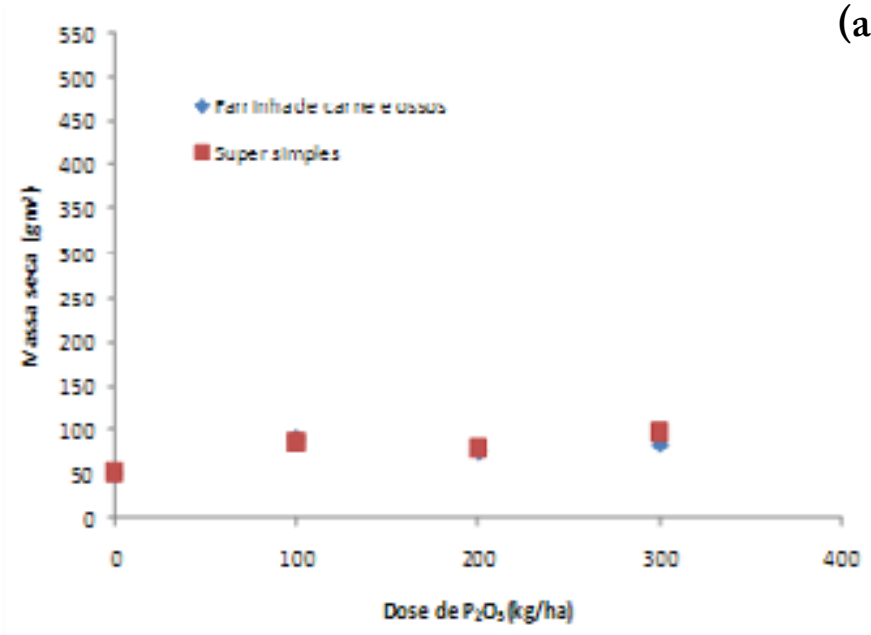

(a) 
(b)

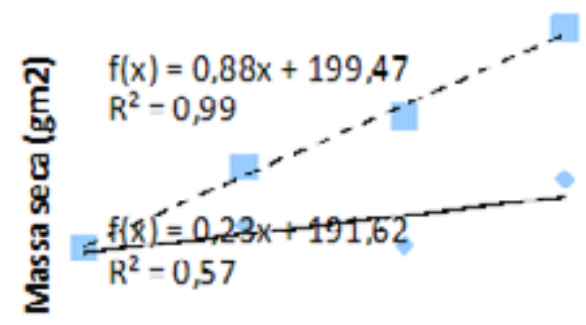

Dose de P205(kg/ha)
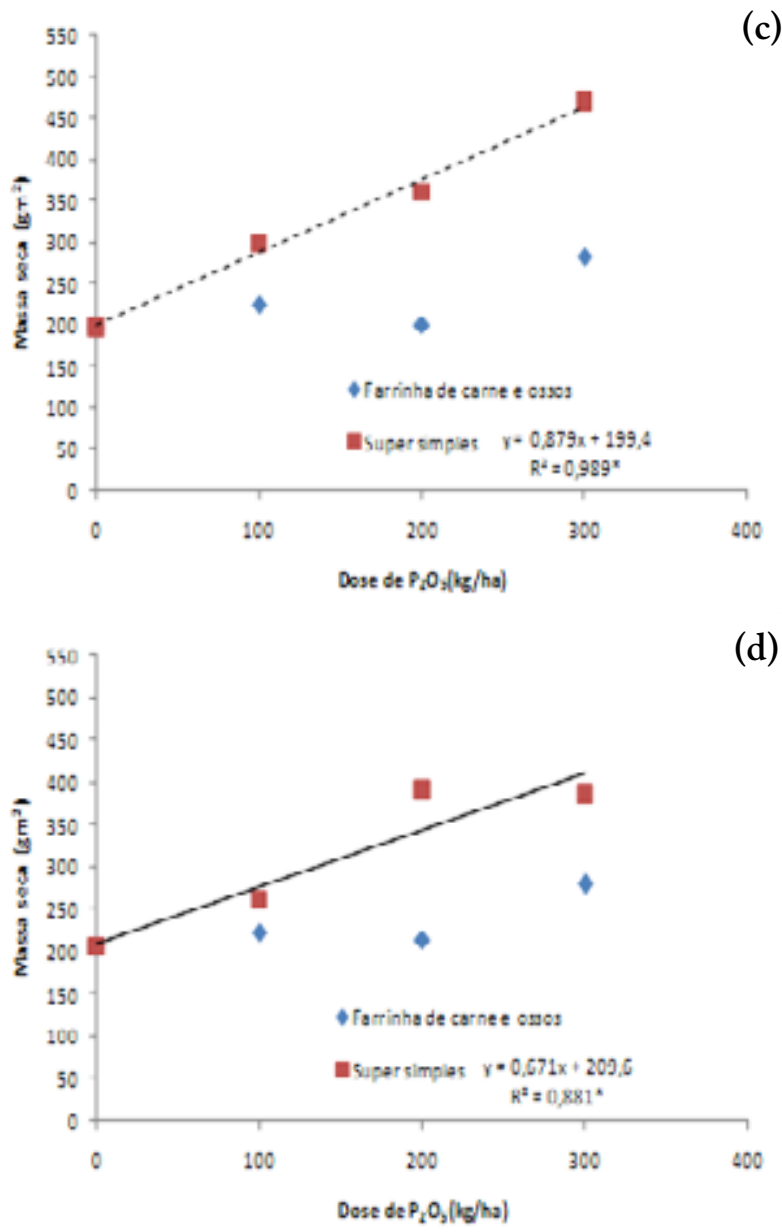

Fonte: SIMOES et al., 2012. 
$\mathrm{Na}$ avaliação da eficiência em produção de matéria seca entre os diferentes tratamentos, podem ser observados resultados importantes em relação às fontes de Fósforo usadas. Em relação ao tratamento testemunha, houve uma superioridade em produção de matéria seca da parte aérea do Tifton em 437\% quando $300 \mathrm{~kg} \mathrm{ha}^{-1}$ de $\mathrm{P}_{2} \mathrm{O}_{5}$ na forma de farinha de carne e ossos foram usados, ou até mesmo $562 \%$, relativo ao tratamento com 300 $\mathrm{kg} \mathrm{ha} \mathrm{p}^{-1}$ de $\mathrm{P}_{2} \mathrm{O}_{5}$ na forma de superfosfato simples (Tabela 3).

$\mathrm{Na}$ comparação entre os tratamentos com as diferentes fontes de Fósforo, pode ser observado que as diferenças em eficiência foram menores no nível de $100 \mathrm{~kg} \mathrm{ha}^{-1}$ de $\mathrm{P}_{2} \mathrm{O}_{5}(93 \%)$ da farinha de carne e ossos, em relação ao superfosfato simples, ficando os demais em níveis menores, porém satis-

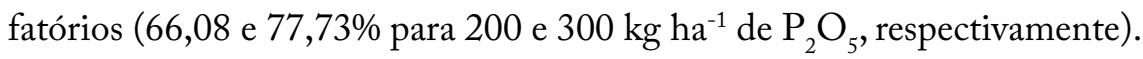
Em relação à fonte estudada, Venegas (2009 apud SIMOES et al. 2012), avaliando os efeitos de diferentes doses de farinha de carne e ossos na produção de milho, observou que tal adubação proporcionou rendimentos tão eficientes quanto à adubação convencional para a cultura.

Tabela 3 - Relação entre as produções médias de matéria seca $\left(\mathrm{g} \mathrm{m}^{-2}\right)$ dos tratamentos submetidos a duas fontes de fosfato (Super simples - SS e Farinha de Carne Ossos - FCO) da parte aérea do capim Tifton (Cynodon dactilon)

\begin{tabular}{ccc}
\hline Tratamentos & Relação numérica & Resultado \\
\hline $\mathrm{N} / \mathrm{t}$ & $=708,51 / 255,38$ & $=2,77$ \\
\hline $\mathrm{SS} 100 / \mathrm{t}$ & $=988,94 / 255,38$ & $=3,87$ \\
\hline $\mathrm{SS} 200 / \mathrm{t}$ & $=1321,28 / 255,38$ & $=5,17$ \\
\hline $\mathrm{SS} 300 / \mathrm{t}$ & $=1436,35 / 255,38$ & $=5,62$ \\
\hline $\mathrm{FCO} 100 / \mathrm{t}$ & $=929,40 / 255,38$ & $=3,63$ \\
\hline $\mathrm{FCO} 200 / \mathrm{t}$ & $=867,20 / 255,38$ & $=3,39$ \\
\hline $\mathrm{FCO} 300 / \mathrm{t}$ & $=1116,56 / 255,38$ & $=4,37$ \\
\hline------------------------------------------------------------------------- \\
\hline FCO100/SS100 & $=929,40 / 988,94$ & $=0,93$ \\
\hline FCO200/SS200 & $=867,20 / 1321,28$ & $=0,65$ \\
\hline FCO300/SS300 & $=1116,56 / 1436,35$ & $=0,77$
\end{tabular}

Testemunha $\left(\mathrm{t}\right.$ ), Nitrogênio (cobertura de $20 \mathrm{~kg} \mathrm{ha}^{-1} \mathrm{de} \mathrm{N}$ - uréia), superfosfato Simples (SS) e farinha de carne e ossos (FCO) nas doses de 100, 200 e $300 \mathrm{~kg} \mathrm{ha}^{-1}$ de $\mathrm{P}_{2} \mathrm{O}_{5}$ Fonte: SIMOES et al., (2012). 
Aos 150 dias após o plantio (DAP), procedeu-se uma coleta destrutiva, a fim de se verificar possível diferença na relação parte aérea e raízes das plantas de Tifton com os diferentes tratamentos. Pode ser verificado que, naquele momento, os tratamentos testemunha, SS100, SS200, SS300 e FCO100, apresentaram uma maior proporção de parte aérea em relação às suas raízes. O maior valor obtido ocorreu no SS100 (27\% maior PA), sendo bem próximo aos tratamentos SS200 (25\%) e FCO (23\%). Tal situação foi invertida (raízes apresentando maior proporção) nos tratamentos com “apenas N”, FCO 200 e FCO 300, apesar de as diferenças não serem tão grandes (Tabela 4).

Pode ser considerado que um bom desenvolvimento radicular gera a oportunidade de um maior volume de solo explorado pelas raízes. Também é interessante ser observado que os tratamentos que apresentaram maior valor na relação R:PA foram aqueles que, de maneira geral, sempre produziram maiores quantidades de MS (g.m $\mathrm{m}^{-2}$ ), possivelmente porque essas maiores produções foram geradas em função da fonte de fósforo com maior solubilidade. No entanto, é importante ser lembrado que as raízes das plantas representam um compartimento de elevada dinâmica, e os indicativos de aproveitamento das fontes de $\mathrm{P}$ usadas neste experimento devem ser embasados com as relações de $\mathrm{P}$ no tecido do vegetal (enviadas para Embrapa Acre e aguardando resposta).

Tabela 4 - Relação de produção de matéria seca $\left(\mathrm{g} \mathrm{m}^{-2}\right)$ da parte aérea e das raízes do capim Tifton (Cynodon dactilon L) submetido a duas fontes de fosfato (Super Simples - SS e Farinha de Carne e Ossos - FCO), cortado a cada 30 dias com cobertura de $20 \mathrm{~kg} \mathrm{ha}^{-1}$ de N (ureia) por corte. Rolim de Moura, RO (2011).

\begin{tabular}{lccc}
\hline \multirow{2}{*}{ Tratamentos } & \multicolumn{2}{c}{ Matéria Seca $(\mathrm{g})$} & Relação \\
\cline { 2 - 3 } & Raízes $(\mathrm{R})$ & Parte Aérea $(\mathrm{PA})$ & R: PA \\
\hline Testemunha & $14,06 \pm 1,73$ & $15,5 \pm 0,77$ & 0,90 \\
\hline Apenas N & $15,13 \pm 1,12$ & $11,46 \pm 3,77$ & 1,32 \\
\hline SS 100 & $17,75 \pm 0,85$ & $22,56 \pm 2,12$ & 0,78 \\
\hline SS 200 & $17,74 \pm 0,76$ & $22,18 \pm 0,63$ & 0,79 \\
\hline SS 300 & $24,75 \pm 1,52$ & $29,36 \pm 1,90$ & 0,84 \\
\hline FCO 100 & $19,13 \pm 3,27$ & $23,54 \pm 1,08$ & 0,81 \\
\hline FCO 200 & $12,76 \pm 0,36$ & $11,77 \pm 0,57$ & 1,08 \\
\hline FCO 300 & $22,71 \pm 3,04$ & $19,75 \pm 0,84$ & 1,14 \\
\hline
\end{tabular}

Fonte: Simões et al., (2012). 
O uso de farinha de carne e ossos avaliada quanto à produção em matéria seca da parte aérea de Brachiaria brizantha cv. Marandu resultou em produções semelhantes após três cortes, com intervalo de 30 dias ao tratamento com superfosfato triplo (NICOLAU, 2011). Já com capim mais exigente, como é o caso do tifton, o emprego de farinha de ossos calcinada em tratamentos com níveis de $\mathrm{P}$ em dose de $100 \mathrm{~kg} \mathrm{ha}^{-1} \mathrm{de}_{2} \mathrm{O}_{5}$ aos 30 dias, as plantas apresentaram sintomatologia pertinente com a deficiência de fosfatos (BALBINO, 2011).

Também pode ser relatado que o uso de farinha de ossos calcinada produziu efeitos satisfatórios quanto à produção de matéria seca em capim elefante (Pennisetum purpureum Schum.) (ARVELINO, 2011). Em relação aos dados de produção de matéria seca $\left(\mathrm{g} \cdot \mathrm{m}^{-2}\right)$, os dados observados neste trabalho (Tabela 6) estão com valores menores em relação aos observados na literatura. Barbosa et al. (1995 apud ARVELINO, 2011) relatam, para o capim elefante Vruckwona, uma produção equivalente em 211,20 g.m ${ }^{-2}$ de MS. Contudo, é importante relatar que a variedade estudada não foi totalmente classificada em relação aos seus caracteres botânicos morfológicos, e as mudas foram originadas de capineira plantada com sementes de capim elefante Paraíso. Essa variedade permite seu intercruzamento e, com isso, a perda das características agronômicas, em sucessivos plantios.

Tabela 6 - Produção de matéria seca $\left(\mathrm{g} \cdot \mathrm{m}^{-2}\right)$ da parte aérea do capim elefante (Pennisetum purpureum. Schum) submetido a duas fontes de fosfato (Super Simples - SS e Farinha de ossos calcinada - FOC), cortado a cada 30 dias com cobertura de 30 kg.ha ${ }^{-1}$ de $\mathrm{N}$ (ureia) por corte

\begin{tabular}{lcccc}
\hline \multirow{2}{*}{ Tratamentos } & \multicolumn{3}{c}{ Matéria Seca $\left(\mathbf{g} \cdot \mathbf{m}^{-2}\right)$} & \multirow{2}{*}{ Média } \\
\cline { 2 - 4 } & I & II & III & \\
\hline Testemunha & 468.16 & 436.73 & 451.42 & $452,11 \mathrm{~d}$ \\
\hline FOC 100 & 771.83 & 559.18 & 679.18 & $670,07 \mathrm{ab}$ \\
\hline FOC 200 & 835.51 & 629.79 & 764.48 & $743,26 \mathrm{a}$ \\
\hline FOC 300 & 781.22 & 674.28 & 737.14 & $730,88 \mathrm{a}$ \\
\hline SS 100 & 603.67 & 502.85 & 560.81 & $555,78 \mathrm{c}$ \\
\hline SS 200 & 608.97 & 538.77 & 550.61 & $566,12 \mathrm{c}$ \\
\hline SS 300 & 639.59 & 604.48 & 605.30 & $616,46 \mathrm{bc}$ \\
\hline \multicolumn{5}{c}{ CV $=14,88 \%$} \\
\hline
\end{tabular}

$\overline{\text { Não foi aplicado o teste de comparação de médias porque o } \mathrm{F} \text { e da interação tratamento e }}$ épocas não foram significativos. Para as médias dentro dos tratamentos, são significantes pelo teste de Tukey (<0.05). Tratamentos: $\mathrm{P}_{2} \mathrm{O}_{5}\left(100,200\right.$ e 300 kg.ha $\left.{ }^{-1}\right)$. Fonte: Arvelino (2011) 
Em relação à comparação entre os tratamentos fosfatados com o tratamento testemunha, pode ser observado que aqueles foram superiores, em média, em 27,7\%. Quando se comparam os dados médios dos tratamentos de farinha de ossos calcinada aos de superfosfato simples, as diferenças encontradas são de 23\%. Tal resultado é indicativo de que essas fontes resultam em efeitos próximos e importantes para o produtor quando o preço dos adubos fosfatados estão muito discrepantes. Os resultados das comparações individuais se encontram na Tabela 7.

Tabela 7 - Relação entre as produções médias de matéria seca $\left(\mathrm{g} \cdot \mathrm{m}^{-2}\right)$ da parte aérea do capim-elefante (Pennisetum purpureum Schum) em função das fontes de fosfato (Super Simples - SS e Farinha de ossos calcinada - FOC)

\begin{tabular}{ccc}
\hline Tratamentos & Relação numérica & Resultado \\
\hline $\mathrm{SS} 100 / \mathrm{t}$ & $=555,78 / 452,11$ & $=1,22$ \\
\hline $\mathrm{SS} 200 / \mathrm{t}$ & $=566,12 / 452,11$ & $=1,25$ \\
\hline $\mathrm{SS} 300 / \mathrm{t}$ & $=616,46 / 452,11$ & $=1,36$ \\
\hline $\mathrm{FOCal} 100 / \mathrm{t}$ & $=555,78 / 452,11$ & $=1,22$ \\
\hline FOCal 200/t & $=566,12 / 452,11$ & $=1,25$ \\
\hline FOCal 300/t & $=616,46 / 452,11$ & $=1,36$ \\
\hline$--------------------------------------------------1,20$ \\
\hline FOCal 100/SS100 & $=670,07 / 555,78$ & $=1,31$ \\
\hline FOCal 200/SS200 & $=743,26 / 566,12$ & $=1,18$ \\
\hline FOCal 300/SS300 & $=730,88 / 616,46$ &
\end{tabular}

Testemunha ( $\mathrm{t}$ ), superfosfato triplo (SS) e farinha de ossos calcinada (FOC) nas doses de 100, 200 e 300 kg.ha ${ }^{-1}$ de $\mathrm{P}_{2} \mathrm{O}_{5}$.

Fonte: ARVELINO (2011).

Inicialmente, os cortes foram previstos para ocorrerem com intervalos de 30 dias, contudo, em função de imprevistos de caráter biológico, houve a necessidade de ser adiado o segundo corte (atrasando-o em 15 dias) e de os tratamentos sofrerem um corte de uniformização. Também é importante relatar que o experimento foi conduzido em baldes de 10 $\mathrm{kg}$, o que pode representar um impedimento para o desenvolvimento das raízes e consequente produção de MS da parte aérea. Também no decorrer do período experimental, observou-se a ocorrência de manchas foliares 
condizentes com a infecção fúngica por Bipolaris maydis. A suscetibilidade do capim-elefante a $B$. maydis pode comprometer seu estabelecimento no Cerrado e em outras regiões tropicais, pois o patógeno pode reduzir sua persistência e capacidade de produção de massa (CHARCAR et al., 2008 apud ARVELINO, 2011).

Já para a produção da parte aérea de estilosantes Campo Grande, inicialmente o emprego da farinha de ossos calcinada no solo foi comparada aos efeitos produzidos com calcário e com a testemunha. Sua presença após 60 dias de incubação promoveu elevação no $\mathrm{pH}$ (de 4,8 para 6,7) do solo (FERRO, CUNHA \& FERREIRA, 2013). Nesse estudo, foram usados baldes de $15 \mathrm{~kg}$ cultivados com estilosantes, aos quais foram aplicadas quantidades equivalentes a $500 \mathrm{~kg} \mathrm{ha}^{-1} \mathrm{P}_{2} \mathrm{O}_{5}$, submetidos a três cortes com intervalos de 30 dias, com os quais eram aplicados $80 \mathrm{~kg} \mathrm{ha}^{-1}$ de cloreto de potássio. Em relação às diferentes granulometrias estudadas para FOC, esse material foi passado em peneiras de 2,36 mm ( 8 mesh) e 2,00 $\mathrm{mm}$ (9 mesh), sendo a partir de então caracterizados como "fino" (sem retenção), "médio" (9,26\% retido em peneira 2,36mm e 3,75\% retido em peneira $2,00 \mathrm{~mm}$ ) e "grosso" (93,78\% retido em peneira 2,36mm e 2,59\% retido em peneira 2,00 mm). Apesar da pequena solubilidade inicial da FOC $(0,26 \%$ de $\mathrm{P}_{2} \mathrm{O}_{5}$ solúvel em água), a produção gerada com o seu emprego (FOC granulometria média/Testemunha absoluta $=37,69 / 2,87=13,13 \mathrm{~g} \mathrm{~m}^{-2}$ ) não foi tão distante daquela gerada com o uso do superfosfato simples (SS/ Testemunha absoluta $=52,17 / 2,87=18,18 \mathrm{~g} \mathrm{~m}^{-2}$ ), podendo isso ser indicativo de seu potencial de uso (FERRO, CUNHA \& FERREIRA, 2013).

Em estudo de integração arroz-tifton 85 , avaliou-se os tratamentos de cultivo simultâneo e os plantios do capim aos 15, 30 e 45 dias após a implantação do arroz, além de suas monoculturas. Para o tratamento em que a fonte de fósforo foi a farinha de ossos calcinada $\left(375 \mathrm{~kg} \mathrm{ha}^{-1}\right)$, a produção de massa fresca e massa seca do capim foi mais elevada em condição de monocultura (2.420,0 e 797,6 kg ha ${ }^{-1}$ respectivamente). Os demais tratamentos não apresentaram diferenças estatísticas (média de 743,75 kg $\mathrm{ha}^{-1}$ de MF e 327,87 $\mathrm{kg} \mathrm{ha}^{-1}$ de MS), ou seja, tanto para a condição de plantio simultâneo como para a introdução em diferentes épocas, a fonte de 
fósforo não conseguiu atender às necessidades do capim. Mesmo os melhores resultados estão abaixo dos relatados na literatura (7 a $13 \mathrm{t} \mathrm{ha}^{-1} \mathrm{MF}$, por exemplo, em FERREIRA, 2013, citando outros autores).

Quando foi utilizado o superfosfoto triplo $\left(200 \mathrm{~kg} \mathrm{ha}^{-1}\right)$, os resultados foram diferentes. A maior produção em MF e MS do capim ocorreu no tratamento em monocultura (4973,3a e 1569,7a kg ha-1 de MF e MS, respectivamente), não sendo estatisticamente diferente de sua entrada simultânea ao cultivo do arroz (4740,0a e 1424,3a kg ha-1 de MF e MS, respectivamente). Sua introdução aos 15 dias após o plantio do arroz $(2433,3 \mathrm{~b}$ e 700,0b kg ha-1 de MF e MS, respectivamente) foi superior às demais, que não diferiram estatisticamente das introduções aos $30(1023,4$ c e 247,6c kg $\mathrm{ha}^{-1} \mathrm{de}$ MF e MS, respectivamente) e aos 45 dias (913,4c e 234,3c kg ha ${ }^{-1} \mathrm{de}$ MF e MS, respectivamente) após o plantio do arroz. O acúmulo de massa fresca e massa seca decrescente eram esperados em relação aos tratamentos com diferentes épocas de plantio (OLIVEIRA, 2013).

Para os dados referentes ao cereal (Arroz BRS Primavera), foram comprometidos com a ocorrência de bruzone (Pyricularia grisea (Cooke) Sacc.) gerando a falta de contraste entre os tratamentos, o menor número de panículas por metro quadrado (75,5 versus 98 ou 108 em relação a literatura), menor quantidade de grãos viáveis $(60,4 \%$ versus $89 \%)$ e produtividade $\left(1,1 \mathrm{t} \mathrm{ha}^{-1}\right)$, em comparação dessa mesma cultivar em sistema de plantio direto $\left(3,7 \mathrm{tha}^{-1}\right)$ ou mesmo convencional $\left(3,0 \mathrm{t} \mathrm{ha}^{-1}\right)$. Somente a média de 100 grãos $(2,5 \mathrm{~g})$ gerou resultados semelhantes aos encontrados na literatura (OLIVEIRA, 2013, citando outros autores).

Em estudo avaliando fontes (Super fosfato simples e Farinha de ossos calcinada) e doses (100, 200 e $300 \mathrm{~kg} \mathrm{ha}^{-1}$ de $\mathrm{P}_{2} \mathrm{O}_{5}$ total) para o capim Mombaça (Panicum maximum Jacq, de dezembro de 2012 a setembro de 2013) irrigado (uma lâmina única equivalente a 100\% da evapotranspiração potencial da cultura) em cinco cortes, com intervalos de 28 dias, a massa seca da parte aérea e a altura do dossel da forrageira, com o uso de farinha de ossos calcinada, proporcionou resultados intermediários por corte superiores em relação à produção de matéria seca $\left(1,73 \mathrm{tha}^{-1} \mathrm{corte}^{-1}\right)$ e altura das plantas $(55 \mathrm{~cm})$, quando comparado ao tratamento testemunha $(1,03$ 
t ha ${ }^{-1}$ corte $^{-1}, 35 \mathrm{~cm}$ respectivamente). Contudo, esse resultado foi inferior ao obtido quando o superfosfato simples foi utilizado (3,19 $\mathrm{t} \mathrm{ha}^{-1} \mathrm{MS}$ e 91 cm de altura). Em relação ao período experimental (202 dias), a farinha de ossos calcinada promoveu a produção de matéria seca acumulada em 54\% daquela observada com o uso de superfosfato simples (OLIVEIRA, 2014).

Para a dinâmica da produção da cultura, pode ser observado que o ponto mínimo de produção de matéria seca para ambas as fontes de $\mathrm{P}_{2} \mathrm{O}_{5}$ situou-se entre o $2^{\circ}$ e $3^{\circ}$ corte, ou seja, apesar das fontes de nutrientes e da irrigação, outras variáveis climáticas influenciaram decisivamente a produtividade da forrageira nesse período de estacionalidade (Figura 2). Discute o autor que temperaturas abaixo de $15^{\circ} \mathrm{C}$ e períodos de dias curtos (fotoperíodo) impedem o desenvolvimento das gramíneas forrageiras tropicais. Também as altas temperaturas (maiores que 30 a $35^{\circ} \mathrm{C}$ ) comprometem a produção de matéria seca devido ao fechamento dos estômatos. Entretanto, nas condições em que foi realizado este estudo, os fatores citados (temperatura e fotoperíodo) não podem ser considerados tão decisivos na influência da redução na produção de MS da forragem. Outros fatores e suas complexas interações passam a controlar o sistema. Por exemplo, umidade relativa e temperatura podem resultar na menor produção estacional.

A umidade relativa é importante porque está associada à taxa de transpiração, a qual, por sua vez, é proporcional à diferença da pressão de vapor entre os espaços intercelulares (que contêm ar) e a superfície da folha. Portanto, quando há uma atmosfera já carregada de vapor d'agua, a água dos tecidos é perdida muito mais devagar (RAVEN et al., 2007 apud OLIVEIRA, 2014) e, mesmo em condições irrigadas, se a umidade relativa do ar for baixa, sobretudo nas horas mais quentes do dia, as plantas podem diminuir a abertura dos estômatos para reduzir a atividade estomática e, com isso, reduzir a perda de água da planta para a atmosfera e evitar a desidratação do vegetal (PIMENTEL, 2004 apud OLIVEIRA, 2014). Ainda comenta o autor que a limitação do fluxo da água no sistema solo-planta-atmosfera se situa ao nível da absorção da água pelas raízes, pois o gradiente entre o solo e as raízes e a condutividade radicular máxima são bem menores que o gradiente e condutividade máximos entre a planta e a atmosfera. Para este estudo, 
considerando o intervalo entre os cortes (114 dias; do $1^{\text {o }}$ ao $5^{\circ}$ corte), $82 \%$ dos níveis de umidade relativa ficaram abaixo de $60 \%$, havendo dias em que atingiu 23\% de unidade relativa (UR). Em termos de comparação, para o caso da floresta Amazônica, os níveis médios de UR\% são de 84\% (LUIZÃO \& VASCONCELOS, 1999 apud OLIVEIRA, 2014) e as plantas que crescem em ambiente sombreado tipicamente apresentam grandes superfícies foliares, já que seu principal problema é obter luz suficiente e não perda de água (RAVEN et al., 2007, p. 668 apud OLIVEIRA, 2014). Também é importante ressaltar que na época seca se dá o início do ciclo reprodutivo das espécies forrageiras (emissão de panículas ou florescimento), época em que há uma interrupção do crescimento vegetal, por motivos fisiológicos (RASSINI, 2004 apud OLIVIERA, 2014).

Figura 2 - Produção de matéria seca da parte aérea do capim Mombaça submetido ao tratamento com superfosfato simples - SS (A) e farinha de ossos calcinada FOC (B) em função dos cortes. Rolim de Moura - RO, 2013. (**): significativo pelo teste $\mathrm{F}$ ao nível de $1 \%$ de probabilidade $(\mathrm{p}<0,01)$

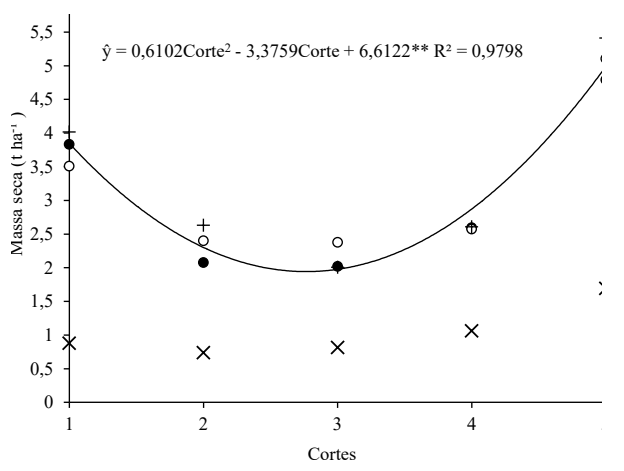

A

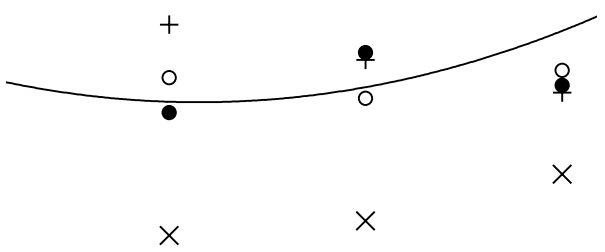

B

Fonte: OLIVEIRA, 2014. 
Já considerando a matéria seca acumulada, o uso da FOC promoveu aumento linear $(\mathrm{p}<0,01)$ para a produtividade em função do aumento das doses de $\mathrm{P}_{2} \mathrm{O}_{5}$ (Figura 2). Isso se deve à baixa solubilidade desse material $\left(0,26 \% \mathrm{P}_{2} \mathrm{O}_{5}\right.$ em $\left.\mathrm{H}_{2} \mathrm{O}\right)$, devido ao fato de o curto período para sua dissolução no solo não ter fornecido $\mathrm{P}$ suficiente para que a forrageira expressasse todo seu potencial, comparado aos tratamentos com SS. A melhor produtividade foi obtida quando se utilizou a dose de $400 \mathrm{~kg} \mathrm{ha}^{-1}$ de $\mathrm{P}_{2} \mathrm{O}_{5}$, tendo a forrageira produzido $9,4 \mathrm{tha}^{-1}$ durante o período experimental, ou seja, houve um aumento de produtividade de $81 \%$, comparando a dose aplicada de $400 \mathrm{~kg} \mathrm{ha}{ }^{-1}$ de $\mathrm{P}_{2} \mathrm{O}_{5}$ em relação à testemunha que não recebeu nenhuma fonte e dose de P. Para o SS, houve um aumento significativo $(\mathrm{p}<0,01)$ da produtividade de matéria seca com o aumento das doses, até a adição de $278 \mathrm{~kg} \mathrm{ha}^{-1}$ de $\mathrm{P}_{2} \mathrm{O}_{5}$ pela estimativa da regressão quadrática, que foi o modelo que melhor se ajustou com produção acumulada estimada de 18,4 t ha ${ }^{-1}$ de MS nos cinco cortes (ponto de máximo da curva), representando um acréscimo de 283\% em relação à testemunha (Figura 3).

Figura 3 - Massa seca acumulada da parte aérea do capim Mombaça em função das fontes (Superfosfato simples - SS e Farinha de ossos calcinada - FOC) e doses aplicadas. Rolim de Moura-RO. (**) Significativo pelo teste F ao nível de 1\% de probabilidade $(\mathrm{p}<0,01)$

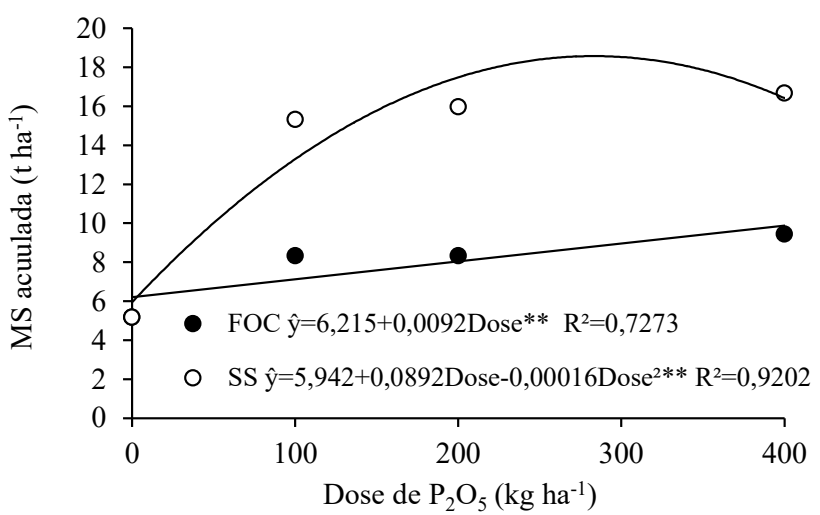

Fonte: OLIVIERA, 2014.

Neste mesmo estudo, se procedeu à avaliação radicular do capim Mombaça aos 90 dias após a semeadura da forrageira (90 DAS) e aos 230 dias do período experimental (230 DAS). Para tanto, foram retiradas 
amostras nas camadas de 0-5 e 5-20 cm, na base da touceira da forrageira, com o uso de cilindros metálicos.

Para a primeira avaliação (90 DAS), foi observado efeito significativo para doses como também interação entre fontes e doses nas duas profundidades. Para a segunda avaliação (230 DAS), ocorreu apenas efeito significativo para doses na profundidade 0-5 cm (EVALD, 2014).

Pela análise de regressão da densidade radicular (0-5 cm, 90 DAS), obteve-se efeito significativo quadrático $(\mathrm{p}<0,01)$, tanto para as doses de supersimples como para farinha de ossos calcinada (Figura 4). A máxima concentração de raízes foi estimada na dosagem de 237,5 $\mathrm{kg} \mathrm{ha}^{-1}$ de $\mathrm{P}_{2} \mathrm{O}_{5}$ na forma de SS, enquanto sua maior dose (400 kg ha-1 de $\left.\mathrm{P}_{2} \mathrm{O}_{5} \mathrm{SS}\right)$ promoveu uma das menores densidades, superior apenas em relação ao testemunho. Para a FOC, a dose de $400 \mathrm{~kg} \mathrm{ha}^{-1}$ de $\mathrm{P}_{2} \mathrm{O}_{5}$ apresentou maior densidade radicular (DR).

Já na interação entre doses e fontes, foi observado que as doses 100 e $200 \mathrm{~kg} \mathrm{ha}^{-1} \mathrm{de} \mathrm{SS}$, na profundidade $0-5 \mathrm{~cm}$, apresentou efeito estatístico significativo em relação às mesmas doses de FOC (Tabela 8), apresentando maiores densidades de raízes. Para a profundidade $5-20 \mathrm{~cm}$, foi observado comportamento similar. A dose que promoveu máxima densidade de raiz foi estimada em 212,5 $\mathrm{kg} \mathrm{ha}^{-1}$ de $\mathrm{P}_{2} \mathrm{O}_{5}$ na fonte $\mathrm{SS}$ (Figura 4). Já em relação à FOC, a dose de maior DR foi de $250 \mathrm{~kg} \mathrm{ha}^{-1}$ de $\mathrm{P}_{2} \mathrm{O}_{5}$. Apesar da similaridade, tais resultados se relacionam aos níveis nutricionais, induzindo o comportamento radicular em relação ao modo de aplicação e à solubilidade das fontes de nutrientes utilizadas (EVALD, 2014). Apesar da diferença de solubilidade em água (85\% para SS e 0,26\% para FOC), registra-se a importância de fontes de baixa solubilidade de fosfato, no sentido de proporcionar uma fosfatagem corretiva, com o propósito de diminuir o poder de adsorção de $\mathrm{P}$ dos solos, de modo a viabilizar maior eficiência de futuras aplicações de fontes solúveis (NOVAIS, 1999 apud EVALD, 2014). 
Figura 4 - Efeito de doses de superfosfato simples sobre a densidade radicular de Panicum maximumcv. Mombaça nas profundidades $0-5 \mathrm{~cm}$ e $5-20 \mathrm{~cm}$ aos 90 DAP. **Significativo pelo teste $\mathrm{F}$ ao nível de $1 \%$ de probabilidade $(\mathrm{p}<0,01)$

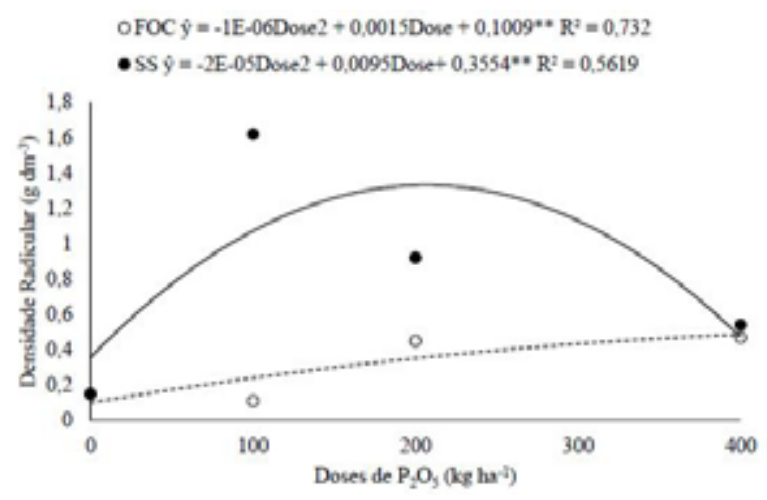

Fonte: EVALD, 2014.

Tabela 8 - Valores médios de densidade de raiz $\left(\mathrm{g} \mathrm{dm}^{-3}\right)$ de capim Mombaça 90 DAS, em duas profundidade (0-5 e 5-20 cm) adubado com farinha de ossos calcificada (FOC) e superfosfato simples (SS), com diferentes níveis de adubação.

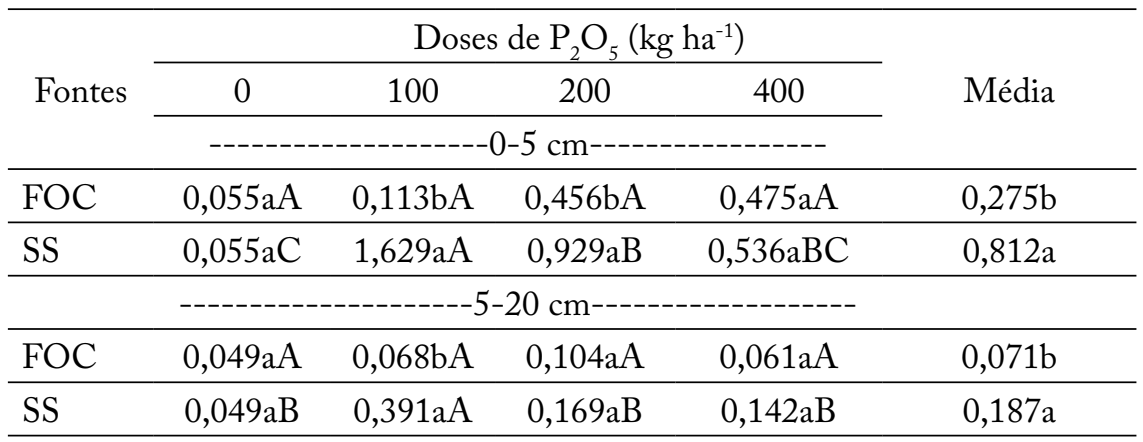

Médias seguidas de letras maiúsculas diferentes na linha e médias seguidas de letras minúsculas diferentes na coluna diferem pelo teste de Tukey $(\mathrm{p}<0,05)$, para ambas as profundidades.

Fonte: Evald (2014).

Avaliando a correlação estatística, obteve-se que não houve significância entre densidade radicular (DR) e produção de matéria seca da parte aérea do Mombaça quando o superfosfato simples foi usado. Contudo, observou-se correlação significativa, ao nível de $5 \%$ de probabilidade $(\mathrm{r}=$ $\left.0,64^{*}\right)$, quando a farinha de ossos calcinada foi utilizada. Possivelmente, esse resultado está relacionado aos níveis de reserva em nutrientes da planta, 
sendo que, para o fósforo oriundo da FOC, não foram suficientes para gerar reservas que tornassem a planta temporalmente "independente" do sistema radicular (EVALD, 2014).

O sistema radicular está em constante interação com a parte aérea, o que o torna um dos responsáveis pelo desenvolvimento da planta, além de se constituir na fonte de carboidratos e proteínas para o início da rebrotação dos capins. Um sistema radicular vigoroso reduz o tempo de rebrota das plantas, diminuindo os ciclos de pastejo, e eleva a produção anual da planta forrageira, além de aumentar a resistência das gramíneas ao estresse hídrico e sua competitividade por nutrientes (CECATO et al., 2001 apud EVALD, 2014).

Para a avaliação da densidade radicular aos 230 DAP, na profundidade de $0-5 \mathrm{~cm}$, observou-se efeito significativo linear $(\mathrm{p}<0.01)$ para o fator doses, tanto de superfosfato simples quanto de farinha de ossos calcinada (Figura 5). Diferentemente da primeira avaliação (90 DAP, efeito quadrático), essa resposta linear pode estar relacionada temporalmente à dinâmica do fator capacidade (P-lábil/P-solução) do sistema solo (EVALD, 2014). É interessante lembrar que, nessa dinâmica, a fonte de fósforo representada pelo superfosfato simples apresenta $85 \%$ de solubilidade em água a $25^{\circ} \mathrm{C}$ e gera $\mathrm{pH}$ entre 2,5 a 3,0, nessa mesma condição (COOPEBRAS, 2003 apud EVALD, 2014), enquanto a farinha de ossos calcinada possui uma solubilidade de 0,26 e gera um pH da 10,6 (EVALD, 2014).

Figura 5 - Efeito de doses de superfosfato simples e farinha de ossos calcinada sobre a densidade radicular de Panicum maximum cv. Mombaça na profundidade 0-5 cm aos 230 DAP. **ignificativo pelo teste $\mathrm{F}$ ao nível de $1 \%$ de probabilidade $(\mathrm{p}<0,01)$.

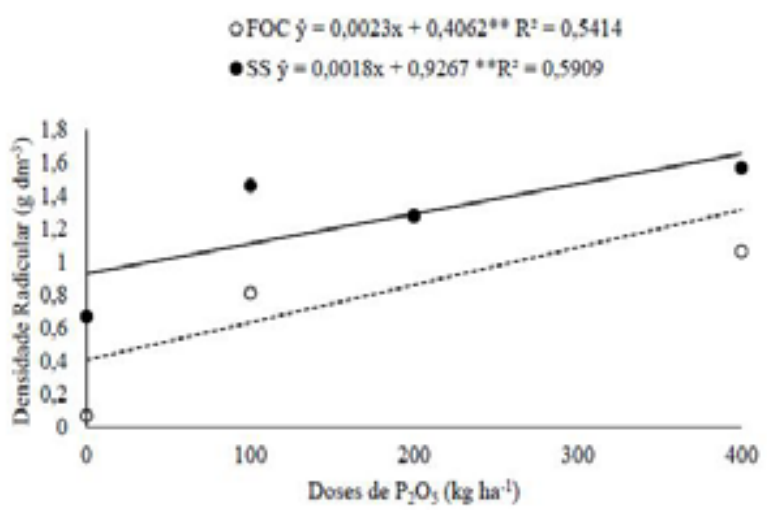


Em termos de manejo de recursos fosfatados para formação de pastos, tem-se a recomendação de que as fontes de maior solubilidade sejam aplicadas na linha de plantio, no sentido de promover o estabelecimento da forrageira. A fonte de menor solubilidade deve ser aplicada em área total, a fim de que, com sua solubilização temporal, possa promover a persistência da forragem no sistema de pastagem. O emprego de fontes alternativas de adubação ou correção de solo ainda carece de estudos. Por exemplo, para produção do capim Mombaça - em relação ao uso de "calcário líquido" com superfosfato simples ou calcário em pó com farinha de ossos calcinada -, conduziu-se um estudo combinando dois níveis de fosfato no solo (100 e $400 \mathrm{~kg} \mathrm{ha}^{-1}$ ), sendo usadas duas fontes (supersimples e farinha de ossos calcinada) combinadas com cinco níveis de cálcio $\left(0,0,5 ; 1,0 ; 1,5\right.$ e $\left.2 \mathrm{t} \mathrm{ha}^{-1}\right)$, nas formas de calcário em pó e de fertilizante líquido para uso em solo (“calcário líquido"). Esse experimento foi conduzido a campo, e todas as parcelas receberam as mesmas quantidades de nitrogênio (125 kg ha-1) e potássio $\left(34,5 \mathrm{~kg} \mathrm{ha}^{-1}\right)$, exceto o tratamento testemunha. O capim Mombaça apresentou melhores desempenhos em matéria seca $\left(1,74 \mathrm{a} \mathrm{kg} \mathrm{ha}{ }^{-1}\right)$, fresca e altura $(1,34 \mathrm{~m})$ de plantas no tratamento, quando foram empregados $400 \mathrm{~kg} \mathrm{ha}^{-1}$ de $\mathrm{P}_{2} \mathrm{O}_{5}$ na forma de superfosfato simples associado a $1 \frac{1}{2} \mathrm{da}$ dose recomendada para se atingir $\mathrm{V} \%=60$, na forma de calcário líquido.

As menores respostas em produção foram geradas para os tratamentos com $400 \mathrm{~kg} \mathrm{ha}^{-1}$ com farinha de ossos calcinada e $1 / 2$ da dose de calcário em pó $\left(0,47 \mathrm{~b} \mathrm{~kg} \mathrm{ha-1} \mathrm{MS)} \mathrm{e} \mathrm{a} \mathrm{testemunha}\left(0,44 \mathrm{~b} \mathrm{~kg} \mathrm{ha}{ }^{-1} \mathrm{MS}\right.\right.$ e $0,57 \mathrm{~m}$ de altura). Os demais tratamentos obtiveram valores intermediários (ab) quando analisados pelo teste de Tukey (5\%) de probabilidade (RODRIGUES et al., 2013).

Neste estudo também se procedeu à avaliação do sistema radicular (240 DAS) que, em relação aos tratamentos não se obteve diferenças significativas entre os efeitos das fontes de fósforo e cálcio sobre a produção de matéria seca da raiz (MSR, média geral =0,9312 $\pm 0,4543 \mathrm{~g} \mathrm{dm}^{-3}$ ) na camada de 0-5 cm. Tal comportamento também foi verificado em Brachiaria brizantha $\mathrm{cv}$. Xaraés sob doses de nitrogênio e fósforo (RODRIGUES 
et al., 2012 apud CRUZ, 2014) e em Panicum maximum cv Tanzânia (PATÊS et al., 2008 apud CRUZ, 2014).

Para MSR na camada de 5-20 cm, houve diferenças significativas ( $\mathrm{p}<0,05)$ utilizando-se a maior dose de fósforo $\left(400 \mathrm{~kg} \mathrm{ha}^{-1}\right)$ na forma de supersimples (SS) juntamente com $1 / 2$ de calcário líquido $\left(0,2426 \mathrm{a} \mathrm{g} \mathrm{dm}^{-3}\right)$, que apresentou um aumento de cerca de 143\%, quando comparado ao tratamento com as mesmas doses, mas com o uso de FOC e calcário em pó $\left(0,0997 \mathrm{ab} \mathrm{g} \mathrm{dm}^{-3}\right)$, não diferindo da testemunha absoluta $\left(0,0486 \mathrm{~g} \mathrm{dm}^{-3}\right)$. O pior resultado $\left(0,0149 \mathrm{~b} \mathrm{~g} \mathrm{dm}^{-3}\right)$ ocorreu para o tratamento com $100 \mathrm{~kg}$ de FOC associado a 2 t de calcário em pó (CRUZ, 2014).

Em relação à dinâmica de distribuição de raízes, é importante salientar que, para o capim Mombaça, a maior concentração de raízes ocorre nas camadas iniciais do solo e em menores quantidades nas camadas inferiores, ocasionado principalmente pela maior concentração de nutrientes nessa região. As plantas do gênero da Brachiaria, por outro lado, apresentam maior quantidade e melhor distribuição de raízes em profundidade, quando comparadas a plantas de Panicum e de Andropogon, gerando assim maior capacidade de produção de raízes e, consequentemente, maior oportunidade de absorção de água e de nutrientes (KANNO et al., 1999 apud CRUZ, 2014).

Quanto ao emprego dessas fontes não usuais, deve ser considerado que, para o calcário líquido, tem-se a facilidade de aplicação e uso de um menor quantitativo, no tocante a mão-de-obra etc. Certamente seu efeito é efêmero, já que não possui poder residual comparado ao calcário em pó. Para as fontes de fósforo, se depara com os efeitos de solubilidade, uma vez que a farinha de ossos calcinada conta com apenas $0,26 \%$ de $\mathrm{P}_{2} \mathrm{O}_{5}$ solúvel em água. Contudo, essas duas fontes merecem atenção da pesquisa, já que o produtor tem intenção de empregá-las a fim de reduzir seu custo. Os dados ora apresentados foram gerados com base em uma única coleta (aos 120 dias após a semeadura); outros cortes não foram realizados porque o capim não apresentou suficiente crescimento com o início da estacionalidade. Para as condições da Amazônia Ocidental e, em especial, Rondônia (Aw e Am Koppen), não há importantes limitações quanto à luminosidade (acima de 
$300 \mathrm{cal} \mathrm{cm}^{-2} \mathrm{dia}^{-1}$ ) para que o crescimento de Panicum fique comprometido, tampouco temperatura, uma vez que, em período seco, temperaturas mínimas superiores a $15,5{ }^{\circ} \mathrm{C}$ permitem satisfatório crescimento da forrageira. Assim, espera-se que, em condições de forragens irrigadas, no período seco do ano, os efeitos dos diferentes tratamentos ora relatados possam apresentar maiores contrastes (RODRIGUES et al, 2013 citando outros autores; CRUZ, 2014). É importante ressaltar que os autores conhecem e concordam com os questionamentos técnicos emitidos sobre o uso do calcário líquido de forma não científica pelo Instituto Agronômico de Campinas e pela Sociedade Brasileira de Ciência do Solo. Mas esse trabalho teve sua importância na oportunidade de confrontar as expectativas geradas na sociedade em relação aos produtos e proporcionar ao discente formação crítica quanto ao correto emprego dos insumos disponíveis no mercado. Alguns registros fotográficos das avaliações relatadas neste capitulo estão apresentadas nas figuras 6 e 7 .

Figura 6 - Experimentos com farinha de ossos. Farinha de carne e ossos em capim Marandu, vista geral de experimento (NICOLAU, 2011); - A) Farinha de ossos calcinada na produção do capim elefante cv Paraíso (ARVELINO, 2011); - B) parcelas de capim Marandu submetidas ao estresse hídrico após 90 dias de corte (NICOLAU, 2011); - C) sintomatologia condizente com deficiência de fósforo em tifton com $100 \mathrm{~kg} \mathrm{ha}^{-1} \mathrm{P}_{2} \mathrm{O}_{5}$ de FOC (BALBINO, 2011); - D) Arroz BRS Primavera consorciado com o capim Cynodon dactylon cv. Tifton 85 (30/01/12) (OLIVEIRA, 2013); - E); vista geral do experimento de integração de arroz com o capim Tifton 85 (FERREIRA, 2014 - F).

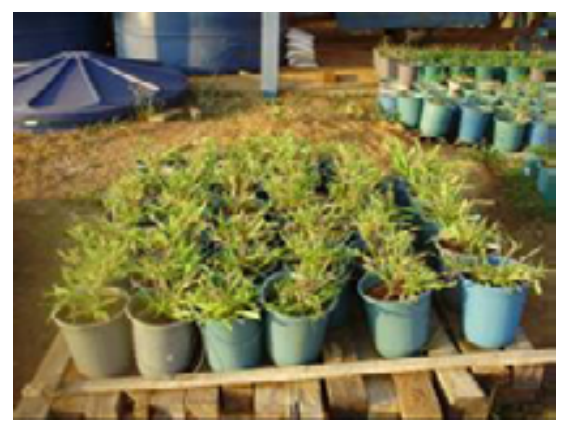

A

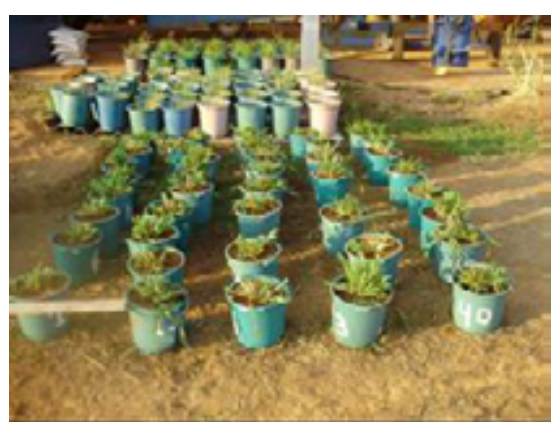

B 


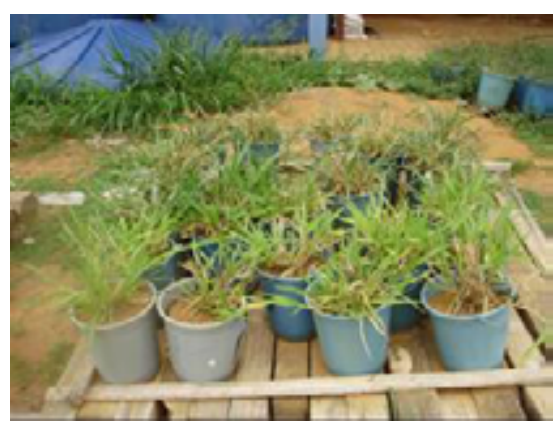

$\mathbf{C}$

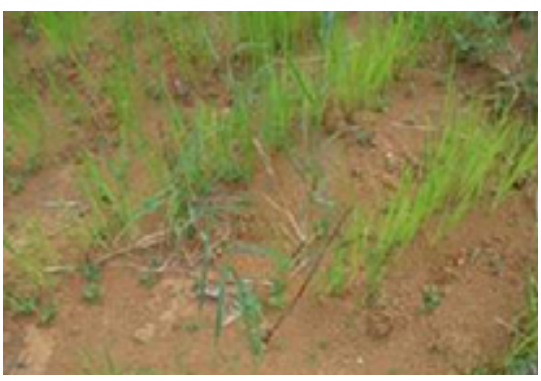

$\mathbf{E}$

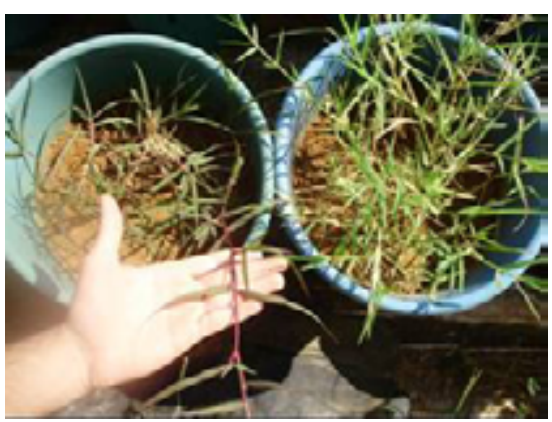

D

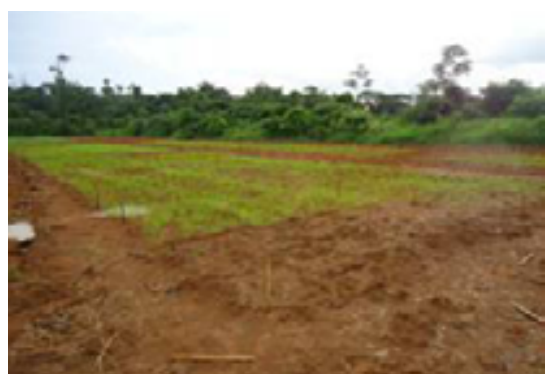

F

Figura 7 - Experimentos com farinha de ossos calcinada em Stylosanthes Campo Grande (FERRO, CUNHA, FERREIRA, 2013) - A) em capim Panicum maximum cv Mombaça avaliando fontes alternativas de fósforo e cálcio (RODRIGUES, 2013); - B) também em relação à parte aérea (OLIVEIRA, 2014) - C) e raízes (EVALD, 2014) - D) do capim Mombaça irrigado. Detalhe na concentração de raízes do Mombaça irrigado com o uso de $100 \mathrm{~kg} \mathrm{ha}^{-1}$ de superfosfato simples (E) em relação ao emprego da farinha de ossos calcinada na mesma dosagem (EVALD, 2014) - F) em trincheira com exposição de $100 \mathrm{~cm}$ de profundidade.

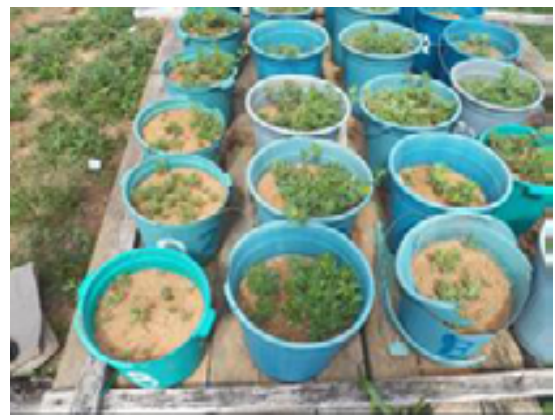

A

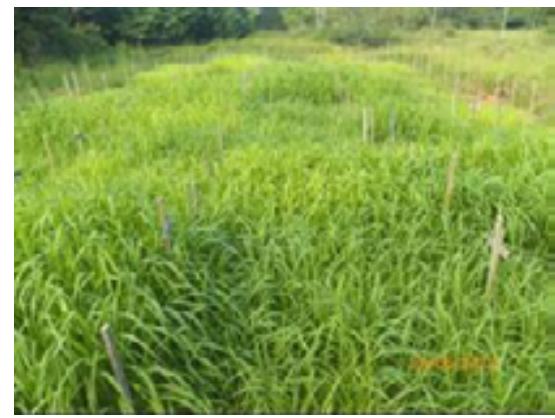

B 


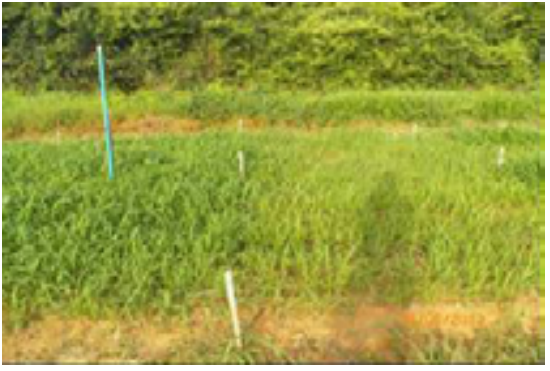

C

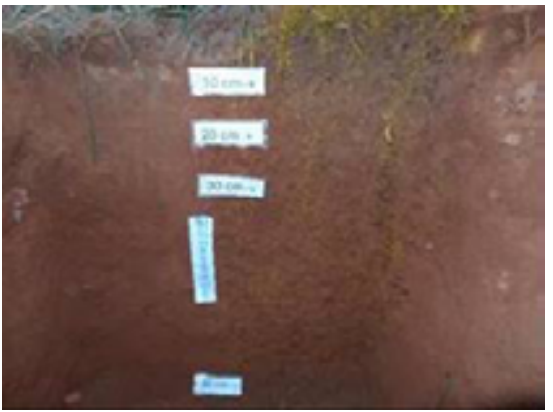

E

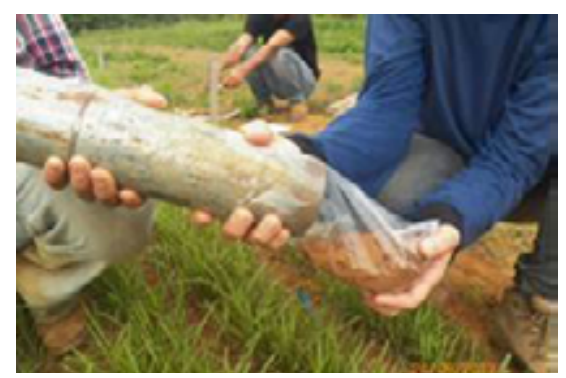

D

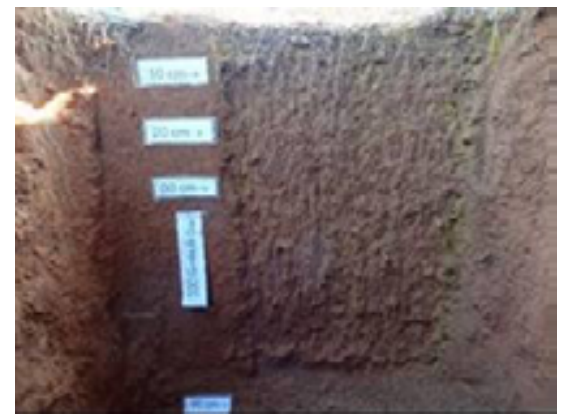

F

\section{Referências}

ARAUJO, A. P.; MACHADO, C. T. T. Fósforo. In: FERNANDES, M. S.(Ed.). Nutrição Mineral de Plantas. Viçosa, MG: Sociedade Brasileira de Ciência do Solo, 2006, p. 253280, 432 p.: il.

ARVELINO, G. M. Uso da farinha de ossos calcinada na produção do capim elefante (Pennisetum purpureum Schum.). Rolim de Moura, RO. 2011. 30 f. Monografia (Graduação em Agronomia), Universidade Federal de Rondônia, Rolim de Moura, RO.

BALBINO, T. G. M. Farinha de ossos calcinada como fonte de fósforo para o capim tifton (Cynodon dactilon L.). Rolim de Moura, RO. 2011. 29 f. Monografia (Graduação em Agronomia), Universidade Federal de Rondônia, Rolim de Moura, RO.

CANTARUTTI, R. B. et al. Pastagens. In: RIBEIRO et al. (Eds.). Recomendações para o uso de corretivos e fertilizantes em Minas Gerais. 5a Aproximação Comissão de fertilidade do solo do Estado de Minas Gerais. Viçosa, MG, 1999. 359p.: Il.

CORSI, M. Exigências nutricionais de plantas forrageiras em pastagens (49-64). In: PEIXOTO, A. M. (Ed.). Pastagens: fundamentos da exploração racional. 2.ed. Piracicaba: FEALQ, 1994. 908 p.: Il (FEALQ. Série atualizada em Zootecnia, 10). 
CRUZ, W. S. Quantificação do sistema radicular do capim Mombaça submetido a fontes alternativas de cálcio e fósforo. Rolim de Moura, RO. 2014. 38 f. Monografia (Graduação em Agronomia). Universidade Federal de Rondônia, Rolim de Moura, RO.

EVALD, A. Densidade radicular do capim Mombaça irrigado submetido a farinha de ossos calcinada. Rolim de Moura, RO. 2014. 47 f. Monografia (Graduação em Agronomia). Universidade Federal de Rondônia, Rolim de Moura, RO.

FERREIRA, A. V. L. Integração lavoura-pecuária: estudo de caso arroz tifton 85 com farinha de ossos calcinada como fonte de fósforo. Rolim de Moura, RO. 2013. $31 \mathrm{f}$. Monografia (Graduação em Agronomia). Universidade Federal de Rondônia, Rolim de Moura, RO.

FERREIRA, E; BALBINO, T. Carta de cores para a avaliação qualitativa da farinha de ossos calcinada. Instituto Nacional de Propriedade Industrial, Diretoria de Patentes. Submetido em 07.04.2014. Protocolo: BR2020140083923.

FERRO, L. A. B.; CUNHA, J. B.; FERREIRA, E. Farinha de ossos calcinada no desempenho agronômico de estilosantes Campo Grande. CONGRESSO INTERNACIONAL DO LEITE, 12, 2013, Porto Velho, RO. Anais... XII Congresso Internacional do Leite:XII Workshop de Políticas Públicas: XIII Simpósio de Sustentabilidade da Atividade Leiteira- Brasília, DF: Embrapa, 2013. CD-ROM; 4 3/4 pol.

LOBATO, E.; KORNELIUS, E.; SANZONOWICZ, C. Adubação Fosfatada em Pastagens (155-188). In: PEIXOTO, A. M. (Ed.). Pastagens: fundamentos da exploração racional. 2.ed. Piracicaba: FEALQ, 1994. 908 p.: Il (FEALQ. Série atualizada em Zootecnia, 10).

MALAVOLTA, E., LIEM, T. H., PRIMAVESI, A. C. P. A. Exigências nutricionais das plantas forrageiras. In: MATTOS et al. (Eds.). Calagem e adubação de pastagens. (p.3176. Piracicaba: Associação Brasileira para Pesquisa da Potassa e do Fosfato, 1986. 476p.: Il.

NICOLAU, C. H. F. Farinha de carne e ossos como fonte de fósforo para Braquiaria (Brachiaria brizantha cv. Marandu). Rolim de Moura, RO. 2011. 34 f. Monografia (Graduação em Agronomia). Universidade Federal de Rondônia. Rolim de Moura, RO.

NOVAES, R. F.; SMYTH, T. J.; NUNES, F. N. VIII - Fósforo (p. 471-550) In: NOVAIS et al. (Eds.). Fertilidade do Solo. Viçosa, MG. Sociedade Brasileira de Ciência do Solo. 2007. 1017 p.: Il.

OLIVEIRA, J. W. Farinha de ossos calcinada na produção do capim Mombaça irrigado na Amazônia Ocidental. Rolim de Moura, RO. 2014. 40 f. Monografia (Graduação em Agronomia). Universidade Federal de Rondônia, RO.

OLIVEIRA, R. V. Integração lavoura-pecuária: estudo de caso arroz associado com tifton 85. Rolim de Moura, RO. 2013. 32 f. Monografia (Graduação em Agronomia). Universidade Federal de Rondônia, Rolim de Moura, RO.

RODRIGUES, T. C. J.; TRASPADINI, E. I. F.; DIAS, J. R. M.: FERREIRA, E. Avaliação de fontes não convencionais de cálcio e fósforo na produção de capim Mombaça em área degradada. CONGRESSO INTERNACIONAL DO LEITE, 12, 2013. Porto Velho, RO. 
Anais... XII Congresso Internacional do Leite: XII Workshop de Políticas Públicas: XIII Simpósio de Sustentabilidade da Atividade Leiteira.- Brasília, DF: Embrapa, 2013. CDROM; 4 3\%4 pol.

SANTOS, B. R. V. et al. Correlação do P no sistema solo-planta-animal em pastagem natural na Região da Campanha - RS. Archivos de Zootecnia, Cordoba, v. 59, n. 228, 2010.

SIMÕES, A. C.; CRUZ, I. V.; CRUZ, C. V., SOUZA; K. G., SOUZA; E. F. M.; DIAS, J. R. M.; FERREIRA, E. Meat and bone meals in agronomy performance of tifton. International Journal of Agriculture and Foresty, v. 2, n. 2, 78-83, 2012.

SIMÕES, A. C. Farinha de carne e ossos no desempenho agronômico do capim tifton. Rolim de Moura, RO. 2011. 30 f. Monografia (Graduação em Agronomia). Universidade Federal de Rondônia. Rolim de Moura, RO.

SIQUEIRA, C. Calagem para plantas forrageiras. In: MATTOS et al. (Eds.). Calagem e adubação de pastagens. (p.85. Piracicaba: Associação Brasileira para Pesquisa da Potassa e do Fosfato, 1986. 476p.: Il.

SOUZA, C. H. E. Absorção de nitrato e amônio por gramíneas forrageiras com tolerância diferencial ao alumínio e baixa disponibilidade de fósforo. 2003. Dissertação (Mestrado), Viçosa: UFV, 61p. il, 2003.

WERNER, J. C. Calagem para plantas forrageiras. In: PEIXOTO et al. Pastagens: Fundamentos da exploração racional. 2.ed. Piracicaba: FEALQ 1994. p.111-119; (FEALQ: Série atualização em zootecnia, 10). 908p. il. 


\section{POTENCIAL DE EMPREGO DA FARINHA DE OSSOS CALCINADA ACIDIFICADA NA HORTICULTURA: ESTUDO DE CASO - RÚCULA}

Anna Frida Hatsue Modro

Emanuel Maia

Sheyla Ariene Ramos de Campos

\section{Introdução}

Em diversas atividades de processamento de produtos agropecuários, a geração de resíduos constitui-se em sérios problemas ambientais e, para sua mitigação, são gerados custos adicionais (ROSCOE, 2010). Em 2002, nos abatedouros de bovinos, foram produzidos aproximadamente quatro milhões de toneladas em produtos não comestíveis e ou recicláveis, como as farinhas de carne e ossos e gordura animal (BELLAVER, 2002).

Esses resíduos possuem potencial como fertilizante para a agricultura, pois podem conter altas quantidades de nitrogênio e fósforo (PACHECO, 2006). Estudos indicam que a farinha de ossos, por exemplo, possui concentrações de $14 \%$ de nitrogênio e $27 \%$ de fósforo, dependendo dos produtos que a originaram (CAVALLARO JÚNIOR, 2006). Entretanto, os valores de fosfatos podem estar situados entre $24 \%$ até $35 \%$, dependendo do processamento (autoclavagem, desengorduração, degelatinização ou calcificação) dos ossos bovinos (KIEHL, 1985).

Assim, a prática de transformar esses resíduos em insumos para a agricultura tem o potencial de gerar ganhos ecológicos, econômicos e sociais (ROSCOE, 2010), podendo apresentar fontes alternativas de adubos para uso agrícola, reduzindo a dependência e os impactos ambientais negativos dos fertilizantes industrializados provenientes de lavras naturais, o que tem sido incentivado na pesquisa agropecuária (FREITAS, 2010).

Embora a farinha de ossos calcinada (FOC) represente uma fonte alternativa de fósforo (SATELIS, 2010; BALBINO, 2011; EVALD, 2014), 
seu efeito como fertilizante depende, também, de fatores inerentes ao solo, clima e práticas culturais, principalmente em relação à disponibilidade dos nutrientes para a planta (SANTOS e KLIEMANN, 2005). Dessa maneira, considerando que a FOC é um fertilizante fosfatado pouco solúvel em água, porém solúvel em ácidos fracos (i.e. ácido cítrico e citrato neutro de amônio) (KIEHL, 1985), objetivou-se, neste trabalho, avaliar o crescimento da rúcula fertilizada com farinha de ossos calcinada, tratada com diferentes concentrações de ácido acético.

\section{Material e métodos}

O ensaio foi conduzido na Fazenda Experimental da Universidade Federal de Rondônia, no município de Rolim de Moura. O local do experimento encontra-se a $277 \mathrm{~m}$ acima do nível do mar, em latitude 11³4'58,60" S e longitude 6146’22,30” O. O clima, segundo classificação de Köppen, é tropical-quente e úmido (Aw), com estação seca bem definida, temperatura mínima de $24^{\circ} \mathrm{C}$, máxima de $32^{\circ} \mathrm{C}$, e temperatura média de $28^{\circ} \mathrm{C}$, com precipitação anual média de $2.250 \mathrm{~mm}$ e com umidade relativa do ar elevada, oscilando em torno de 85\% (PEEL et al., 2007).

O solo utilizado no experimento é do tipo Latossolo Vermelho Amarelo Distrófico e, de acordo com análise de solo, apresenta os seguintes atributos químicos e físicos: $\mathrm{pH}$ em água $=4,8$; matéria orgânica $=12 \mathrm{~g}$ $\mathrm{kg}^{-1} ; \mathrm{P}_{\text {Mehlich }}{ }^{-1}=1,5 \mathrm{mg} \mathrm{dm}^{-3} ; \mathrm{K}_{\text {Mehlich }}{ }^{-1}=0,09 \mathrm{cmol}_{\mathrm{c}} \mathrm{dm}^{-3} ; \mathrm{Ca}=0,6 \mathrm{cmol}_{\mathrm{c}} \mathrm{dm}^{-3}$; $\mathrm{Mg}=0,2 \mathrm{cmol}_{\mathrm{c}} \mathrm{dm}^{-3} ; \mathrm{Al}=0,3 \mathrm{cmol}_{\mathrm{c}} \mathrm{dm}^{-3} ; \mathrm{H}+\mathrm{Al}=3,9 \mathrm{cmol}_{\mathrm{c}} \mathrm{dm}^{-3} ; \mathrm{SB}=0,9$ $\mathrm{cmol}_{\mathrm{c}} \mathrm{dm}^{-3} ; \mathrm{T}=4,8 \mathrm{cmol}_{\mathrm{c}} ; \mathrm{V}=18,8 \% ;$ Argila=610 g kg; Silte=130 g kg; Areia $=260 \mathrm{~g} \mathrm{~kg}$.

A saturação por bases do solo foi corrigida para $80 \%$, utilizando calcário dolomítico com PRNT 100\%, e as quantidades dos fertilizantes e corretivos aplicados encontram-se descritos na Tabela 1. A adubação de plantio foi realizada com a aplicação dos fertilizantes, 15 dias antes da semeadura da rúcula.

O experimento foi conduzido de maio a junho de 2014, em vasos plásticos de $15 \mathrm{~L}$, com um vaso por parcela. Foram utilizadas sementes 
de rúcula (Eruca sativa Mill. cv. 'Apreciatta Folha Larga'), peletizadas com 0,15\% de captan, $89 \%$ de germinação e $100 \%$ de pureza. O semeio foi na profundidade de $0,5 \mathrm{~cm}$, com espaçamento de $15 \mathrm{~cm}$ entre linhas e $5 \mathrm{~cm}$ entre plantas, utilizando duas sementes por cova. Cinco dias após a germinação, foi realizado desbaste, conservando seis plantas por vaso. A irrigação das plantas foi realizada mantendo-se a mesma quantidade de água por vaso, com regas diárias.

Tabela 1 - Quantidades e épocas de aplicação dos fertilizantes e corretivos em cultivo da rúcula.

\begin{tabular}{|c|c|c|c|c|}
\hline \multirow{3}{*}{ Fonte } & \multirow{3}{*}{$\begin{array}{c}\text { Adubação de } \\
\text { plantio } \\
\left(\text { g vaso }^{-1}\right)\end{array}$} & \multirow{2}{*}{\multicolumn{3}{|c|}{ 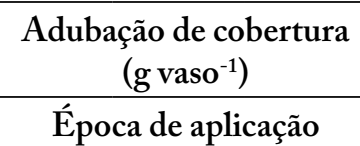 }} \\
\hline & & & & \\
\hline & & 7 dias & 14 dias & 21 dias \\
\hline Ureia 0,75 & 0,75 & 0,75 & 0,75 & 0,75 \\
\hline Cloreto de potássio & 0,51 & 0,51 & 0,77 & 0,77 \\
\hline Superfosfato simples & 16,60 & - & - & - \\
\hline Farinha de ossos calcinada & 7,56 & - & - & - \\
\hline Calcário & 22 & - & - & - \\
\hline
\end{tabular}

Ureia (44\% N); Cloreto de potássio $\left(58 \% \mathrm{~K}_{2} \mathrm{O}\right)$; Superfosfato simples $\left(18 \% \mathrm{P}_{2} \mathrm{O}_{5}\right)$; Farinha de ossos calcinada $\left(35,7 \% \mathrm{P}_{2} \mathrm{O}_{5}\right)$.

Utilizou-se delineamento inteiramente casualizado, com quatro repetições e cinco tratamentos, que consistiram na aplicação da farinha de ossos calcinada tratada com diferentes concentrações de ácido acético, a saber: $0,15,30$ e $60 \%$, e um tratamento controle, com superfosfato simples.

A solução acética foi preparada com ácido acético PA, em um volume correspondente a $50 \%$ do total da massa de farinha de ossos calcinada a ser aplicada em cada tratamento. Após a aplicação da solução acética sobre a farinha de ossos, a mesma foi homogeneizada e levada à estufa de circulação forçada de ar à temperatura de $65^{\circ} \mathrm{C}$ até atingir massa constante. $\mathrm{A}$ quantidade de farinha de ossos calcinada aplicada foi calculada pela necessidade de atender as demandas da planta, utilizando a concentração total de fósforo (Tabela 1). 
O experimento foi colhido ao $32^{\circ}$ dia após o plantio, sendo utilizadas duas plantas como parcela útil, onde se avaliou o comprimento de folha, número de folhas, área foliar, matérias fresca e seca. O comprimento da folha foi aferido do pecíolo ao ápice da maior folha da planta, com o uso de régua graduada de $01-30 \mathrm{~cm}$. Para determinação da biomassa foi quantificada a massa da matéria fresca e, após o material ser acondicionado em sacos de papel identificados, estes foram levados à estufa de circulação forçada de ar com temperatura de $65^{\circ} \mathrm{C}$ durante 72 horas, para determinação da massa da matéria seca. $\mathrm{O}$ número de folhas foi obtido em cada planta útil e calculada a média por parcela. A determinação da área das folhas foi feita por meio de imagens digitalizadas em scanner de mesa, na resolução de 100 dpi e salvas como imagem monocromática tipo bitmap, com o auxílio do software DDA - Determinador Digital de Áreas (FERREIRA et al., 2008). Os sintomas de deficiência de fósforo foram avaliados conforme literatura específica, como Ferreira (2012).

Os dados foram submetidos à análise de variância. Quando necessário, foi realizada a análise de regressão para avaliar os efeitos das doses de ácido acético (AA). A comparação com o tratamento controle (adubação com superfosfato simples) foi realizado com o emprego do teste de Dunnett. Para auxiliar nas análises estatísticas, utilizou-se o software livre R (R CORE TEAM, 2015).

\section{Resultados e discussão}

Os resultados demonstram efeitos significativos em relação às fontes de adubação utilizadas. O tratamento com superfosfato simples resultou em maiores valores para as variáveis avaliadas quando comparados aos tratamentos com farinha de ossos calcinada, acidificada ou não (Tabela 2). Tal resultado indica que o possível aumento na disponibilidade do fósforo na FOC, proporcionada pela acidificação em até $60 \%$ AA, não foi suficiente para atender as demandas de pleno crescimento da rúcula. 
Tabela 2 - Valores médios do número de folhas (NF), comprimento das folhas (CF), área foliar (AF), massas das matérias fresca (MF) e seca (MS) de rúcula, em função da adubação com farinha de ossos calcinada (FOC), tratada com diferentes concentrações de ácido acético (AA) e da adubação com superfosfato simples (SFS).

\begin{tabular}{lccccc}
\hline Tratamento & NF & $\mathbf{C F}(\mathbf{c m})$ & $\left.\mathbf{A F} \mathbf{( c m}^{2}\right)$ & $\mathbf{M F}(\mathbf{m g})$ & $\mathbf{M S}(\mathbf{m g})$ \\
\hline FOC 0\% AA & $5,50 \mathrm{~b}$ & $7,26 \mathrm{~b}$ & $53,42 \mathrm{~b}$ & $1,36 \mathrm{~b}$ & $0,10 \mathrm{~b}$ \\
\hline FOC 15\% AA & $5,12 \mathrm{~b}$ & $8,01 \mathrm{~b}$ & $93,88 \mathrm{~b}$ & $1,89 \mathrm{~b}$ & $0,21 \mathrm{~b}$ \\
\hline FOC 30\% AA & $6,12 \mathrm{~b}$ & $10,42 \mathrm{~b}$ & $171,07 \mathrm{~b}$ & $3,63 \mathrm{~b}$ & $0,31 \mathrm{~b}$ \\
\hline FOC 60\% AA & $8,75 \mathrm{~b}$ & $11,90 \mathrm{~b}$ & $323,43 \mathrm{~b}$ & $9,41 \mathrm{~b}$ & $0,95 \mathrm{~b}$ \\
\hline SFS & $13,50 \mathrm{a}$ & $22,37 \mathrm{a}$ & $897,76 \mathrm{a}$ & $27,15 \mathrm{a}$ & $2,95 \mathrm{a}$ \\
\hline CV (\%) & 29,63 & 23,82 & 43,36 & 46,63 & 47,88 \\
\hline
\end{tabular}

Médias seguidas pelas mesmas letras, nas mesmas colunas, não diferem, entre si, pelo teste Dunnett, a 5\% de probabilidade

$\mathrm{O}$ número de folhas apresentou crescimento linear em relação às doses de AA aplicadas à FOC (Figura 1, p-valor=0,07), o que já era esperado, pois, de acordo com Taiz e Zeiger (2004), o fósforo é um dos micronutrientes responsáveis pelo número de folhas nas plantas.

Figura 1 - Número médio de folhas de rúcula em função da concentração de solução de ácido acético aplicado na farinha de ossos calcinada

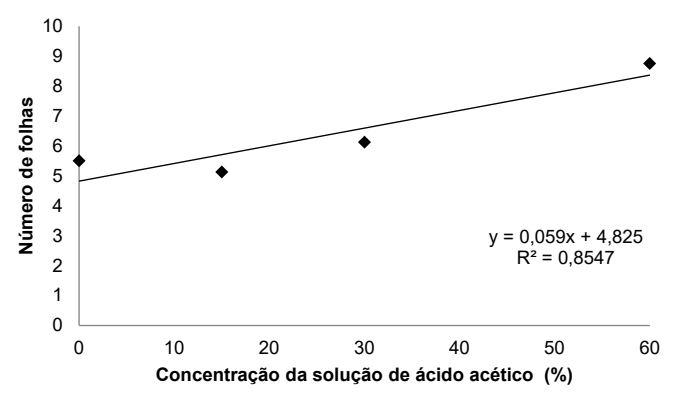

Para as variáveis comprimento de folha (Figura 2, $\mathrm{p}$-valor=0,03) e área foliar (Figura 3, p-valor=0,01), ocorreu crescimento linear de 63,8\% e $505,3 \%$ respectivamente, entre os tratamentos com menor e maior concentrações de AA, podendo ser considerada uma fonte de fosfato de baixa a média reatividade. Nesse sentido, o uso associado de farinha de ossos com outra adubação de alta reatividade de fosfato é vantajoso, visto que, segundo 
Novais (1999), a aplicação de fosfatos de baixa reatividade pode promover uma maior eficiência da adubação fosfatada, quando bem manejados com fosfatos de maior reatividade.

Figura 2 - Média do comprimento das folhas de rúcula em função da concentração da solução de ácido acético aplicado na farinha de ossos calcinada

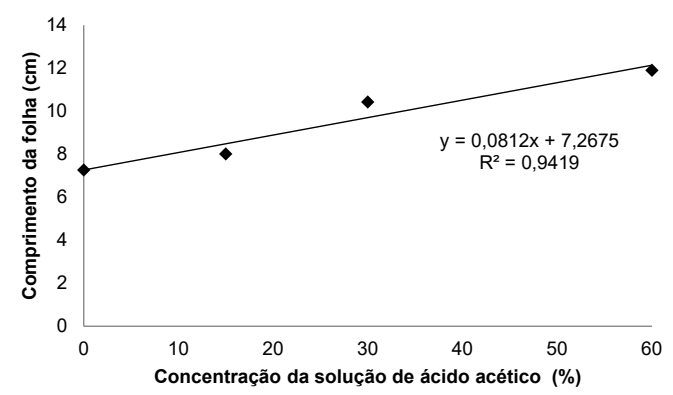

Figura 3 - Média da área foliar da rúcula em função da concentração da solução de ácido acético aplicado na farinha de ossos calcinada

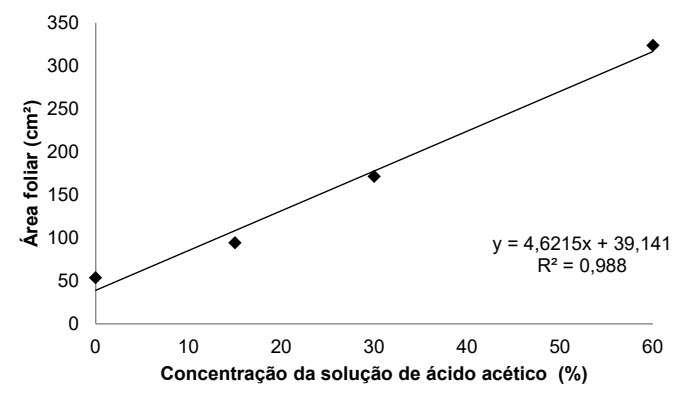

Também se pode observar incremento de $777 \%$ para massa da matéria fresca (Figura 4, p-valor=0,02) e 591,4\% para massa da matéria seca (Figura 5, p-valor=0,04), no tratamento com concentração de $60 \%$ AA em relação à FOC sem tratamento acidificante, indicando que, na produção de rúcula, pode-se utilizar a FOC acidificada para um maior crescimento das plantas. 
Figura 4 - Média da massa da matéria fresca da rúcula em função da concentração da solução de ácido acético aplicado na farinha de ossos calcinada

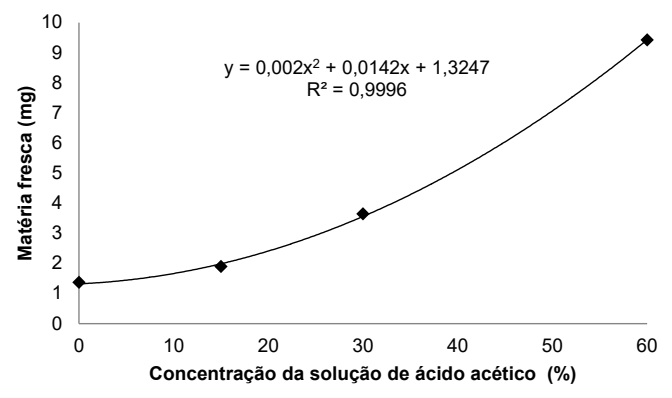

Figura 5 - Média da massa da matéria seca da rúcula em função da concentração da solução de ácido acético aplicado na farinha de ossos calcinada

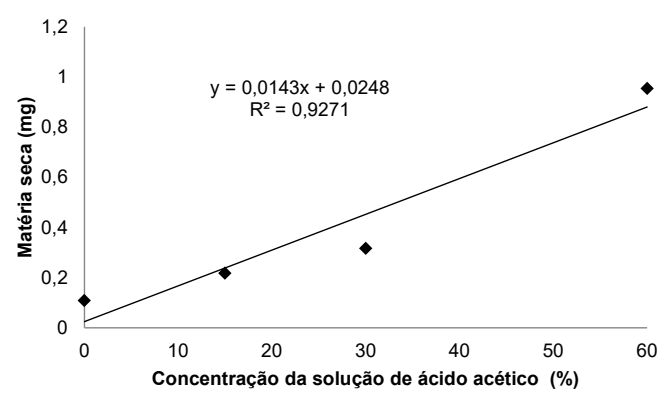

O baixo crescimento nas concentrações de $15 \%$ e $30 \%$ AA, possivelmente, foi resultante da baixa liberação do fósforo, ao ser adotado o intervalo de 15 dias entre a adubação e a semeadura da rúcula, ou seja, as condições de adubação não foram condizentes com a velocidade e quantidade necessárias para o crescimento da planta. No entanto, de acordo com Drescher et al. (2012), a utilização de fontes menos reativas, como o fosfato natural reativo de Arad e farinha de ossos, apresenta o benefício de um efeito residual prolongado para cultivos agrícolas.

Em plantas tratadas com FOC à $0 \% \mathrm{AA}$, o crescimento foi lento, com diminuição no porte; inicialmente, as folhas mais velhas adquiriram coloração arroxeada que progrediu para as folhas jovens. Posteriormente, essa coloração arroxeada evoluiu para necrose, começando nas pontas das folhas e seguindo em direção à base (Figura 6A e 6B). Esse processo também foi observado em plantas de milho por Ferreira (2012), 
que associou os sintomas à deficiência de fósforo $(\mathrm{P})$. De acordo com Taiz e Zeiger (2004), na planta, o fósforo apresenta alta mobilidade, transferindo-se rapidamente de tecidos mais velhos para regiões de meristemas ativos. Assim, em algumas plantas, as folhas podem apresentar manchas necróticas como sintomas de malformação.

Figura 6 - A e B) Deficiência de fósforo na rúcula adubada com farinha de ossos calcinada sem acidificação. C) Rúculas adultas fertilizadas com farinha de ossos calcinada em diferentes concentrações de soluções de ácido acético (AA) e com superfosfato simples (SFS).

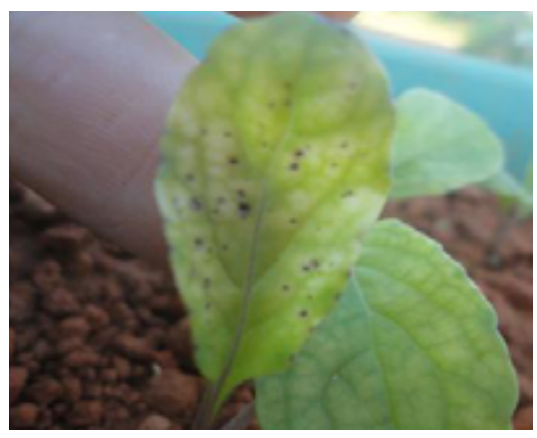

A

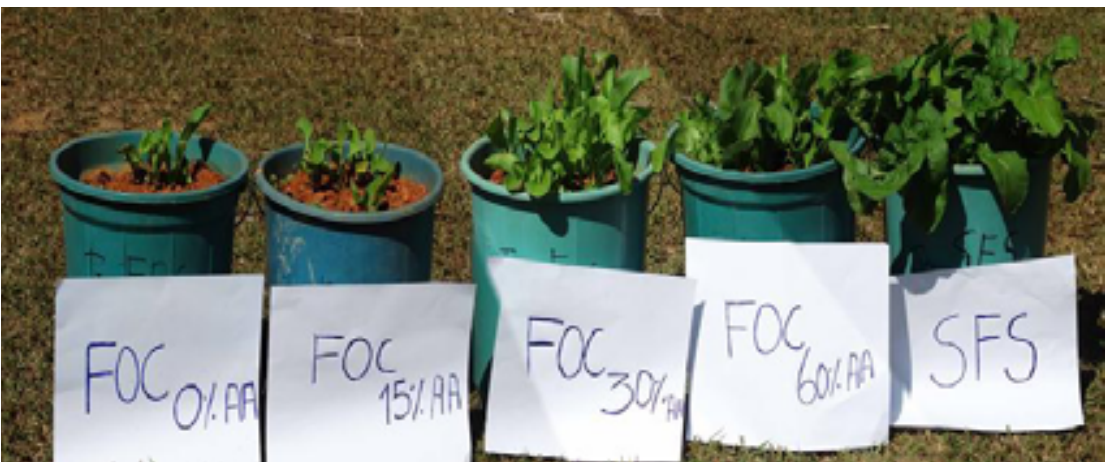

$\mathrm{C}$

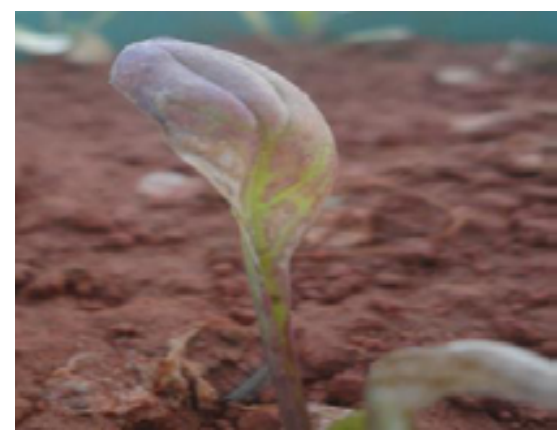

$\mathrm{B}$

$\mathrm{O}$ crescimento da rúcula, observado na Figura $6 \mathrm{C}$, demonstra o efeito positivo dos tratamentos com ácido acético, em que a concentração de $60 \%$ AA proporcionou maior crescimento da rúcula (Figura 5), o que pode ser atribuído à maior quantidade de fósforo disponível, à medida que se aumentou a concentração de ácido acético aplicado à FOC. 
Considerando que a FOC possui outras substâncias que podem ter influenciado nos resultados obtidos, novos estudos devem ser conduzidos, avaliando as concentrações de nutrientes foliares. Ressalta-se, ainda, a importância de se avaliar o desempenho de maiores concentrações de AA (>60\%) para alcançar o máximo de aproveitamento dos nutrientes contidos na FOC. Para resultados conclusivos, deve-se também observar os efeitos residuais da farinha de ossos calcinada acidificada, no cultivo de plantas em condições de campo e ao longo do tempo.

Desse modo, para uma melhor compreensão do comportamento da farinha de ossos aplicada ao solo, como fertilizante e como suprimento de fósforo, torna-se imprescindível o conhecimento da velocidade de solubilização desse material no solo, juntamente com outras características, como o diâmetro das partículas em relação ao tempo de exposição ao processo de acidificação.

\section{Considerações finais}

O tratamento crescente com ácido acético sobre a farinha de ossos calcinada apresentou efeito positivo e linear sobre a rúcula, avaliado pelas massas de matérias seca e fresca, área foliar, número e comprimento da folha. Embora esse método avaliativo tenha demonstrado eficiência e potencial de uso, sugere-se, ainda, estudos para analisar a liberação dos nutrientes da FOC acidificada em relação à velocidade de absorção das espécies de interesse da dinâmica do fósforo no solo, bem como da relação custo/benefício dessa técnica.

\section{Referências}

BALBINO, T. G. M. Farinha de ossos calcinada com fonte de fósforo para o capim Tifton (Cynodon dactilon L.). 2011. 30f. Monografia (Graduação em Agronomia) - Universidade Federal de Rondônia, Rolim de Moura, 2011.

BELLAVER, C. Resíduos industriais (farinhas, óleos e sebos): onde colocá-los frente às restrições de mercado? In: Seminário Internacional da Industrialização da Carne. 226p. 2002. Disponível em: <http://www.agencia.cnptia.embrapa.br/Repositorio/residuos_industriais_farinhas_oleos_sebos_onde_colocar_frente_restricoes_mercado_000fyrf1p7802wx5ok0pvo4k3nyih4dz.pdf>. Acesso em: 3 jul. 2014. 
CAVALLARO JÚNIOR. M. L. Fertilizantes orgânicos e minerais como fontes de N e de $\mathbf{P}$ para produção de rúcula e tomate. 2006. 39 f. Dissertação (Mestrado em Tecnologia da Produção Agrícola) - Instituto Agronômico de Campinas, Campinas - SP, 2006.

DRESCHER,A.H.; CAIONE, G.; RODRIGUES,M.; PASUCH,B.D.; FERNANDES, F. M.; CAMPOS, C. N. S. Atributos químicos do solo cultivado com cana-de-açúcar sob efeito residual de fontes de fósforo. Tecnologia \& Ciência Agropecuária, v.6, n.2, p.35-40, 2012.

EVALD, A. Densidade radicular do capim mombaça irrigado e submetido a farinha de ossos calcinada. Rolim de Moura, RO. 2014. 47 f. Monografia (Graduação em Agronomia) - Universidade Federal de Rondônia, Rolim de Moura.

FERREIRA, M. M. M. Sintomas de deficiência de macro e micronutrientes de plantas de milho híbrido BRS $1010^{1}$. Nota técnica. Revista Agro@ambiente Online, v.6, n.1, p.74-83, 2012.

FERREIRA, O. G. L.; ROSSI, F. D.; ANDRIGHETTO, C. DDA: Determinador Digital de Áreas - Software para determinação de área foliar, índice de área foliar e área de olho de lombo. Versão 1.2. Santo Augusto: IFFarroupilha. 2008.

FREITAS, G. A. Resíduo de efluente de frigorífico bovino como fertilizante alternativo para a produção de rúcula. Pesquisa Aplicada \& Agrotecnologia, v.3, n.2, p39-40. 2010.

KIEHL, E. J. Fertilizantes Orgânicos. Editora Agronômica Ceres: Piracicaba, 1985.

NOVAIS, R. F. Utilização de fosfatos Naturais de baixa reatividade. In: RIBEIRO, A. C.; GUIMARÃES, P. T. G.; ALVAREZ, V. V. H. Recomendações para o uso de corretivos e fertilizantes em Minas Gerais. 5a Aproximação. Comissão de Fertilizantes do solo do Estado de Minas Gerais (CFSEMG): Viçosa, 1999. p. 59-61.

PACHECO, J. W. F. Graxarias. Processamento de materiais de abatedouros e frigoríficos bovinos e suínos. Guia técnico ambiental de graxarias. SÉRIE P+L. CETESB: São Paulo, 2006.

PEEL, M. C.; FINLAYSON, B. L.; McMAHON, T. A. Updated world map of the Köppen-Geiger climate classification. Hydrology and Earth System Sciences, v.11, p.16331644, 2007. Disponível em: <http://www.hydrol-earth-syst-sci.net/11/1633/2007/hess-111633-2007.pdf>. Acesso em: 2 jul. 2013.

R CORE TEAM. R: A language and environment for statistical computing. R Foundation for Statistical Computing, Vienna, Austria, 2015. Disponível em: <https://www.R-project.org/>. Acesso em: 1 out. 2015.

ROSCOE, R. Aproveitamento Agrícola de Resíduos de Frigorífico com Fertilizante Orgânico Sólido. Boletim de Pesquisa e Desenvolvimento. Embrapa Agropecuária Oeste: Dourados, MS, 2010.30p. (Informe técnico). 
SANTOS, E. A.; KLIEMANN, H. J. Disponibilidade de fósforo de fosfatos naturais em solo de Cerrado e sua avaliação por extratores químicos. Pesquisa Agropecuária Tropical, v.35, n.3, p.139-146, 2005.

SATELIS, H. G. Resposta da alface submetida a adubação orgânica com farinha de carne e osso. Rolim de Moura, RO. 2010. 23 f. Monografia (Graduação em Agronomia) Universidade Federal de Rondônia, Rolim de Moura, 2010.

TAIZ, L.; ZEIGER, E. Fisiologia vegetal. Porto Alegre: Artmed, 2004. 



\title{
12. POTENCIALIDADES DO USO DA FARINHA DE OSSOS
}

\author{
Adjalma Campos de França Neto \\ Elvino Ferreira \\ Jerônimo Vieiria Dantas Filho \\ Klaus Casari Saturnino \\ Thais Rabelo dos Santos
}

Na Europa, a farinha de carne e ossos não está sendo mais utilizada para alimentação de ruminantes desde 2000, em decorrência de sua possível ligação com o príon, agente transmissor da encefalopatia espongiforme bovina, nos anos 90 (CONESA, FULLANA, FONT, 2003; MONDINI et al., 2008). Em função de sua composição (Tabela 1), a farinha de ossos pode ser empregada de forma alimentar ou não, devido a restrições legais (GARCIA, ROSENTRATER, 2008). Para o caso de contaminação, alguns métodos para sua inativação têm sido propostos na Europa, como aquele que usa altas pressões e temperatura (>0,3 $\mathrm{MPa}, 133^{\circ} \mathrm{C} 20$ / minutos), mas somente o uso de hipoclorito de sódio concentrado parece possibilitar a inativação total do prion (CONESA, FULLANA, FONT, 2005) ou mesmo a incineração acima de $800^{\circ} \mathrm{C}$ (DEYDIER, GUILET, SHARROCK, 2003).

Com a finalidade de controlar e mesmo erradicar o problema da "vaca louca” (bovine spongiform encephalopathy - BSE), atualmente é adotado na Europa um sistema de classificação em três categorias para esses resíduos. A primeira, representada por material de alto risco, inclui carcaça de animais suspeitos ou mesmo de zoológicos e pets confirmados para BSE. A segunda refere-se a animais doentes ou que morrem nas criações. A terceira envolve animais de interesse econômico, considerados de baixo risco para BSE. Os materiais das duas primeiras categorias são obrigatoriamente incinerados (DEYDIER et al., 2007), e os de segunda e terceira, usados como fertilizantes (SPANGBERG et al., 2011). 
A quantidade gerada desses resíduos é importante. $\mathrm{O}$ total de farinha de carne e ossos produzidos na Europa excede a 3.500.000 toneladas por ano (COUTAND et al., 2008). Na França, por exemplo, 850.000 toneladas de farinha de carne e ossos são produzidas a cada ano, e somente $45 \%$ são calcinados em indústrias de cimento. Os 55\% restantes são armazenados para posterior destruição. $\mathrm{Na}$ calcinação, a produção de cinzas representa um quantitativo de até 30\% do peso (DEYDIER, GUILET, SHARROCK, 2003). Há interesse pela indústria farmacêutica na extração de lipídeos, contudo, os equipamentos necessários e a sofisticação do processo a torna de elevado custo, gerando no mercado a presença da farinha de carne e ossos não desengordurada (MONDINI et al., 2008).

Em termos térmicos, a farinha de carne e ossos pode ser considerada um bom combustível (valor calorífico líquido de $17.000 \mathrm{~kJ} \mathrm{~kg}^{-1}$, similar ao da madeira) e seu uso em fornos em geral, fornos de cimento e caldeiras leva à substituição de combustíveis fósseis, com interesse ambiental e vantagem econômica (CONESA, FULLANA, FONT, 2003, 2005; GARCIA, ROSENTRATER, 2008). Sua transformação por pirólise (500 $\mathrm{C} ; 15^{\circ} \mathrm{C} /$ min a vácuo) gera produtos de alto valor energético como gás $(12,9 \mathrm{MJ}$ $\left.\mathrm{kg}^{-1}\right)$ e óleo $\left(34,2 \mathrm{MJ} \mathrm{kg}^{-1}\right)$, além de um resíduo sólido rico em sais minerais e uma fase aquosa rica em produtos orgânicos (AYLLÓN et al., 2006).

A incineração da farinha de carne e ossos é um caminho para se resolver a situação jurídica relativa ao problema da encefalopatia espongiforme bovina, apesar das preocupações quanto à produção de dioxinas e furanos (CONESA, FULLANA, FONT, 2005; MONDINI et al., 2008), mesmo que em menores quantidades, quando comparado com a incineração do lodo de esgoto (AYLLÓN et al., 2006). Quando se considera o processo de pirólise para o tratamento da farinha de carne e ossos, registram-se quantidades importantes de dioxinas e furanos formados (3000 a $9000 \mathrm{pg} \mathrm{g}^{-1}$ ), sendo superiores às observadas em incineradores industriais de lodo de esgoto $\left(270 \mathrm{pg} \mathrm{g}^{-1}\right)$ e incineradores de lixo municipal (200 a $1000 \mathrm{pg} \mathrm{g}^{-1}$ ). Apesar de que com a pirólise não se conta com a participação do oxigênio, a quantidade constitutiva presente na farinha de carne e ossos $(11,9 \%$ O) age como precursor de fenóis e ésteres que, 
teoricamente, poderiam produzir dioxinas e furanos. A quantidade de oxigênio necessária para produção de dioxinas é muito pequeno e, para essas substâncias, a máxima produção ocorre em temperaturas entre 700 a $800{ }^{\circ} \mathrm{C}$, mas se reduz de forma drástica em temperaturas maiores que $950{ }^{\circ} \mathrm{C}$ (CONESA, FULLANA, FONT, 2005). Cabe ressaltar que as dioxinas (polychlorinated-p-dibenzodioxins ou PCDD) e os furanos (polychlorinated-p-dibenzofurans ou PCDF), duas classes de compostos aromáticos tricíclicos que formam um grande número de congêneres, são altamente tóxicos, acumulam-se na cadeia alimentar associados a lipídeos e estão relacionados à incidência de câncer em várias partes do organismo (ASSUNCAO, J. V; PESQUERO, 1999).

A aplicação de farinha de ossos no solo (FCO ou FOC) é uma estratégia promissora para ciclagem de nutrientes e sustentabilidade de agroecossistemas. Para FOC, o estudo das questões de fixação de fosfato pelas argilas do solo, de seu poder corretivo, do carbono residual em função do nível de tratamento térmico aplicado, bem como de tratamentos ácidos para maior solubilização do fosfato, pode gerar tecnologias promissoras para as propriedades de cunho familiar, em regiões onde o sistema de comercialização de carnes não está totalmente desenvolvido (FERREIRA, 2014). No caso de farinha de carne e ossos, há necessidade de conhecimento de seu efeito quanto à dinâmica de sua mineralização e influência na microbiota, já que a FCO exerce papel fundamental na qualidade do solo. Por exemplo, seu alto conteúdo de lipídeos $(7,7 \%)$ pode inibir e mesmo causar mudanças no equilíbrio das populações de microrganismos do solo, apesar de registro de não ser verificado efeito depressivo. Quando utilizada como fertilizante orgânico, gera efeito positivo na disponibilidade de $\mathrm{N}$ do solo pela produção de amônio e nitrato, inibição da urease, aumento da atividade da fosfatase e de microrganismos (MONDINI et al., 2008).

Em relação ao metabolismo do solo, registra-se pico de evolução de C-CO $\mathrm{CO}_{2}$ entre 2 a 3 dias após sua aplicação no solo (200 e $400 \mathrm{~kg} \mathrm{ha}^{-1}$ de $\mathrm{N}$ ), com aumento de 10 a 16\%, que podem ser comparados aos registrados com o manejo de esterco de galinha (16\%) e dejeto de suínos (19\%) 
(MONDINI et al., 2008). Certamente, a qualidade dos resíduos de C estão presentes nessa dinâmica (aminoácidos; monossacarídeos, ácidos orgânicos), induzindo, em função da disponibilidade da fonte, os mecanismos de imobilização e mineralização, e mesmo por envolver o compartimento de $\mathrm{N}$ orgânico do solo para o estabelecimento do equilíbrio da relação $\mathrm{C}: \mathrm{N}$ da microbiota, que é semelhante a 8 (MONDINI et al., 2008).

Outro questionamento diz respeito a sua composição no tocante à presença de metais pesados (Tabela 1), com a preocupação de que seu emprego não cause danos em relação à cadeia trófica. Nesse contexto, o uso da farinha de ossos calcinada não representa aparente problema quanto a Zinco $(\mathrm{Zn})$, Níquel $(\mathrm{Ni})$, Cobre $(\mathrm{Cu})$ e Chumbo $(\mathrm{Pb})$, em observância, por exemplo, à concentração crítica estabelecida para solos do Reino Unido (Zn: 70-400; Ni: 100; Cu: 60-125 e Pb: 100-400 $\mu$ g de Metal por grama de solo) (HODSON, et al., 2001). No entanto, o uso, por muitos anos, de adubo fosfatado derivado de rochas pode representar problema de Cádmio (Cd) em solos agricultáveis e para as culturas (GARCIA, ROSENTRATER, 2008), havendo também as implicações sobre o consumo de energia para sua produção, emissão de gases de efeito estufa, entre outros. Na Suécia, por exemplo, estudo avaliando o emprego da farinha de carne e ossos, em relação a fertilizante industrial nitrogenado, registrou redução da emissão de gases de efeito estufa, redução de gases acidificantes e do uso de energia não renovável. O fluxo de cádmio no solo permaneceu aproximadamente o mesmo, mas registrou-se aumento no uso de energia total e também aumento do efeito potencialmente eutrofizante para águas (SPANGBERG et al., 2011). Comentam os autores, ainda, sobre o desafio da fertilização de solos para fazendas de produção orgânica, em especial, aquelas sem o acesso a esterco animal, da recuperação de nutrientes pelas plantas e sobre a dependência de infraestrutura e as prioridades ambientais da sociedade.

Em termos de remediação de áreas contaminadas por metais pesados, o emprego da farinha de ossos se torna promissor. O elevado teor e a baixa solubilidade do fosfato possibilita a adsorção do metal, retendo-o in sito em solos contaminados de forma a prevenir a contaminação 
de águas. Muitos experimentos têm registrado sucesso no uso de hidroxiapatitas sintéticas na remediação de solos contaminados com chumbo $(\mathrm{Pb})$, devido à formação de piromorfita $\left[\mathrm{Pb}_{5}\left(\mathrm{PO}_{4}\right)_{3} \mathrm{OH}\right]$. Os fosfatos dos ossos moídos, por apresentarem estrutura cristalina pobre e também semelhante às hidroxiapatitas sintéticas, podem ser destinados à remediação de solos contaminados com custo comercial 25\% menor. Em estudos de colunas de lixiviação, registra-se redução significativa de zinco $(\mathrm{Zn})$, níquel $(\mathrm{Ni})$, cobre $(\mathrm{Cu})$, ferro $(\mathrm{Fe})$ e alumínio $(\mathrm{Al})$, como também chumbo $(\mathrm{Pb})$, arsênio (As) e urânio (U), em função da formação de fosfatos de baixíssima solubilidade, sendo esses compostos estáveis em variadas condições de Eh e $\mathrm{pH}$, reduzindo, portanto, sua biodisponibilidade (HODSON et al., 2001; SNEDDON et al., 2006). Devido, em sua constituição, também haver cálcio $(\mathrm{Ca})$, há, de maneira pontual, elevação do $\mathrm{pH}$, o qual promove a sorção de metais com o fosfato da farinha de ossos no solo. Em especial para Níquel, sua imobilização aumenta com o decréscimo do tamanho da partícula de farinha de ossos aplicada. Em contrapartida, é possível que a adição de farinha de ossos possa aumentar a biodisponibilidade de cobre por sua capacidade em formar complexos organo- $\mathrm{Cu}$ a um $\mathrm{pH}$ próximo da neutralidade, na presença de compostos orgânicos (HODSON et al., 2001), ou mesmo apresentar dissolução limitada de apatita a pH elevado, o que iria limitar a formação de piromorfita (SNEDDON et al., 2008).

Para cádmio e zinco, registra-se a capacidade de troca catiônica estimada em 0,17 e 0,24 $\mathrm{mmol} \mathrm{g}^{-1}$ para $\mathrm{Cd}$ e $\mathrm{Zn}$, respectivamente, com o uso de farinha de ossos carbonizada. Na condição de solo, o intemperismo pode alterar as relações de sorção e substituição no complexo de trocas, excedendo sua capacidade adsortiva e promovendo o retorno parcial de metais biodisponíveis ao solo (SNEDDON et al., 2006), e mesmo comprometer a efetividade da sorção entre o metal e o fosfato, como método de remediação na contaminação por metais, em solos ácidos (SNEDDON et al., 2008).

Em águas ou em solos contaminados com chumbo $(\mathrm{Pb})$, que se acumula na cadeia alimentar causando desordens fisiológicas, neurológicas e morte, a efetividade do uso da farinha de ossos na imobilização do 
metal está relacionada à temperatura de combustão, processo de lavagem e ao tamanho das partículas da farinha de ossos calcinada. Há, para essa condição, por exemplo, superfície específica de $11 \mathrm{~m}^{2} \mathrm{~g}^{-1}$ com $99 \%$ das partículas menores que $0,25 \mathrm{~mm}$, quando se gera a capacidade de imobilização de $250 \mathrm{mg}$ de chumbo por grama de FOC. Nesse processo, há mecanismos de complexação de superfície, dissolução seguida por precipitação (hidroxiapatita- $\mathrm{Pb}$ ) e lenta difusão de chumbo com substituição de $\mathrm{Ca}$, criando camadas. Pode-se observar o $\mathrm{pH}$ final com valores de $\mathrm{pH}$ 7,0 ou 4,9 para concentrações iniciais de 500 e 1500 ppm de chumbo, respectivamente. Os eventos de complexação e dissolução ocorrem rapidamente, com capacidade estimada para adsorver de chumbo de $275 \mathrm{mg}$ de $\mathrm{Pb}$ por $\mathrm{g}$ de cinzas de ossos em menos de $3 \mathrm{~h}$. Para ser atingida a capacidade total de imobilização, seriam necessários mais do que 10 dias (DEYDIER, GUILET, SHARROCK, 2003). Cabe ressaltar que solos alcalinos não são efetivos para serem tratados com FO, no sentido de imobilização de metais pesados, o que pode ser bem sucedido para solos com pH abaixo da neutralidade (SNEDDON et al., 2008).

Em avaliação por modelos biológicos, registra-se que, para o caso de solo, com níveis de $\mathrm{Pb}$ de 50,100, 2000 e $10.000 \mathrm{mg} \mathrm{kg}{ }^{-1}$, com aporte de farinha de ossos calcinada $\left(35,3 \mathrm{~g} \mathrm{~kg}^{-1}\right.$ de solo), não foram observados efeitos tóxicos em tabaco (Nicotiana tabaccum var. xanthi Dulieu). Para o caso de águas, a adição de $100 \mathrm{mg} \mathrm{L^{-1 }}$ de FOC foi capaz de neutralizar os efeitos tóxicos do $\mathrm{Pb}$ em concentrações de até $10 \mathrm{ppm}$ para girinos da espécie Xenopus laevis (DEYDIER et al., 2007). Comentam os autores que os efeitos tóxicos e genotóxicos do chumbo aparecem em concentrações menores que $1 \mathrm{mg} \mathrm{L}^{-1}$ de $\mathrm{Pb}(1 \mathrm{ppm})$.

Em termos de importância ambiental, também há estudos relacionados ao uso da farinha de ossos calcinada para a retenção de enxofre (gás), comparando-o com a dolomita sintética, a fim de se evitar problemas relacionados a chuvas ácidas, aquecimento global e corrosão de equipamentos. A capacidade de retenção de enxofre $\left(\mathrm{H}_{2} \mathrm{~S}\right)$ foi significativamente diferente quanto ao uso de farinha de ossos carbonizada $(0,139 \mathrm{~g}$ $\left.\mathrm{g}^{-1}\right)$, calcinada $\left(0,221 \mathrm{~g} \mathrm{~g}^{-1}\right)$ e dolomita sintética $\left(0,360 \mathrm{~g} \mathrm{~g}^{-1}\right)$, sendo esse 
material considerado não adequado para remoção de enxofre em processo de limpeza gasosa. Comentam ainda os autores que o teor de metais nos sólidos pode estar relacionado com tal comportamento (CASCAROSA, et al., 2012).

Ao se considerar as restrições legais para o uso da farinha de carne e ossos na alimentação de ruminantes, vislumbram-se muitas alternativas de interesse energético e ambiental. Uma importante alternativa seria seu emprego como fertilizante, em função de sua composição (Tabela 1), principalmente com o objetivo educacional de serem promovidas a reciclagem e nutrientes, em agroecossistemas orgânicos, de cunho familiar, no sentido de se atingir não somente uma grande área, mas também um grande número de pessoas. 


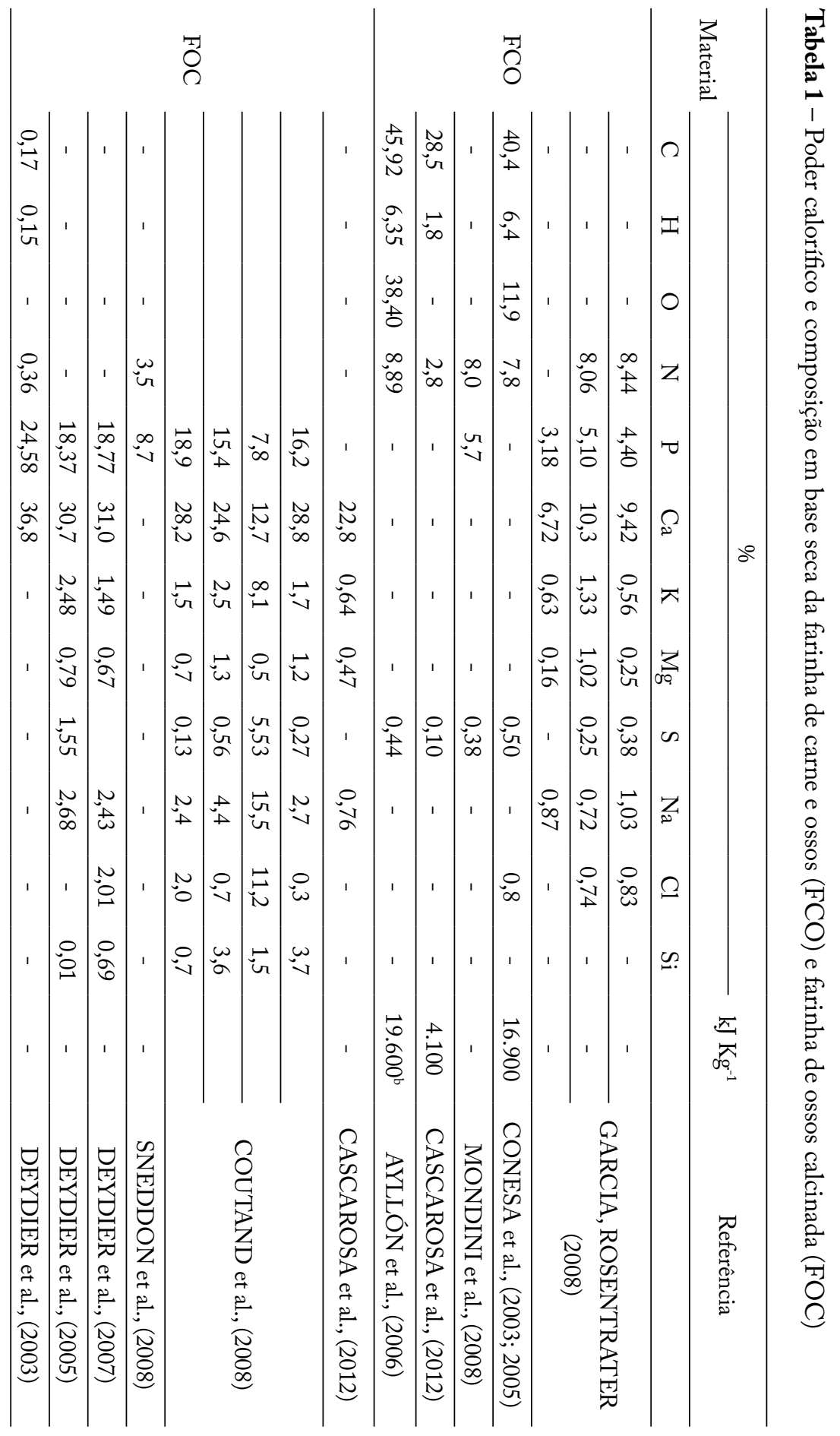




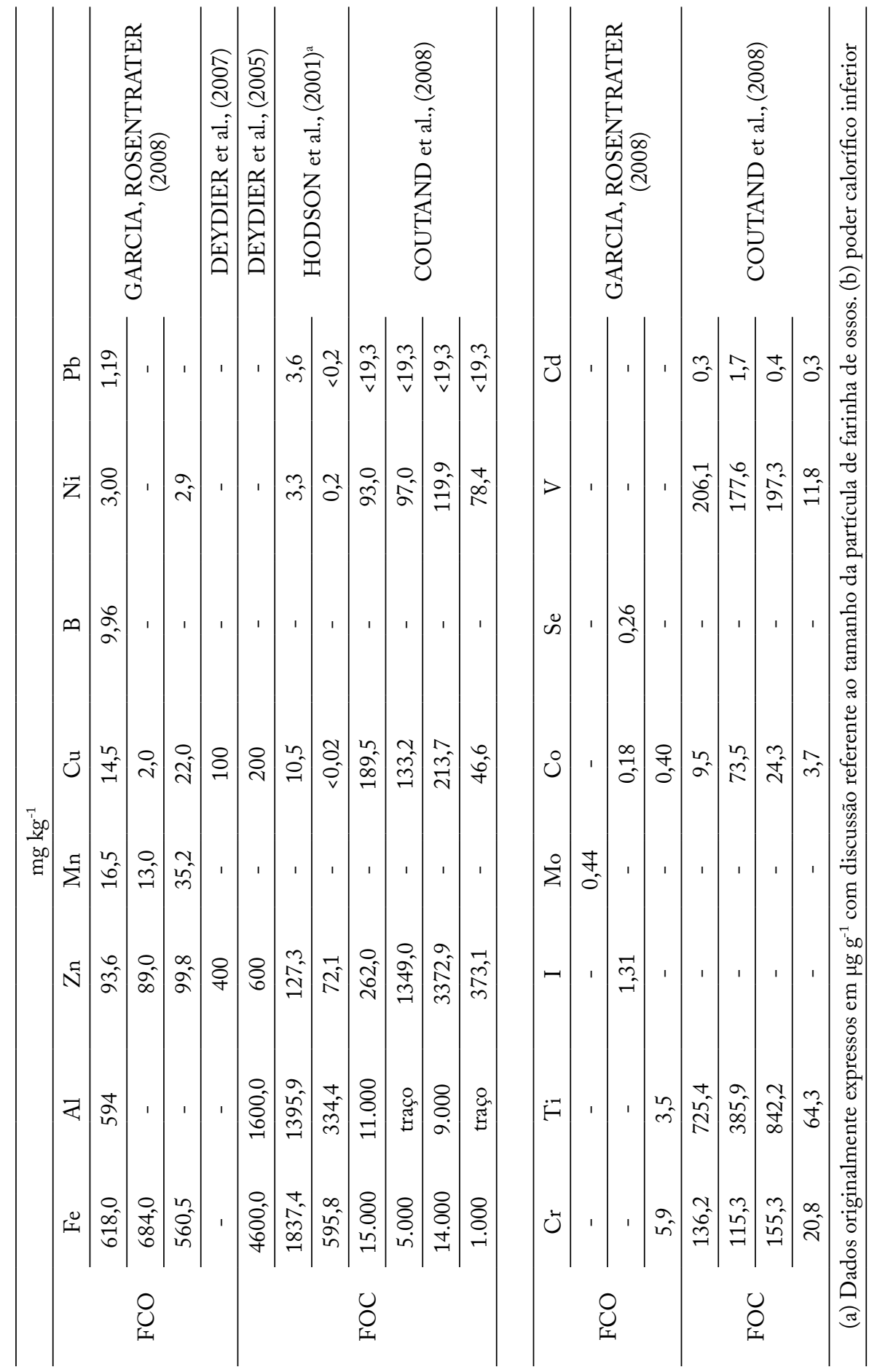




\section{Referências}

ASSUNCAO, J. V; PESQUERO, C. R. Dioxinas e furanos: origens e riscos. Revista de Saúde Pública, São Paulo, v. 33, n. 5, p. 523-530, 1999.

AYLLON, M.; AZNAR, M.; SÁNCHES, J. L.; GEA, G.; ARAUJO, J. Influence of temperature and heating rate on the fixed bed pyrolysis of meat and bone meal. Chemical Engineering Journal, 21, . p. 85-96, 2006.

CASCAROSA, E.; ZARATE, M. C. O.; SANCHEZ, J. L.; GEA, G.; ARAUJO, J. Sulphur removal using char and ash from meat and bone meal pyrolysis. Biomass and Bioenergy, 40, 190-193, 2012.

CONESA, J. A.; FULLANA, A.; FONT, R. Dioxin production during the termal treatment of meat and bone meal residues. Chemosphere, 59, p. 85-9, 2005.

CONESA, J. A.; FULLANA, A.; FONT, R. Thermal decomposition of meat and bone meal. Journal of Analytical and Applied Pyrolysis, v. 70, p. 619-630, 2003.

DEYDIER, E.; GUILET, R.; SHARROCK, P. Beneficial use of meat bone meal combustion residue: "an efficient low cost material to remove lead from aqueous effluent". Journal of Hazardous Materials, v.101, p. 55-64, 2003.

DEYDIER, E.; GUILET, R.; SARDA, S.; SHARROCK, P. Physical and chemical characterization of crude meat and bone meal combustion residue: "Waste or raw material?" Journal of Hazardous Materials, v.121, p. 141-148, 2005.

DEYDIER, E.; GUILET, R.; CRENS, S.; PEREAS, V.; MOUCHET, F.; GAUTHIER, L. Evaluation of meal and bone meal combustion residue as lead immobilization material for in situ remediation of polluted aqueous solutions and soils: "Chemical and ecotoxicological studies”. Journal of Hazardous Materials, v. 146, p. 227-236, 2007.

FERREIRA, E. Utilização de resíduos na agropecuária: Farinha de ossos calcinada. In: WADT et al.(Ed.). Manejo dos solos e a sustentabilidade da produção agrícola na Amazônia Ocidental. cap.5, p. 75-86. REUNIÃO DE CIÊNCIA DO SOLO NA AMAZÔNIA OCIDENTAL, II, Anais... Porto Velho: Núcleo Regional Amazônia Ocidental da Sociedade Brasileira de Ciência do Solo. 2014.286p.

HODSON, M. E.; VALSAMI-JONES, E.; COTTER-HOLLEWS, J. D.; DUBBIN, W. E.; KEMP, A. J.; THORNTON, I.; WARREN, A. Effect of bone meal (Calcium phosphate) amendments on metal release from contaminated soils - a leaching column study. Environmental Pollution, v.112, p. 233-243. 2001.

MONDINI, C.; CAYUELA, M. L.; SINICCO, T.; SANCHEZ-MONEDERO, M. A.; BERTOLONE, E.; BARDI, L. Soil application of meal and boné meal. Short-term effects on mineralization dynamics and soil biochemical and microbiological properties. Soil Biology \& Biochemistry, v. 40, p. 462-474, 2008. 
SNEDDON, J. K.; ORUEETXEBARRIA, M.; HODSON, M. E.; SCHOFIELD, P. F.; VALSAMI-JONES, E. Use of bone meal amendments to immobilize $\mathrm{Pb}, \mathrm{Zn}$ and $\mathrm{Cd}$ in soil: A leaching column study. Environmental Pollution, v. 144, p. 816-825, 2006.

SNEDDON, J. K.; ORUEETXEBARRIA, M.; HODSON, M. E.; SCHOFIELD, P. F.; VALSAMI-JONES, E. Field trial using bone meal amendments to remediate mine waste derived soil contaminated with zinc, lead and cadmium. Applied Geochemistry, v. 23, p. 2414-2424, 2008.

SPANGBERG, J.; HANSSON, P. A.; TIDAKER, P.; JONSSON, H. Environmental impact of meat fertilizer vs chemical fertilizer. Resources, Conservation and Recycling, v. 55, p. 1078-1086, 2011. 



\section{SOBRE OS AUTORES}

\section{Acácio Bezerra de Mira}

Professor de Agronomia do Instituto Federal de Educação, Ciência e Tecnologia do Acre. Estudante de doutorado em Solos e Nutrição de Plantas pela ESALQ/USP. Mestre em Solos e Nutrição de Plantas pela ESALQ/ USP (2016). Engenheiro agrônomo graduado pela Universidade Federal de Rondônia (2014). Bolsista de iniciação científica por três anos, desenvolvendo pesquisas em fertilidade do solo e nutrição de plantas, fitotecnia e botânica. Bolsista do programa TOP Espanha do Banco Santander junto à Universidade de Salamanca, Espanha (2013)

\section{Anderson Cristian Bergamin}

Possui graduação em Agronomia pela Universidade Federal de Rondônia - UNIR (2007), Mestrado (2009) e Doutorado (2012) em Agronomia pela Universidade Federal da Grande Dourados - UFGD. Atualmente é professor Adjunto da Universidade Federal de Rondônia. Tem experiência na área de Agronomia, com ênfase em Gênese e Física do Solo, atuando principalmente com manejo do solo em sistemas sustentáveis de produção.

\section{Adjalma Campos de França Neto}

Graduado em Agronomia pela Universidade Federal de Viçosa, fez especialização em Manejo de irrigação pela Universidade Federal de Viçosa, mestrado em Meteorologia Agrícola pela Universidade Federal de Viçosa e doutorado em Irrigação e Drenagem pela Universidade Estadual Paulista Júlio de Mesquita Filho, Unesp. Atualmente é docente na Universidade Federal de Rondônia. Tem experiência na área de Agronomia, com ênfase em Irrigação e Agrometeorologia, atuando principalmente nos seguintes temas: evapotranspiração, hidráulica, manejo de irrigação e fertirrigação. 


\section{Alisson Vinicius Lorencetti Ferreira}

Graduado em Agronomia pela Universidade Federal de Rondônia, onde atuou como estagiário no Laboratório de Análise de Solo e como membro do Grupo de Estudo em Produção Animal e Aproveitamento de Resíduos (GEPAAR). Mestre em Ciências Ambientais pela Universidade Federal de Rondônia.

\section{Anna Frida Hatsue Modro}

Graduada em Ciências Biológicas pela Universidade do Estado de Mato Grosso (2004), mestre em Entomologia pela Universidade Federal de Viçosa (2006), especialista em Manejo Integrado de Pragas e Receituário Agronômico pela Universidade Federal de Lavras (2009), doutora em Ciências pela Universidade do Estado de São Paulo (2011). Docente no curso de Licenciatura em Educação Básica Intercultural da Universidade Federal de Rondônia, com experiência nas áreas de etnociência, apicultura, botânica, uso múltiplo de florestas, análise nutricional de produtos apícolas e melissopalinologia.

\section{Ariane Evald}

Graduada na área de ciências agrárias em Agronomia pela Universidade Federal de Rondônia (UNIR). Três anos de iniciação científica com o projeto Recuperação de pastagem na Amazônia Legal, aprovado pelo PIBIC/UNIR/CNPq. No ano de 2013, participou do Grupo de Estudos em Produção Animal e Aproveitamento de Resíduos com o projeto Densidade radicular do capim mombaça irrigado e fertilizado com farinha de ossos calcinada, o qual foi apresentado como trabalho de conclusão do curso no ano de 2014. Mestre em Agronomia, área de concentração Produção vegetal pela Universidade Federal de Roraima (UFRR), com estudos na linha de pesquisa em solos, estando inserida no grupo de pesquisa Solos de ecossistemas amazônicos, com ênfase em Roraima, da Universidade Federal de Roraima. Com dissertação intitulada: Qualidade do solo na cultura do arroz cultivado em várzea no estado de roraima. 


\section{Diego Boni}

Graduado em Engenharia Agronômica pela Universidade Federal de Rondônia, participou do Grupo de Estudos em Produção Animal e Aproveitamento de Resíduos, com interesse nas áreas relacionadas à fitotecnia, à fruticultura, ao melhoramento e recuperação de pastagens degradadas, e à cadeia produtiva do café. Tem experiência em Assistência Técnica e Extensão Rural.

\section{Douglas Borges Pichek}

Engenheiro Agrônomo formado na Universidade Federal de Rondônia - UNIR. Tem experiência na área de Agronomia. Participa de grupos de pesquisa em produção animal e aproveitamento de resíduos. Trabalha em linhas de pesquisa com aproveitamento de resíduos.

\section{Efraim Borges da Silva}

Possui Título de Técnico em Agropecuária Integrado ao Ensino Médio, Curso desenvolvido no Instituto Federal de Educação, Ciência e Tecnologia de Rondônia -IFRO - Campus Colorado do Oeste. Graduando no curso Bacharelado de Medicina Veterinária, pela Fundação Universidade Federal de Rondônia - UNIR- Campus Rolim de Moura. É membro do Grupo de Estudo em Produção Animal de Aproveitamento de Resíduos (GEPAAR). Integrante nos Projetos de Extensão: Água e desenvolvimento rural em Rolim de Moura - Amazônia Ocidental; e Capacitação de Produtores em Tecnologias na Criação de Bovinos de Leite em Rolim de Moura.

\section{Elvino Ferreira}

Possui graduação em Zootecnia, Especialização em Nutrição de Ruminantes, Mestrado em Agronomia e Doutorado em Agronomia pela Universidade Federal Rural do Rio de Janeiro. Atualmente desempenha atividade Docente, de Pesquisa e Extensão na Universidade Federal de Rondônia. Membro do Programa de Mestrado Acadêmico em Ciências Ambientais da Universidade Federal de Rondônia. É líder do Grupo de Estudo em Produção Animal de Aproveitamento de Resíduos (GEPAAR). Integra 
equipe multidisciplinar liderada pela Dra. Jill Caviglia-Harris (Salisbury University - USA), dedicada a analisar os impactos de políticas ambientais e dinâmicas de uso do solo no bem-estar das pessoas na Amazônia. Integra também a equipe do projeto CNH-L: Land-Climate-Water Feedbacks and Farmer Decision-Making in an Agricultural System, liderado pela Dra. Katrina Mullan (Montana University - USA).

\section{Emanuel Maia}

Agroecólogo, com formação em agronomia e doutorado em Fitotecnia (Produção Vegetal) pela Universidade Federal de Viçosa. Atualmente, professor Associado I na Universidade Federal de Rondônia, e atua como docente nos cursos de graduação em Agronomia e Engenharia Florestal em Rolim de Moura. Orientador de mestrado e doutorado do curso de pós-graduação em Desenvolvimento Regional e Meio Ambiente (www. pgdra.unir.br) e orientador do mestrado em Ciências Ambientais (www. pgca.unir.br). Líder do grupo de pesquisa em Produção Vegetal na Amazônia Ocidental. No campo de desenvolvimento científico e tecnológico, trabalha com foco em agroecologia, conservação da natureza e desenvolvimento regional nos seguintes temas: Sistemas Agroflorestais e Uso Múltiplo da Floresta.

\section{Fábio Régis de Souza}

Graduado em Agronomia pela Universidade Federal de Rondônia, Mestrado e Doutorado em Agronomia pela Universidade Federal da Grande Dourados. Tem experiência na área de Agronomia, com ênfase em Física do Solo e Manejo do solo, atuando principalmente nos temas Plantio direto, Corretivos e condicionadores do solo, Nutrição mineral de plantas, Fertilidade do solo, Relação solo-planta-atmosfera, Compactação do solo, Manejo de sistemas irrigados, Consórcio de culturas, Erosão.

\section{Isac Fogaça}

Graduado em Agronomia pela Universidade Federal de Rondônia. Mestrado em Ciências Ambientais pela Universidade Federal de Rondônia. 
Atualmente é extensionista rural de nível superior da Entidade Autárquica de Assistência Técnica e Extensão Rural do Estado de Rondônia. Atua na área de Agronomia com ênfase na Cafeicultura e bovinocultura de leite, atuando na produção de forragem e gerenciamento da atividade leiteira.

\section{Jairo Rafael Machado Dias}

Graduado em Engenharia Agronômica pela Universidade Federal de Rondônia, Mestre em Agronomia pela Universidade Federal do Acre e Doutor em Agronomia Tropical pela Universidade Federal do Amazonas. Atua principalmente nos temas Agronegócio, Reforma de Pastagem, Culturas anuais, Culturas perenes, Nutrição de plantas, Solos e Sistemas integrados de produção. Tem experiência em Segurança Pública, Direito Agrário e Ambiental. Atualmente coordena o Programa de Pós-Graduação em Agroecossistemas Amazônicos pela Universidade Federal de Rondônia.

\section{Jerônimo Vieria Dantas Filho}

Graduado em Engenharia de Pesca e Mestre em Ciências Ambientais pela Universidade Federal de Rondônia. Atuou na linha de pesquisa Interrelações nos sistemas de produção animal no bioma amazônico, com foco na adição da virginiamicina na ração para pirarucus de cultivo. Atuou como Membro do Grupo de Pesquisa em Tecnologias Agroambientais e como Diretor Financeiro da Associação de Engenheiros de Pesca do Estado de Rondônia. Atualmente é doutorando em Ciência Animal do Programa de Pós-Graduação em Sanidade e Produção Animal Sustentável na Universidade Federal do Acre, atuando na linha de pesquisa de Sistemas de Produção e Nutrição Animal: Piscicultura, com foco em análise de salmonelose no pescado comercializado nos estados do Acre e de Rondônia.

\section{Jhonnatan Wilker De Oliveira}

Graduando em Agronomia pela Universidade Federal de Rondônia. Trabalha em linhas de pesquisa com Fruticultura Tropical e Forragicultura. Atualmente é monitor de Mecanização Agrícola I e II. 


\section{João Batista Dias Damaceno}

Graduado em Engenharia Agronômica pela Universidade Federal de Rondônia, graduado em Engenharia de Segurança do Trabalho pela Faculdade de Rolim de Moura, Mestre em Agronomia - Agricultura no Trópico Úmido: Solos e Nutrição Mineral de Plantas, pelo Instituto Nacional de Pesquisas da Amazônia, e Doutorando em Agronomia Tropical (Produção Vegetal: Propriedade e Manejo de Solos Tropicais) pela Universidade Federal do Amazonas. Tem conhecimento em Produção Vegetal na área de cafeicultura e culturas anuais (Soja e Milho) e experiência nas áreas de Ciência do solo (Gênese, Fertilidade, Classificação e Manejo de Solos Amazônicos).

\section{Jucilene Cavali}

Professora Assistente da Universidade Federal de Rondônia. Engenheira Agrônoma, Doutora em Zootecnia pela Universidade Federal de Viçosa, em Produção Animal, atuando na área de Cadeia Produtiva da Carne com ênfase em Avaliação de Carcaça e Qualidade de Carne. Mestre em Zootecnia pela mesma instituição, na área de Forragicultura e Pastagens. Pesquisadora e Orientadora no Programa de Mestrado Acadêmico em Ciências Ambientais da UNIR/EMBRAPA e no Programa de Doutorado em Sanidade e Produção Animal Sustentável na Amazônia Ocidental PPGESPA/UFAC. Vice-líder do Grupo de Estudos em Produção Animal e Aproveitamento de Resíduos e do Grupo de Pesquisa em Tecnologias Agroambientais.

\section{Klaus Casaro Saturnino}

Graduado em Medicina Veterinária pela Universidade Estadual de Londrina, Mestrado e doutorado pela Universidade Federal do Mato Grosso do Sul, junto ao Programa de Pós Graduação em Ciência Animal. É docente da Universidade Federal de Jataí, junto ao Curso de Medicina Veterinária, ministrando as disciplinas de Patologia Geral e Patologia Especial Veterinária. Tem experiência nas áreas de Biologia Geral, com ênfase em Patologia, Anatomia e Diagnóstico por Imagem, com ênfase em Patologia 
Geral e Veterinária, incluindo Ictiopatologia. Atualmente exerce o cargo de coordenador do Laboratório de Patologia Veterinária da Universidade Federal de Jataí e atua como docente junto ao Programa de Residência em Medicina Veterinária desta mesma IES.

\section{Lindomar Alves De Souza}

Graduado em Gestão Ambiental pela Universidade Norte do Paraná. Tem experiência na área de Recursos Florestais e Engenharia Florestal.

\section{Marisa Pereira Matt}

Engenheira agrônoma graduada pela Universidade Federal de Rondônia. Tem experiência na área de Agronomia.

\section{Marlos Oliveira Porto}

Graduado em Medicina Veterinária pela Universidade Federal de Viçosa. Mestre e Doutor na área de Zootecnia pela mesma instituição, com ênfase em Produção e Nutrição de Ruminantes, atuando principalmente nas áreas de produção de gado de corte, suplementação de bovinos em pastagens, avaliação de alimentos e alimentação animal, exigências nutricionais de ruminantes e produção de bovinos de corte em confinamento. Membro permanente do Programa de Mestrado em Ciências Ambientais da Universidade Federal de Rondônia/Embrapa. Membro permanente do Programa de Pós-Graduação em Sanidade e Produção Animal, da Universidade Federal do Acre/Universidade Federal de Rondônia/Embrapa. Participa como líder nos Grupos de Pesquisa em Tecnologias Agroambientais e Grupo de Pesquisa em Produção Animal e Aproveitamento de Resíduos. Atualmente é professor Adjunto IV da Universidade Federal de Rondônia - UNIR, e Coordenador do Setor de Bovinocultura de Corte.

\section{Odair Queiroz Lara}

Engenheiro Agrônomo formado pela Universidade Federal de Rondônia UNIR. Trabalha com Pecuária de corte e de leite na região de Espigão do Oeste - RO 


\section{Rosalvo Stachiw}

Graduado em Química pela Universidade Federal de Mato Grosso, atuou na indústria de alimentos em 2001/2002 no controle de qualidade, Mestre em ciências (química analítica/quimiometria), no CEFETPR, e doutorado em Ciências na Universidade Tecnológica Federal do Paraná. Tem experiência na área de Química Geral, Analítica, Orgânica, Inorgânica, Processos Químicos Agroindustriais, Química Ambiental, Química Verde, Tratamento de Água e Esgoto e Tratamento de Efluentes Industriais e Resíduos Sólidos Urbanos, atuando principalmente nos seguintes temas: Xisto, Recursos Hídricos, Biodiesel, Solos, Resíduos em geral. Atualmente é professor de química da Universidade Federal de Rondônia, nos cursos de Engenharia Florestal e Agronomia, ministrando aulas de química geral, analítica e orgânica. É revisor e editor de revistas científicas e orientador do curso de mestrado no Programa de Pós-graduação em Ciências Ambientais da UNIR e do Mestrado em Agroecossistemas Ambientais da UNIR. Membro da Câmara Técnica de Ciência e Tecnologia do Conselho Nacional dos Recursos Hídricos. É coordenador do Laboratório de Análise de Águas.

\section{Sheyla Ariene Ramos de Campos}

Tem experiência na área de Enfermagem, com ênfase em Enfermagem de Saúde Pública.

\section{Thaís Rabelo dos Santos}

Possui graduação em Medicina Veterinária pela Universidade Estadual Paulista Júlio de Mesquita Filho, mestrado e doutorado em Medicina Veterinária na área de concentração Patologia Animal, pela Universidade Estadual Paulista Júlio de Mesquita Filho. Possui experiência na área de Medicina Veterinária, com ênfase em Medicina Veterinária Preventiva, área de concentração Parasitologia Veterinária, atuando principalmente com Protozoologia Parasitária Animal e helmintos de importância veterinária. 


\section{Thassiane Telles Conde}

Graduada em Química pela Faculdade de Educação e Meio Ambiente, Mestre em Ciências Ambientais pela Universidade Federal de Rondônia, Doutoranda em Agronomia pela Universidade Estadual Paulista. É professora do Ensino Básico, Técnico e Tecnológico do Instituto Federal de Rondônia, atuando nas áreas de Ensino, Pesquisa e Extensão. Leciona as disciplinas de: Química Geral, Química Orgânica, Metodologia do Ensino de Ciências I e II. As principais linhas de pesquisa são: Recursos Hídricos e Metodologia do Ensino de Ciências/Química.

\section{Tiago Gyovani de Melo Balbino}

Engenheiro Agrônomo pelo Serviço Nacional de Aprendizagem Rural SENAR/RO. 
